UNIVERSIDADE DE SÃO PAULO

FACULDADE DE FILOSOFIA, LETRAS E CIÊNCIAS HUMANAS

DEPARTAMENTO DE LETRAS CLÁSSICAS E VERNÁCULAS

PROGRAMA DE PÓS-GRADUAÇÃO EM ESTUDOS COMPARADOS DE

LITERATURAS DE LÍNGUA PORTUGUESA

Damares Barbosa

\title{
Roteiro da Literatura de Timor-Leste em Língua Portuguesa
}

(VERSÃO CORRIGIDA)

São Paulo

2013 
FACULDADE DE FILOSOFIA, LETRAS E CIÊNCIAS HUMANAS

DEPARTAMENTO DE LETRAS CLÁSSICAS E VERNÁCULAS

PROGRAMA DE PÓS-GRADUAÇÃO EM ESTUDOS COMPARADOS DE

LITERATURAS DE LÍNGUA PORTUGUESA

\section{Roteiro da Literatura de Timor-Leste em Língua Portuguesa}

Damares Barbosa

Tese apresentada ao Programa de PósGraduação em Estudos Comparados de Literaturas de Língua Portuguesa, do Departamento de Letras Clássicas e Vernáculas da Faculdade de Filosofia, Letras e Ciências Humanas da Universidade de São Paulo, para a obtenção do título de doutor e $\mathrm{m} L$ e $\mathrm{t} r \mathrm{a}$.

Orientador: Prof. Dr. Helder Garmes

São Paulo

2013 
Para meus filhos

César Augusto e Sophia Maria da Glória, amigos inseparáveis, dádivas concedidas... 


\section{Agradecimentos}

Em primeiro lugar, agradeço a Deus, que tem guiado os meus caminhos.

Agradeço a meu pai, exemplo de vida, amor e carinho, que em tudo me ajudou.

Aos meus irmãos, companheiros de viagem, a quem devo muito.

Aos professores da USP, que fomentaram intelectualmente o meu trabalho.

Ao Prof. Dr. Helder Garmes, brilhante orientador e amigo leal, acima de todas as coisas, que, com sua generosidade, não poupou esforços para me alentar durante essa jornada.

À Profa. Dra. Regina Helena Pires de Brito, que generosamente dividiu comigo seus conhecimentos sobre Timor-Leste, tão apaixonadamente, e deixou-se descobrir como companheira e amiga.

Ao Prof. Dr. Benjamin Abdala Junior, que, durante os anos de curso, sempre esteve presente, sendo prestativo em todos os momentos. Agradeço-o também pela disposição em sugerir novos caminhos para esse trabalho durante o exame de qualificação.

À Profa. Dra. Vima Lia, que, com disposição, firmeza e brilhantismo, forneceu material e incentivo intelectual para a conclusão deste trabalho.

Aos professores doutores Fátima Bueno, Mário César Lugarinho, Rita Chaves, Tania Macedo e Émerson Inácio, por suas contribuições no decorrer do doutorado.

Agradeço à Mari e à Creusa, do CELP, pela amizade, a atenção irrestrita, o carinho e o afeto com os quais me receberam.

Aos funcionários do DLCV, da pós-graduação e da Biblioteca Florestan Fernandes, pela ajuda recebida.

Aos colegas da pós-graduação: Giselle, Débora, José, Daiane, Giu e Carol, que discutiram o meu trabalho.

À Eliana, dedicada colaboradora da Biblioteca da Casa de Portugal.

Ao Prof. Marcio Gagliato, que, entre São Paulo e Zaire, dispensou tempo para falar comigo sobre a sua vivência em Timor. 
Aos Professores Doutores Nilton Tadeu Queiroz Alonso e Magued El Gebaly, profissionais exemplares e ótimos amigos, por darem excelentes contribuições durante o doutorado.

À Profa. Dra. Thaís Montenegro Chinellato, por acompanhar minha jornada estudantil, discutindo os textos e as ideias, sendo sempre amiga e companheira.

Ao Carisvaldo, que cuidou tão bem das crianças enquanto eu escrevia a tese.

À Erika Horigoshi, pelo excelente desempenho profissional e companheirismo no decorrer deste trabalho!

Em Portugal, agradeço a todos os professores, amigos e colegas, que gentilmente me acolheram: ao Prof. Doutorando Flávio Borda D’Água, pela ajuda e orientação em alguns pontos referentes ao histórico de Timor, à Profa. Dra. Ana Luísa Vilela, que, em Lisboa, se portou como profissional impecável e me apresentou ao Prof. Barbedo de Magalhães, guiando-me também amistosamente em Évora, para a conclusão da minha pesquisa.

À Profa. Dra. Claudiany Pereira, do Rio Grande do Sul, que, entre Lisboa e Guiné, teve tempo para uma breve conversa comigo sobre Timor.

Ao Prof. Moisés Fernandes, que explicou o conflito religioso em Timor.

À Ana, Maria e Isabel, funcionárias prestativas, que me auxiliaram durante a pesquisa na Fundação Mário Soares e "Por Timor".

Em especial, à Profa. Dra. Florbela Marante, que elucidou as questões referentes ao conflito e à resistência timorense, e como organizou o Museu da Resistência Timorense em Lisboa e Díli.

Ao escritor Luís Cardoso, que, em entrevista em Brasília e São Paulo, muito colaborou e sempre se prestou a auxiliar na compreensão sobre Timor e sua literatura.

Ao Prof. Luís Costa, que, estando em Lisboa, sempre auxiliou nas questões linguísticas e intelectuais do povo timorense.

Ao Prof. Doutorando José Carlos Adão, que, com gentileza e paciência, entre África, Portugal e Timor, generosamente me ofereceu sua dissertação e livros, deslindando questões políticas sobre Timor.

Ao Prof. Ms. Rodrigo More, com sua brilhante dissertação sobre a reconstrução de Timor. 
E aos meus filhos, que sempre estiveram ao meu lado durante a realização deste trabalho; a eles dedico esta tese. 


\section{Ficha catalográfica}

BARBOSA, Damares. Roteiro da Literatura de Timor-Leste em língua portuguesa. (2013) Tese (Doutorado) - Faculdade de Filosofia, Letras e Ciências Humanas da Universidade de São Paulo, São Paulo, 2013.

\section{RESUMO}

A presente pesquisa tem como escopo reunir e comentar a Literatura de TimorLeste em língua portuguesa, tendo como base seus principais representantes. Das lendas às narrativas de viagem, da poesia dos escritores politicamente engajados aos romances escritos na diáspora, o presente estudo procura identificar as principais questões que estiveram no horizonte dos timorenses em diferentes momentos de sua história, assim como delinear a imagem que 0 conjunto desses textos acabou por produzir de Timor na contemporaneidade.

Palavras-chave: Timor-Leste; diáspora; literatura de Timor-Leste

\section{ABSTRACT}

This research has the objective to gather and review the literature of TimorLeste in Portuguese, based on its main representatives. The legends to travel narratives, poetry politically engaged writers of the novels written in the diaspora, this study seeks to identify the key issues that were on the horizon of the East Timorese at different times in its history, as well as outline the image that all these texts eventually produced the Timor nowadays.

Keywords: East Timor; diaspora; East Timor literature 


\section{REZUMU}

Peskiza ida ne'e hakarak ho laran halibur no dada lia kona Literatura TimorLeste nian ho lia portugés, hili hanesan hun ninia saseluk importanti sira. Hosi knanoik to'o hakerek kona la'o dalan, dadolin hosi hakerek na'in sira ne'e be hala'o politika to'o romanse sira hakerek iha diaspora, istudu ida ne'e buka foti kestaun importanti sira ne'e be mosu iha timoroan sira nia hanoin iha tempu oioin iha sira istoria, hanesan mos taturik ilas ne'e be testu sira ne'e hotu hamutuk ikus mai haburas Timor iha tempu ohin.

Liafuan-xave: Timor-Leste; diaspora; literatura Timor-Leste nian. 


\section{Sumário}

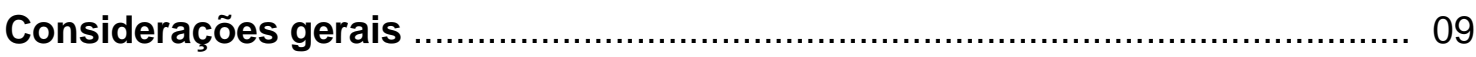

O presente trabalho: o estudo literário …….................................................... 15

\section{Capítulo 1 - Do descobrimento e das missões}

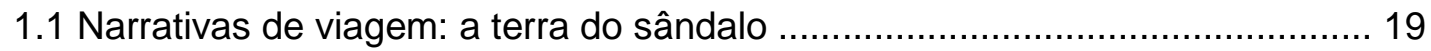

$1.2 \bigcirc$ aprendizado da língua portuguesa e as várias identidades timorenses ...... 34

1.3 A notícia escrita em Timor: imprensa em língua portuguesa ......................... 45

\section{Capítulo 2 - Da poesia}

2.1 Considerações sobre a poesia do Timor ................................................... 50

2.2. Alberto Osório de Castro: juiz e poeta ....................................................... 53

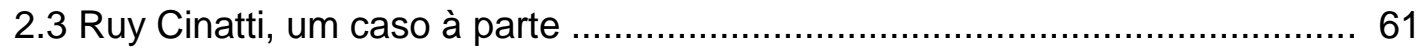

2.4 Independência política e literária .......................................................... 76

2.5. Literatura engajada: a poesia dos militantes ........................................ 81

\section{Capítulo 3 - Da prosa}

3.1 Considerações sobre a prosa do Timor ..................................................... 101

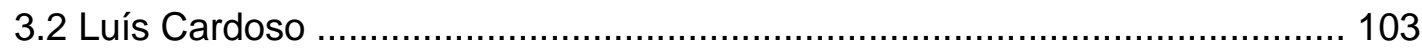

3.3 Outros autores: Ponte Pedrinha e Domingos de Sousa ............................. 123

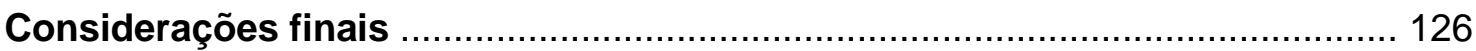

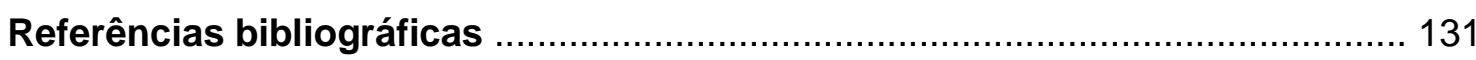

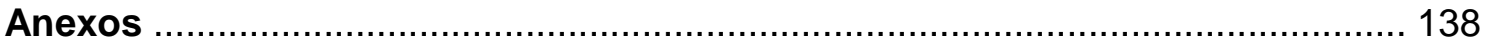


"Mesmo uma boa intenção não justifica a opressão da consciência própria e alheia”.

Doutor Miguel Vieira Ferreira 


\section{Considerações gerais}

A pesquisa empreendida tem como escopo analisar a literatura de Timor-Leste em língua portuguesa, tendo como base seus principais representantes conhecidos até a presente data. Das lendas às narrativas de viagem, da poesia dos escritores politicamente engajados aos romances escritos na diáspora, o estudo propõe-se a identificar as várias questões que se observam nos textos daqueles que escrevem literariamente sobre Timor-Leste em língua portuguesa, sobretudo nos textos daqueles que retratam, em suas obras, os usos e costumes do povo timorense, bem como situações vivenciadas durante a colonização portuguesa, a independência, a luta armada contra a Indonésia e a diáspora.

Em Timor $^{1}$, havia vários povos quando da chegada dos chineses e, depois, dos portugueses, com costumes, ritos e também línguas próprias. Embora o tétum fosse um idioma comum, mais usado para a conversação entre os vários povos, o português, ao ser introduzido, foi instituído como língua oficial.

A proposta é estudar a produção em língua portuguesa já existente naquele país, levada a cabo quer por timorenses, quer por aqueles que se identificaram fortemente com aquela localidade. Será necessário, contudo, recordar os motivos pelos quais a língua portuguesa foi definida como língua oficial, após a formação da Constituição de Timor-Leste, bem como entender o propósito do idioma na região e seu contexto político dentro do panorama internacional.

A ilha de Timor, na extrema Ásia, vizinha da Austrália, foi um dos pontos nos quais os portugueses se fixaram durante as navegações quinhentistas ao Oriente, tornando-se uma colônia portuguesa bem mais tarde, sem jamais ser

\footnotetext{
${ }^{1}$ Neste trabalho, será adotado o termo Timor ou Timor-Leste, considerando o contexto da palavra no decorrer do texto, tendo em vista que houve uma separação político-geográfica no final do século XVI, ratificada por meio de acordos políticos, dividindo a região entre Holanda e Portugal. Assim, a Holanda passou a dominar a região ocidental da ilha e Portugal exerceu 0 domínio da parte oriental, a partir de então denominada Timor-Leste.
} 
atribuído ao território status de colônia de povoamento; em princípio, ele servia única e exclusivamente para a exploração de especiarias, que motivaram a chegada das naus portuguesas ao seu litoral.

Poucos anos após a chegada dos navegadores portugueses, chegaram ao território timorense os religiosos, missionários que já estavam no Oriente, em Malaca. À época, Goa e Macau eram territórios coloniais portugueses e, portanto, as ilhas de Malaca, Molucas, Solor, Flores e Timor, também no Oriente, já estavam sob o domínio de Portugal, ou na rota por eles traçada para novas conquistas.

A partir da chegada dos missionários que estavam em Goa ao território timorense, o comércio de especiarias, já iniciado, foi intensificado e, por consequência, Timor passou a fazer parte da rota comercial entre Portugal, Macau e Malaca, assim como a Batávia. Nessa época, a língua portuguesa começou a ser propagada na região.

Fundamental para a língua portuguesa em Timor foi o papel da igreja católica, ao enviar missionários para lá. Assim como acontecera em outros territórios dominados pelos portugueses, onde o idioma se propagou a partir da presença dos missionários, da mesma forma, os textos em língua portuguesa produzidos em solo timorense chegaram até nós em razão da presença deles naquele local.

São dos missionários e navegadores enviados por Portugal àquele território os primeiros escritos encontrados em língua portuguesa que versam sobre Timor, dentre os quais os dicionários de tétum-português, elaborados pelos referidos religiosos, uma gramática da língua portuguesa e também as primeiras traduções das lendas antigas de Timor.

A exemplo da literatura latina, que teve seu início com as traduções a partir da língua grega, também a literatura timorense em língua portuguesa, em seus primórdios, recebeu as já citadas traduções das suas lendas narradas originalmente em tétum.

No que se refere à questão do território, para manter o domínio em Timor, Portugal passou a enviar administradores da Coroa à região, por conta dos embates havidos com os holandeses, que acabaram conquistando parte 
do território, e também com outros povos, tais como os jaus e os macaçares². Os escritos de navegadores que descreviam a ilha e também os de missionários que lá estavam, relatando os acontecimentos à realeza e aos membros do clero, em Portugal, propiciaram o surgimento do que podemos considerar, hoje, a primeira literatura timorense de língua portuguesa. Esses escritos relatavam o que se passava ali, descreviam as paisagens do local e narravam os costumes dos povos que habitavam a ilha. Timor, portanto, passou a ser conhecido e, ao mesmo tempo, compreendido, principalmente pelos missionários.

A língua portuguesa, introduzida à força pelos colonizadores, foi ali cultivada, sobretudo pelos religiosos, que, desejosos de conhecer o povo nativo, iniciaram o ensino da língua e, com ele, o das traduções já referidas. Esse ensino durou até a época do rompimento com Portugal, quando, após a invasão das tropas indonésias, os timorenses optaram pela língua portuguesa para a comunicação entre os militantes que defendiam a independência de seu país, transformando o idioma em um instrumento de luta para a resistência.

Ainda, é mister citar, mesmo que de maneira abreviada, os periódicos timorenses, explicando sua origem, qual o valor da imprensa local e seu funcionamento; por quem esses periódicos eram escritos, para quem eram escritos e por quem eram lidos.

Finalmente, a questão da identidade nacional, imposta ao longo do tempo aos timorenses, será abordada a partir da análise dos textos em prosa e poesia escritos por timorenses e também por escritores que viveram em Timor.

Para tanto, foi necessário, em primeiro lugar, uma pesquisa das obras literárias, a par da compilação feita por João Paulo Esperança em Um brevíssimo olhar sobre a literatura timorense. A seguir, foi necessário definir a noção de literatura de Timor-Leste e de literatura timorense, de acordo com a descrição de João Paulo Esperança, além dos estudos feitos pelos professores Artur Marcos e Ricardo Antunes.

\footnotetext{
2 Piratas provenientes da ilha de Jau e de Macaçar, na ilha de Celebes, respectivamente (SERRÃO, 2006:403-407).
} 
É a partir da matriz cultural das lendas que Timor vai passar a elaborar sua identidade literária ${ }^{3}$. Alguns estudiosos de Timor-Leste, quer historiadores, quer literatos, refletiram sobre a melhor forma de escrever a história literária daquele país. Ao ser constatada a importância do uso do idioma português para Timor-Leste, em seu contexto histórico, social e cultural, ao longo dos anos, era mister que os escritos reunidos fossem compilados, a fim de gerar um estudo literário, ainda que incipiente.

Artur Marcos, historiador português, explica a propósito:

A respeito daquilo que habitualmente se chama "Literatura", propriamente dita (de intenção artística verbal: poesia, romances, etc.), articulando uma consulta à bibliografia de Kevin Sherlock com a utilização de outras fontes e conhecimentos próprios - chegamos à conclusão de que um trabalho que visasse uma apresentação de Timor aos especialistas de Literatura, para que Timor surgisse nas disciplinas literárias como outros territórios do Mundo, deveria considerar $(A) 0$ talvez classificável como "literatura timorense de expressão portuguesa", mas também (B) a literatura oral, igualmente chamada "oratura", em idiomas dos grupos etnolinguísticos locais, $(C)$ a literatura que haja escrita nestes idiomas, ainda (D) as composições de timorenses em línguas não-timorenses e, quiçá, (E) a escrita de "malae sira", i.e. de "naturais de outros países", com temática de ou enredo em...Timor. (MARCOS, 1995:143)

Artur Marcos escreveu um dos primeiros estudos gerais sobre a cultura, a língua e a literatura de Timor-Leste. A divisão da literatura timorense por ele apresentada encontra divergências, se confrontada com outros autores, tais como João Paulo Esperança e Ricardo Jorge Antunes ${ }^{4}$.

Segundo Ricardo Jorge Antunes, linguista que viveu em Timor-Leste, existia uma elite timorense composta por auxiliares da administração portuguesa e seus filhos, bem como os militares de "segunda linha". A estes, o português era ensinado de maneira privilegiada. Dessa forma, como se há de

\footnotetext{
${ }^{3}$ Verificar, nos anexos desta pesquisa, o texto "A lenda do crocodilo", que reproduz uma das lendas mais famosas de Timor e comenta a importância dessa tradição para o povo daquela ilha.

${ }^{4}$ MARCOS, Artur. Timor timorense. Com suas línguas, literaturas, Iusofonia...1995.
} 
ver mais detalhadamente, surgiram os primeiros escritos em língua portuguesa, produzidos por autores não missionários.

Ricardo Jorge Antunes, em seu texto O que é Timor? Língua e literatura em Timor-Leste $(2007)^{5}$, aborda os caminhos percorridos por aqueles que escreveram em Timor e sobre Timor. Fala sobre a literatura de Timor, acrescentando que a nomenclatura "literatura timorense" serve apenas para os textos dos timorenses. Explica, ainda, o porquê da escolha do termo literatura timorense para os escritos dos autores nascidos no país:

Depois de uma viagem, superficial, sobre a literatura escrita com influência em Timor Lorosa'e, vejamos agora com alguma atenção a literatura de produção nacional. Desde logo há que fazer uma chamada de atenção: oficialmente, o país só existe desde 2002, mas aqui considero os escritores que se destacaram de algum modo, tomando como critério o terem nascido em Timor. Acredito que nem sempre este critério possa funcionar na perfeição para delimitar a literatura de um país, mas neste momento é 0 que me parece mais adequado (ANTUNES, 2007:13).

Antunes observa ainda que a escolha oficial da língua portuguesa em Timor-Leste estava ligada à questão da identidade cultural no país, questionando e discutindo em que medida tal identidade foi impulsionada pelos próprios timorenses ou pelos "outros" (japoneses, portugueses, indonésios). Faz também uma recapitulação dos textos produzidos em língua portuguesa por timorenses ou escritos sobre Timor, a par do que fora elencado por João Paulo Esperança. Este, por sua vez, ao escrever Um brevíssimo olhar sobre a literatura de Timor (2004), traça um resumido panorama literário de caráter geral em Timor-Leste, ressaltando a importância dos vários escritos durante cada momento histórico vivenciado pelo povo daquele país. Ele chama a atenção para o fato de que muitos dos referidos escritos elencados não foram assinados propriamente por timorenses, razão das seguintes considerações iniciais em seu texto:

Por que literatura de 'Timor' e não 'timorense'? É que não pretendo limitar me aqui aos autores nacionais, mas sim incluir também um

\footnotetext{
${ }^{5}$ ANTUNES, Ricardo J. O que é Timor? Língua e literatura em Timor-Leste. 2007.
} 
pouco daquilo que há para ler de naturais de outras paragens que tenham tomado Timor como tema literário. (ESPERANÇA, 2004:01)

Esperança ainda classifica a incipiente literatura de Timor-Leste, separando-a por completo da literatura oral e de tradição, da literatura puramente escrita, salientando sua evolução ao descrever e classificar os fatos históricos vivenciados no país. Ao tomar essa literatura em conjunto, o autor separa-a da seguinte maneira:

A época do colonialismo fez surgir um tipo de ficção a que chamamos hoje "literatura colonial", que na definição clássica de Pires Laranjeira é aquela que é "escrita e publicada, na maioria esmagadora, por portugueses de torna-viagem, numa perspectiva de exotismo, evasionismo, preconceito racial e reiteração colonial e colonialista (...)" Em Timor, um bom representante deste gênero é Caiúru, de Grácio Ribeiro. (...) Já integrado na corrente pós-colonial, e fortemente crítico dos males do colonialismo, destaco Corpo colonial (...) Um livro de sinal completamente oposto ao da literatura colonial é Uma deusa no inferno de Timor, de Francisco A. Gomes. Este livro pertence ao que poderíamos chamar "uma literatura de remorso" (...). (ESPERANÇA, 2004:2-4)

João Paulo Esperança também trata dos poetas engajados, em sua maioria dos que lutaram durante os anos da repressão indonésia, como integrantes da militância contra o regime de Suharto, ditador da Indonésia. Afirma Esperança, portanto, que são esses os primeiros timorenses engajados na luta pela independência de Timor-Leste. O autor, por fim, fala-nos da obra de Luís Cardoso e Ponte Pedrinha, escritores nascidos em Timor-Leste e representantes da prosa timorense na diáspora.

Tomadas em conjunto, as reflexões dos diversos intelectuais que se debruçaram sobre a literatura de Timor-Leste revelaram semelhanças nos aspectos classificatórios. À parte a literatura oral traduzida, que apresenta várias versões, sobretudo das lendas, as diversas fases da literatura em TimorLeste ou sobre Timor-Leste tiveram origem na vida histórica e social daquele país. Em linhas gerais, podemos dizer que essa incipiente literatura apresenta 
dois grandes blocos: um de caráter colonial; outro de caráter nacional e politicamente engajado.

\section{O presente trabalho: o estudo literário}

Diante do que foi exposto, podemos dizer que este trabalho adota o que Ricardo Jorge Antunes e João Paulo Esperança designam como Literatura de Timor-Leste, mantendo-se somente no âmbito dos textos escritos, e não da oratura, pois as lendas que mais tarde foram traduzidas serão apresentadas de forma breve.

Seguinte à cronologia histórica timorense, o presente trabalho optou por distribuir o conjunto de textos que formam a literatura de Timor-Leste nas seguintes categorias: Literatura de Viagem, Literatura das Missões, Literatura Engajada e, por fim, Literatura da Diáspora. É importante lembrar que, a despeito dessa breve divisão, existem outros escritos que não se enquadram nas citadas classificações, como, por exemplo, os da autoria de Ruy Cinatti. No entanto, os textos aqui tratados, de uma forma ou de outra, espelham as tradições e os costumes de Timor-Leste, pois foram escritos por timorenses e portugueses que viveram nesse território, ou que por ali se demoraram.

Por Literatura de Viagem, entende-se aquela produção inicial, os primeiros escritos de viajantes que descreveram as terras timorenses quando ali chegaram. Como acontecera no Brasil, assim que os portugueses pisaram em solo timorense, ali encontraram a população autóctone que, segundo o historiador Luís Filipe Thomaz, é do tipo vedo-australoide, de traços semelhantes aos dos aborígenes australianos e aos dos Vedás de Ceilão (THOMAZ, 2001:496). Ao chegarem a Solor e Timor, entre 1511 e 1516, partindo das ilhas de Malaca e Molucas, que já eram conhecidas das expedições portuguesas, os navegadores portugueses Francisco Serrão e António Abreu ficaram impressionados com o sândalo, "madeira muito abundante nestas ilhas (...) cuja quantidade superior encontrava bom mercado na China" (THOMAZ, 1994:548-593). 
É certo que, em princípio, Portugal não tinha interesse em colonizar Timor, nem foi impulsionado a realizar viagem até aquelas terras com esse propósito. A viagem às Ìndias e a Malaca, ou seja, ao Oriente, fez com que os portugueses tivessem notícias de uma terra além das Índias, que tinha como diferencial o sândalo, madeira perfumada e usada por diversos povos, com variadas finalidades. Os navegadores, inicialmente, passavam pelo Timor e nem sequer desciam das naus. Apenas, por meio de um bote, apanhavam a mercadoria e voltavam para suas naus. Dos escritos que, na atualidade, retratam a chegada do europeu a Timor e suas observações sobre o território, podemos destacar os da Suma Oriental de Tomé Pires, assim como trechos de citações dos navegadores. Mais recentemente, temos os livros Gentio de Timor, de Armando Pinto Correa, e A llha dos Homens Nus, de Paulo Braga, publicados em 1934 e 1936, respectivamente ${ }^{6}$. As descrições do século XVI são encontradas em pequenos trechos. Armando Pinto Correa faz uma descrição detalhada e um breve estudo sobre cada região da ilha de Timor, seus vários reinos e seus costumes; já o livro de Paulo Braga descreve a ilha e retrata as primeiras impressões que esta lhe causou.

Somente no século XVII, com a ida das missões a Timor, começou a se dar a fixação do europeu na ilha. Foram os missionários os primeiros europeus que verdadeiramente se preocuparam em conhecer Timor, sua gente e seus costumes. A Literatura das Missões consiste principalmente as traduções das primeiras lendas do tétum para o português, da compilação de gramáticas do tétum para a língua portuguesa, bem como de livros referentes à tradição oral do povo timorense.

Após a consolidação do comércio por parte dos portugueses na região, delegações administrativas são enviadas ao local. Em 1946, o engenheiro Ruy Cinatti é mandado a Timor-Leste e, ao se apaixonar pela terra timorense, escreve poemas sobre o povo nativo, tendo vivido muitos anos na região.

Já a Literatura Engajada teve como precursores Francisco Borja da Costa (1946-1975), Fernando Sylvan (1917-1993), Xanana Gusmão (1946-) e João Aparício (1968-), entre outros poetas, combatentes e membros da resistência timorense, que se prolonga no período da ocupação de Timor-Leste

\footnotetext{
${ }^{6}$ Destacamos alguns fragmentos das referidas obras como parte dos anexos desta pesquisa.
} 
pela Indonésia. A repressão indonésia, que gerou um dos maiores massacres da história da humanidade, ocorreu entre 1975 e 1999. A maior parte dos escritos dessa fase foi compilada durante esses anos. O próprio Xanana Gusmão escreveu o livro Mar meu (1998) na prisão, pois fora militante e líder político da frente de libertação em Timor-Leste.

Os romances escritos por timorenses que vivem fora de Timor-Leste perfazem outro capítulo deste trabalho e estão incluídos na Literatura da Diáspora. Os romancistas mais conhecidos e ora comentados são Ponte Pedrinha, pseudônimo de Henrique Borges, e Luís Cardoso de Noronha, muito divulgado na atualidade, o qual, desde sua primeira obra, sempre escreveu na diáspora. De Ponte Pedrinha, temos o romance Andanças de um timorense (1998). Do escritor Luís Cardoso, foram publicados os livros Crónica de uma travessia (1997), Olhos de coruja, Olhos de gato bravo (2001), A Última morte do Coronel Santiago (2003) e Réquiem para o navegador solitário (2007), O ano em que Pigafetta completou a circum-navegação (2013), até a presente data, e também o livro Colibere: um herói timorense (2007), de Domingos de Sousa, autor que reside atualmente no Brasil.

Para apresentar os textos históricos e as narrativas de viagem, situando Timor nos descobrimentos portugueses e, a seguir, as primeiras narrações sobre a ilha, serviram de base os trabalhos dos professores Luiz Felipe Thomaz, José Mattoso e Sanjay Subrahmanyam.

Além disso, embora não tenham sido diretamente empregadas neste trabalho, foram valiosas as informações coletadas no Arquivo Ultramarino, no Arquivo Diplomático e nos Arquivos da Torre do Tombo, tais como textos antigos e as primeiras inscrições sobre Timor.

As pesquisas realizadas na Biblioteca "Por Timor" e na Fundação Mário Soares serviram para melhor compreensão do tema "Resistência Timorense", no qual se enquadram os escritores engajados com seus poemas.

A prosa timorense, representada por Ponte Pedrinha, Domingos de Sousa e Luís Cardoso, que escreveram na diáspora, teve como pano de fundo os fatos históricos, as travessias e os deslocamentos. 
Em sua maioria, tais romances apresentam como cenário guerras e revoluções para descrever a história do povo de Timor e suas tradições.

Nesse aspecto específico, contextualizando as questões políticas e religiosas, os estudos recentes de Leonardo Sakamoto, Flávio Borda D’Água, José Carlos Adão e Márcio Gagliato e Rodrigo More, sobre a fase da reconstrução do país, foram de grande valia. 


\section{CAPÍTULO 1}

\section{Do descobrimento e das missões}

Deus quer, o homem sonha, a obra nasce

Deus quis que a terra fosse toda uma,

Que o mar unisse, já não separasse. Sagrou-te, e foste desvendando a espuma,

E a orla branca foi de ilha em continente, Clareou, correndo, até ao fim do mundo,

E viu-se a terra inteira, de repente,

Surgir, redonda, do azul profundo.

Quem te sagrou criou-te português.

Do mar e nós em ti nos deu sinal.

Cumpriu-se o mar, e o Império se desfez.

Senhor, falta cumprir-se Portugal!

(“O Infante”, Fernando Pessoa)

\subsection{Narrativas de viagem: a terra do sândalo}

Antes de discorrermos sobre como e em quais circunstâncias se deu a chegada dos portugueses ao solo timorense, há que se falar da terra propriamente e de seus habitantes, bem como da navegação praticada no Oriente antes do século XVI. Interessa-nos saber, ainda, como o território de Timor começou a ser habitado.

Segundo João M. Teles Cunha, em seu estudo Timor e o comércio do sândalo, desde o Paleolítico, começou a povoação do território, hoje conhecido como Timor, por parte de um tipo denominado vedo-australoide e, na época do Mesolítico, ali chegaram os chamados negroides ou malanésios e, em seguida, os proto-malaios (CUNHA, 1999:226). 
Apesar de fenícios e chineses terem chegado ao território timorense antes dos europeus, segundo relato do ano de 1522, feito por Antonio Pigafetta, geógrafo e cartógrafo italiano que fez viagens marítimas, e também segundo relatos anteriores de Fei Hsin, navegador chinês, que relatou, em 1436, suas viagens naquela região, a procura europeia pelo sândalo movimentou o território, a ponto de fazer com que os portugueses, que já haviam chegado à Insulíndia, empreendessem viagem a Timor para também explorar e comercializar essa planta.

Como veremos mais tarde, tal comércio por parte dos portugueses teve início com os missionários, pois o território era considerado insalubre, gerando medo até aos navegadores mais experientes. Quando os navegadores portugueses atingiram o território timorense, este não recebeu a denominação com a qual passou a ser designado. O primeiro nome escolhido para o país aparece em correspondência somente mais tarde.

Segundo relata o padre jesuíta Francisco de Sousa, no ano de 1511, por ordem de Afonso de Albuquerque, saiu de Malaca uma armada com os portugueses António de Abreu, Francisco Serrão e Fernão de Magalhães, estes últimos íntimos amigos, em três navios, com ordem de descobrir essas ilhas.

Conforme o autor Manuel Lobato, os missionários escreveram suas primeiras impressões sobre a ilha de Timor. Sobre os primeiros escritos, afirma esse autor terem sido da lavra dos religiosos da ordem de São Domingos e, da mesma forma, esclarece o que sucedeu com tais escritos:

As notícias que nos ficaram sobre os estabelecimentos de Sólor e Timor, são da autoria de Fr. António da Visitação, religioso dominicano. Fr. António, conhecendo a existência de uns cadernos, no convento de Goa, solicitou a sua remessa e assim as notas para Fr. António vieram nas naus de 1626, que acabaram por se perder no ano seguinte, nas costas da Biscaia. "Vindo em naus tão mal afortunadas, foram, porém, enviados a Lisboa (os cadernos) antes da perdição das naus ${ }^{7}$. (MARQUES, 2000:351-374)

\footnotetext{
${ }^{7}$ Assim explica Lobato ainda sobre o dominicano Frei Luiz de Sousa, que concorreu para a confirmação de tal evento: "Parece poder afirmar-se que essa circunstância permitiu reconstituir a história de tais possessões, no seu início, e com efeito, a Fr. Luiz de Sousa, com a sua História de S. Domingos se deve a conservação para a posteridade, dos elementos de estudo, sobre os quais se baseiam".
} 
A despeito do relato dos beneditinos, além do povo português, outros povos afirmavam ter conhecido as famosas terras orientais antes dos lusitanos. Como é sabido, a busca pelas especiarias moveu o mundo das navegações, bem como o afã de conquistar outras terras e dominar o mundo inteiro. As ilhas Molucas ficavam aquém de Timor e, como era de se esperar, pelo menos um relato anterior à data de 1511 foi encontrado nos livros, constatando a possível presença de outro europeu no limiar da descoberta de Timor:

O italiano Ludovico Varthena, o homem que afirmava ter sido o primeiro europeu que pisara terras das chamadas ilhas das especiarias, visitou a corte portuguesa. Com efeito, segundo a autoridade do escritor Henri Cordier, este italiano esteve nas Molucas no ano de 1504: ..."Il donne a une d'elles, sans doute à celle de Ternate ou Tidor, le nom du groupe entier, Monarch-Molucas" ${ }^{\prime 8}$ (LOBATO, 2000:61)

Quanto ao povoamento inicial das ilhas, conforme Lobato, embora exista incerteza, há o reconhecimento de que os chineses, na Idade Média, tenham sido os descobridores das especiarias, que foram levadas da Índia para a Pérsia e, em seguida, para a Europa. Dentre os viajantes europeus que empreenderam essa viagem, estão os seguintes nomes: Juan Serrano, Duarte Barbosa e António Pigaffeta, que era comentador de Fernão de Magalhães. Estes, certamente, visitaram as Molucas e estão inscritos nos livros históricos, com as respectivas cronologias de navegação, pelos historiadores portugueses.

Para melhor entendermos como Timor era visto pelos portugueses desde o princípio, não é necessário empreender uma pesquisa aprofundada sobre as navegações e a expansão marítima. Contudo, um breve conhecimento do contexto da chegada dos portugueses em Timor auxilia-nos, e muito, ainda que em termos geográficos, a olhar para questões propostas e analisadas no decorrer deste trabalho.

\footnotetext{
8 "Ele dá a uma delas, sem dúvida àquela de Ternate ou Tidore, o nome do grupo inteiro, Monarquia-Molucas" (tradução nossa).
} 
O primeiro contato dos portugueses com a Índia foi feito via terrestre em 1487, pelo escudeiro Pero de Covilhã, que falava árabe. A primeira viagem dos portugueses à Índia se deu em 1498, com Vasco da Gama (BOXER, 2005:4954). A importância dessa viagem, após o início das navegações, foi grande por encetar dois aspectos: o primeiro aspecto seria o mistério que envolvia tal campanha, pois alguns comerciantes em Portugal não desejavam que a Coroa estabelecesse comércio de especiarias diretamente com as Índias, e o segundo aspecto envolvia a questão religiosa, ou seja, o conflito direto entre a cristandade e $\mathrm{o}$ islão, pois havia a identificação do local como muçulmano (SUBRAHMANYAM, 1993:81).

Mais precisamente, a viagem de Vasco da Gama, segundo o historiador indiano Sanjay Subrahmanyam, foi uma viagem de fato misteriosa e seu início se deu antes de 1498:

A armada de Vasco da Gama deixou efetivamente o estuário do Tejo a 08 de julho de 1497, e chegou ao Cabo da Boa Esperança a 19 de novembro, mas só atingiu Calicute, o seu verdadeiro destino a 20/21 de maio de 1498. (SUBRAHMANYAM, 1993:80)

A partir daí, Portugal passou a navegar além das Índias e partiu para a conquista das terras do Extremo Oriente. Essa primeira fase das navegações durou até 1505, quando D. Francisco de Almeida foi nomeado primeiro vice-rei da Ásia Portuguesa.

Ora, os motivos religiosos colocados pelo historiador indiano sobre um possível conflito latente entre mundo ocidental e mundo oriental já estavam presentes. Contudo, a conquista do Oriente fundava-se de fato na busca pelas especiarias e por novas terras, a fim de aumentar o império colonial português. Essa segunda questão é retratada por dois autores de maneira complementar. Carmo Salazar Ponte, em seu livro Oliveira Martins - A história como Tragédia (1998), faz um estudo sobre a obra de Oliveira Martins e, com propriedade, analisa a obra do historiador, discorre sobre o império marítimo e define o papel do mar no imaginário português, assim o descrevendo: 
O mar na História de Portugal é-nos apresentado como uma entidade medonha; antes do começo da expansão marítima, por representar 0 desconhecido, e depois, devido à devastação que causou com os naufrágios e sofrimento humano e moral ao minar a vocação tradicional da nação, que é a rural. Deste modo, torna-se num símbolo de duas faces, que serve para ilustrar a fama alcançada por Portugal no seu domínio dos mares e o processo posterior de decadência que esse mesmo domínio desencadeou. O mar na sua função destruidora está intimamente ligado à loucura, no sentido em que o povo português perdeu a sua razão, quer pelos seus efeitos corruptores da riqueza acumulada ou porque abandonaram as suas terras para se entregarem à grande aventura do Oriente. (PONTE, 1998:108)

O mar é, portanto, demonizado no imaginário português e associado, sempre, às conquistas.

Também Charles R. Boxer, ao retratar as conquistas e o expansionismo marítimo, aborda, com clareza, o tema religioso, ao dissertar sobre o mito do sebastianismo. Fala sobre a mística sebastianista como um fator importantíssimo desde seu surgimento e que, a seu tempo, impregnou-se na alma portuguesa de tal forma que se tornou uma crença. Essa crença, portanto, fez com que seus adeptos se portassem como os escolhidos para propagar o cristianismo e aumentar o império português. Ao discorrer sobre a origem e a consolidação do mito do Sebastianismo em Portugal, Boxer aborda e aponta tal mito como um "messianismo" baseado na Bíblia e assevera ser essa crença a base do nacionalismo que impulsionou o povo português a conquistar outras terras e outros povos, com vistas à evangelização do mundo:

Os portugueses, que foram os pioneiros da expansão da Europa, e seus sucessores, sem dúvida fruíram, durante três séculos, dessa convicção em alto grau - e talvez num grau maior do que qualquer outra nação, na opinião de alguns observadores estrangeiros. A certeza de que Deus estava do lado deles, e de que podia intervir, e intervinha, diretamente a seu favor, foi certamente um fator importante na conquista e manutenção de Ceuta, assim como nas viagens de descobrimento e conquista que se seguiram. Quando a crença de que eram o povo escolhido por Deus para a expansão da fé foi reforçada pela popularização da lenda de Ourique e pelas correntes sebastianistas e messiânicas posteriores, o resultado foi um nacionalismo de durabilidade e firmeza excepcionais. Esse nacionalismo exaltado ajuda a explicar por que os portugueses conseguiram manter uma parte tão grande de seu precário império marítimo por tanto tempo, e por que se mostram tão relutantes em renunciar a qualquer parcela dele hoje em dia, tanto em relação às 
colônias economicamente viáveis (Angola, Moçambique) como às outras (Goa, Guiné). (BOXER, 2005:389)

Sobre as navegações portuguesas a Timor, em seu livro De Ceuta a Timor (1994), Luiz Filipe Thomaz faz um apanhado geral da trajetória portuguesa e afirma que, após a conquista de Malaca, em 1511, com a abertura dos mares da Insulíndia, os portugueses chegaram a Timor. A Malaca eles passaram a fazer visitas regulares, pois, embora houvesse comércio estabelecido de outras especiarias entre as regiões de Malaca, Macau e Timor, a China, que era o maior consumidor de sândalo, os portugueses tomaram a iniciativa de organizar viagens para buscar o produto em solo timorense, onde ele era produzido.

De fato, Malaca, que era um reino muçulmano, manteve frequentes relações comerciais com Timor nos séculos XV e XVI e, a partir de informações dos malaios que estavam nas embarcações dos portugueses, estes encontraram o território timorense entre 1514-1515 (SERRÃO, 2006:398).

O domínio do estreito de Malaca passa, assim, para a mão dos primeiros europeus que chegaram àquelas paragens, sendo Cingapura, no extremo sudeste do estreito, a chave de entrada de toda a navegação tradicional dos mares do Leste.

À época, os comerciantes de Malaca já estavam em contato com as Molucas e, possivelmente, com a llha de Timor, por causa da existência do sândalo naquelas terras. Já Damião de Goes afirma que António de Abreu dirigiu-se às Molucas em três naus, juntamente com Francisco Serrão e Simão Bisagudo, levando João Freire como feitor e Diogo Borges como escrivão. A tripulação compunha-se de 120 portugueses, além do pessoal de navegação. A armada deixou Malaca em fins de dezembro de 1511, pelo que se deduz ter sido realizada a descoberta em 1512 (SERRÃO, 2006:398).

Sobre um dos mais antigos documentos a tratar sobre a ilha de Timor, temos a seguinte descrição, no códice CXV)/2-1 da Biblioteca de Évora: 
A fortaleza de Sólor está sita em uma ilha deste nome que fica quatrocentas léguas de Malaca, em altura de oito graus e quatro minutos da banda sul, foi mandada fazer pelo governador Manuel de Sousa Coutinho (1588-1591) [...] Nas fazendas para veniagas e comércio, não as há mais que na ilha de Timor, que está trinta léguas de Sólor, gram cópia de um pau cheiroso, mui estimado em todo este Oriente, que chamam sândalo, porque o vão buscar de muitas partes, e particularmente da China, como em seu lugar se dirá e do macassar onde também vão os holandeses. O dito sândalo há no mato da dita ilha [...]. (p.78-80)

É a partir daí que começam a chegar relatos em língua portuguesa sobre o local. Aqui, portanto, são inseridos os textos escritos durante as viagens, 0 que se sabia sobre Timor, como os portugueses viram primeiro a llha e como esta foi relatada àqueles que enviaram as navegações. As primeiras impressões, portanto, constam desse período e, a partir dos primeiros relatos e mapas desenhados pelos cartógrafos, Timor passou a ser descrito e conhecido, também, no mundo ocidental.

Os primeiros relatos dos quais se têm conhecimento foram escritos por chineses que já conheciam o local ${ }^{9}$. No entanto, não existem traduções desses textos. A primeira referência ao comércio em Timor foi feita em 1436, por Fei Hsin, navegador chinês que explorava a região em busca de especiarias. Há uma versão de Manuel Lobato que afirma não haver qualquer registro do primeiro contato dos portugueses com Timor ${ }^{10}$.

Os escritos chineses, portanto, são os que relatam inicialmente a existência de diversos males nas ilhas de Timor, a ponto de as navegações chinesas ancorarem a alguns metros da ilha, mandando botes para recolher a mercadoria e seguir viagem. Assim foi com os portugueses. Não havia necessidade de fixar a permanência portuguesa no local para realizar a exploração do sândalo.

\footnotetext{
9 "A China exerceu na região uma influência vaga e indirecta desde a época dos Chou (1150221 a.C.), notando-se ainda hoje na arte popular de alguns povos traços longinquamente relacionados com o chamado 'estilo Chou tardio', cuja influência se sobrepôs às das civilizações megalítica e de Dong-Son. A presença dos Chineses em Timor, em busca do sândalo, está atestada desde o século XV; desde o início do século XVIII que há referências a comerciantes chineses estabelecidos na terra, em número sempre crescente; apesar disso a influência cultural chinesa é irrelevante." (THOMAZ, 1994:593)

${ }^{10}$ Manuel Lobato, em Timor nos Descobrimentos e na Cartografia (1992), afirma não haver registro do primeiro contato dos portugueses em Timor, porém insere em seu livro uma série de fragmentos e trechos das poucas descrições encontradas nos arquivos da Torre do Tombo.
} 
O comércio de sândalo, cera e carapaças de tartaruga foi ficando mais intenso. No entanto, as descrições da ilha eram feitas a partir do barco. $\mathrm{O}$ comércio entre javaneses, chineses e samatrenses em nada mudou a situação da ilha que, após a chegada dos portugueses, tomou outra configuração. Embora alguns malaios $e$ javaneses tivessem se instalado na ilha $e$ possivelmente relatado sobre o local, Tomé Pires, boticário português que escreveu um relato de viagem intitulado Suma Oriental ${ }^{11}$ é quem faz a primeira descrição portuguesa da ilha de Timor, por volta de 1515, segundo Rui Manuel Loureiro:

(Os mercadores) levam lá sinabafos, panchavalizes, sinhavas, balachos, cotabalachos, que são panos brancos. Valem em Timor panos de Cambaia baixos, e por pouca mercadoria carregam os juncos de sândalos. É rica a viagem de Timor, (mas) é doentia. (Os navios) partem de Malaca na monção e tempo (em) vão a Banda. Dizem que entre as terras de Bima e Solor há pedras (i.e., baixios), e que se perdem (os) juncos, se não vão pelo canal, e isto será obra de meia légua onde há este perigo, e que é bom abocá-lo de dia. (PIRES, 1944:76)

Neste pequeno trecho da Suma Oriental, um compêndio com relatos de viagens que contém o maior número de informações sobre a Ásia marítima trazido à luz em Portugal apenas em 1978 por Armando Cortesão, Tomé Pires descreve o que há na terra, tais como os panos de Cambaia e as mercadorias, ressaltando, dentre elas, o sândalo. Ao relatar a viagem de Timor como doentia, Pires remonta aos primeiros escritos chineses, que asseveravam não ser possível permanecer muito tempo em terras timorenses, alegando que o local era insalubre.

Tomé Pires descreve o caminho para se chegar a Timor, de Malaca a Banda, e afirma que, devido aos perigos, é melhor que se chegue à terra timorense durante o dia.

Duarte Barbosa, em seu Livro do que viu e ouviu no Oriente, concluído em 1516 e publicado a partir de notas e traduções em 1812, na Coleção de

\footnotetext{
11 Tomé Pires, Suma Oriental, In: Onde Nasce o Sândalo - Os Portugueses em Timor nos séculos XVI e XVII, Ed. Armando Cortesão, p.76.
} 
Notícias para a História e Geografia das Nações Ultramarinas, faz uma breve descrição da ilha de Timor:

Indo mais ao diante, deixando estas ilhas de Java Maior e Menor, ao mar dela estão outras muitas, grandes e pequenas, povoadas de gentios e mouros alguns, dentre as quais está Timor, que tem rei e língua sobre si.

Nesta ilha há muitos sândalos brancos, que os mouros muito estimam na Índia e na Pérsia, onde se gasta muita soma dêles, e têm grande valia no Malabar, Narsinga e Cambaia.

As naus de Meca e Jaoa que aqui vêm por ele, levam por retorno machados, machadinhos, cotelos, espadas, panos de Cambaia e de Paleacate, porcelanas, continhas de cores, estanho, azougue, chumbo e outras mercadorias, com que carregam o dito sândalo, de mel, cera, escravos e dalguma pimenta que na terra há. (BARBOSA, 1946:211)

Ao descrever Timor como uma terra que tem rei e língua próprios, Duarte Barbosa discorre sobre os vários sucos e datos ${ }^{12}$, com seus régulos e liurais e também sobre a planta que já era comercializada pelos mouros e também outros produtos interessantes para comércio existentes na ilha, tais como o mel e a cera. Dessa forma, Duarte Barbosa introduz em seu texto alguns aspectos geográficos, como a localização da ilha, os produtos que as naus carregavam de lá e também a estrutura organizacional dos timorenses encontrada pelos portugueses, que permaneceu quase igual com a chegada destes.

O professor Artur Teodoro de Matos faz a descrição do modo de vida dos vários povos que habitavam Timor e focaliza a chegada dos primeiros missionários à ilha, ressaltando a peculiaridade do sistema. Conforme relata o autor, a organização social em Timor-Leste encontrada pelos portugueses já era bem complexa e, na região, imperavam dois povos, ou dois reinos: o dos Belos e o do Servião. Assim, constituído o nível hierárquico e suas chefaturas, segundo nomenclatura apresentada por Matos, em Timor existia a seguinte estrutura:

[...] um pequeno grupo de famílias formava a povoação e os chefes das povoações formavam a classe da baixa nobreza, timungões ou tumungos. O grupo de povoações formava o suco, chefiado pelo chefe

\footnotetext{
${ }^{12}$ Esses termos serão explicados adiante.
} 
do suco ou dato, que era um nobre. O suco é a unidade fundamental de organização social timorense. Vários sucos formam o reino ou regulado, sob a autoridade de um chefe invariavelmente designado nos antigos textos portugueses por rei; chama-se-Ihe em tétum liurai termo que passou também ao português. (MATOS, 2006:1)

Com os estudos realizados até o presente momento, entendemos que Timor-Leste atual, então, correspondia ao reino dos Belos, e o reino do Servião correspondia ao território restante, o Timor indonésio. A organização encontrada, no entanto, era constituída de famílias e grupos, com uma estrutura hierárquica própria. Com a chegada dos portugueses e dos primeiros missionários, houve uma aproximação destes com os liurais.

Os missionários, ao tentarem se aproximar dos povos em Timor, procuraram não menosprezar ou coibir a cultura nativa, pelo contrário, a forma de aproximação utilizada contemplava a assimilação dos costumes por parte de ambos os lados. Assim, estreitados os laços, os liurais ganharam determinado poder, quando enfim a parte leste de Timor foi oficialmente dominada pelos portugueses.

Desde a instalação dos jesuítas na Insulíndia, o que se deu a partir de 1546, existiram missões em Macaçar e Maluco fundadas pela mesma ordem religiosa. Somente em 1559, os jesuítas organizaram expedições para evangelizar Solor e Timor. O convento fundado na localidade serviria de fortaleza contra os ataques das redondezas. De fato, os religiosos precisavam se proteger de outros povos que tentavam atingir as possessões que eram então evangelizadas. Contudo, os referidos ataques serviram para assentar a presença portuguesa de religiosos, quer dominicanos, quer jesuítas. Assim, a Coroa Portuguesa passa a administrar a ida dos religiosos, tornando o domínio de Portugal mais eficaz na região:

O enraizamento da presença portuguesa em Timor não se deve, porém, aos comerciantes mas aos missionários. O primeiro de que há notícia certa foi o franciscano Fr. António Taveira, que em 1556 converteu numerosos nativos. Em 1561, o primeiro bispo de Málaca, D. Frei Jorge de Sta. Luzia, dominicano, enviou para a zona quatro dominicanos que se estabeleceram na ilha de Solor; daí irradiou, agora de modo sistemático, a acção missionária para as vizinhas ilhas de Adunara, 
Flores, Savu e Timor [...] Para defender dos mouros jaus e macaçares o seu convento de Solor, os dominicanos construíram um forte; escolhido inicialmente pelos religiosos, o seu capitão começa no fim do século $\mathrm{XVI}$ a ser nomeado pelo vice-rei da Índia ou pelo próprio rei. (THOMAZ, 1994:594)

Com isso, naturalmente, os religiosos granjeavam a confiança entre os nativos e, dessa forma, a evangelização e o ensino da língua portuguesa foram, simultaneamente, tomando forma. No entanto, os religiosos só se fixaram na região em 1633, com Frei Cristóvão Rangel, que se estabeleceu na província dos Belos em Timor. Outras religiões, tais como o budismo e o hinduísmo, foram propagadas na região da Ásia Oriental.

Em Timor, os primeiros a aceitar o catolicismo foram os aristocratas, antes da chegada do primeiro governador português, efetivamente, em 1702, provavelmente como forma de ampliar os contatos, tendo em vista as negociações comerciais. Matos descreve essa ocupação como sorrateira, promovendo a assimilação dos ditames portugueses por parte dos timorenses:

Não se sabe exactamente de quando data o costume dos régulos que se convertiam ao catolicismo se declararem vassalos del-rei de Portugal; mas, seja como for, é claro que antes do terceiro quartel do século XVII tal vassalagem, a existir, era sobretudo simbólica e honorífica, pois continuava a não haver qualquer autoridade portuguesa permanente em Timor. (MATOS, 2006:5)

A sociedade portuguesa no Oriente, retratada por Sanjay Subrahmanyam, em seu O Império Asiático Português, 1500-1700, salienta as relações existentes nos territórios portugueses no Oriente. Assim, o autor descreve como os portugueses, em suas colônias, assimilavam a parte cultural dos nativos e, sobretudo, procuravam estabelecer alianças com os "nobres" e mais "destacados" da região, a fim de se fortalecer contra ataques, principalmente por parte dos holandeses, que tentavam também dominar a região e, consequentemente, arrebatar comercialmente os produtos explorados pelos portugueses.

Os missionários que ensinavam o idioma português aprendiam também o tétum, para se fazer entender pelos nativos da região. Por meio desses 
missionários, as primeiras traduções do tétum para o português são elaboradas, assim como os trabalhos de compêndios gramaticais. Ainda assim, apenas por volta de 1890, surge o primeiro Dicionário Português-Teto, de Sebastião Aparício da Silva, e, em 1907, o de Rafael das Dores, Dicionário Teto-Português.

Embora a Coroa Portuguesa nomeasse seus administradores para Timor, os régulos governavam seus respectivos reinos junto com os religiosos dominicanos, que exerciam grande influência sobre os nativos da região. De certo modo, a situação era cômoda para os portugueses que, assim, detinham o poder administrativo e religioso na região.

Contudo, em meados do século XVII, Malaca, que estava em declínio comercial, é conquistada pelos holandeses, que, até então, continuavam pelejando contra os portugueses para dominar as terras da região. O reino do Servião passa para o domínio holandês, exceto Oé-Cussi e Ambeno, que se tornam um enclave português na região. Timor, em sua parte ocidental, passa a ser definitivamente colonizada pelos holandeses.

É interessante ressaltar como se deu a colonização holandesa na região. Conforme estudo de Kabengele Munanga e Carlos Serrano, em $A$ revolta dos colonizados, citando o historiador Panikkar:

A Holanda, como escreveu o historiador Panikkar, era a única nação colonizadora europeia que jamais pensou em assumir qualquer responsabilidade moral ou legal para com sua colônia e que reduziu todo um povo à condição de bestas de carga. Desprovidos tanto do ardor espiritual dos portugueses e daquele sentimento de missão cultural reivindicado pelos franceses, os holandeses, segundo o mesmo autor, aferravam-se a um sistema de exploração pura e simples, que desprezava completamente 0 bem-estar dos povos reduzidos à servidão. (MUNANGA, 1995:45)

Sobre o método de colonização utilizado pelos holandeses, também se pronuncia Geoffrey Hull (2001). Ele descreve como se deu a colonização holandesa na Indonésia, que, mais tarde, influenciou o domínio dos indonésios em Timor-Leste. Essa comparação é feita e analisada, contextualizando as 
influências holandesa e portuguesa em suas respectivas colônias, à época, quanto à imposição cultural, linguística e religiosa, como observa:

No estudo da história mundial são bem conhecidas as diferenças entre os modelos de colonialismo holandês e português. $O$ que qualquer pessoa pode observar é que o colonialismo português e holandês produziram tendências opostas nas terras colonizadas. Sem querer simplificar este tema tão complexo, é possível afirmar que os holandeses estavam pouco interessados (pelo menos ao nível político) em se misturar com os povos indígenas. Os holandeses tinham pouca motivação para impor a religião calvinista aos seus súbditos. Não fazia parte dos seus projectos obrigar os indígenas a aprender o idioma holandês (na sua vasta colónia os holandeses aprenderam eles mesmos o malaio, e encorajaram o seu uso em todos os sectores). (HULL, 2001:35-36)

Hull estabelece, de maneira evidente, a estratégia dos holandeses de excluir os indígenas da sua cultura, a fim de manter sua hipotética superioridade racial perante os nativos. Também ressalta o que ocorreu ao término do domínio holandês na Indonésia: "Quando os holandeses saíram de vez da Indonésia, a sua influência sobre as línguas e culturas locais era ainda bastante superficial" (HULL, 2001:36). Em contrapartida, o autor afirma que os portugueses sempre tiveram como objetivo a assimilação das populações por eles conquistadas e acrescentadas ao seu império e, que, em Timor, como nas outras colônias, os casamentos mistos entre as raças eram comuns (HULL, 2001:36).

Geoffrey Hull demonstra, assim, a intenção dos portugueses de converter ao catolicismo a população da colônia, salientando que tal conversão não foi forçada, como ocorrera em Malaca e Goa, pois, em Timor, houve aliança entre os líderes nativos e os colonizadores:

Os portugueses chegaram à ilha de Timor com a finalidade - embora não totalmente realizada durante o período colonial - de converter toda a população ao catolicismo. Embora seja de notar que a conversão não foi forçada (como havia sido em Goa e Malaca), a maioria dos régulos timorenses aceitou o baptismo, recebendo nomes portugueses e títulos aristocráticos. Em muitos reinos a bandeira portuguesa tornou-se um lúlic (objeto sagrado), guardado e adorado em casas sagradas. (HULL, 2001:36) 
A colonização portuguesa em Timor, comparada aos métodos de colonização utilizados pelos holandeses, é, muitas vezes, considerada arcaica e negligente no que se refere à modernização bélica e mesmo aos propósitos de civilização. Sobre a disputa do território entre portugueses e holandeses em Timor, Maria Johana Schouten, em seu texto A prática de um ideal "civilização" e a presença colonial portuguesa em Timor, escreve:

A soberania sobre o território, que havia sido fixada nos documentos oficiais pertencentes ao tratado entre Portugal e Holanda, teria ainda de ser conquistada na prática. Não era uma tarefa fácil para os portugueses impor a sua autoridade às unidades políticas timorenses, tornando-se ainda mais difícil a partir de medidas impopulares, especialmente na tributação. (in SILVA, 2007:31)

Os religiosos portugueses publicaram compêndios e livros referentes ao ensino do tétum e do português. Para finalizar esta introdução à presença dos portugueses em Timor-Leste, destacamos, segundo anotações do padre Artur Basílio de Sá, em seu livro Textos em teto da literatura oral timorense (1961:21-22), algumas publicações realizadas por parte dos missionários portugueses que tomaram conhecimento do idioma tétum e demais idiomas da região:

Pe. Sebastião Manuel Aparício da Silva

Catecismo em tétum da doutrina cristã. Macau, 1885

Dicionário português-tétum. Macau, 1889

Pe. Manuel Maria Alves da Silva

Método para assistir à missa em galoli. Macau, 1888

Noções de gramática galoli. Macau, 1900

Compendio (em galoli) de orações quotidianas...Macau, 1902

Catecismo da doutrina christã em portuguez e galoli. Macau, 1903

Pe. Manuel Mendes Laranjeira

Cartilha tetum (1 e 2 parte), s/d

Catecismo tetum, s/d 
Pe. Manuel Fernandes Ferreira S. J.:

Historia sagrada (em portugues e tetum)

Catecismo badac, s/d

Rafael das Dores

Dicionário teto-portugues. Lisboa, 1907

Pe. Manuel Patricio Mendes

Dictionario tetum-portugues. Macau, s/d

Catecismo ho Oração Ruma, $2^{\text {a }}$ edição. Lisboa, 1952.

Doutrina Badac, 2ª edição. Lisboa, 1952.

Sarani Sira Nia Surai.

Pe. Abílio José Fernandes

Método prático para aprender o tetum. Macau, 1937

Pe. Artur Basílio de Sá:

Notas sobre linguística timorense. Lisboa, 1952

Pe. Norberto Augusto Parada

Lasi Sarani. Lisboa, 1956. 


\subsection{Aprendizado da língua portuguesa em Timor-Leste e as várias identidades timorenses}

...este novo país viria a escolher como língua oficial o português, retomando, formalmente e por vontade própria, os antigos laços estabelecidos com Portugal e a língua portuguesa ao longo de mais de quatro séculos.

Nuno Carlos Henriques de Almeida

A literatura de Timor-Leste em língua portuguesa revela como Timor era e é visto por aqueles que elaboraram e ainda elaboram os textos sobre a região. Nesse olhar, merece destaque também a questão linguística, visto que o português não alcançou o status de língua materna em Timor-Leste, ainda que, nos dias de hoje, este seja o idioma oficial por força da Constituição. Da mesma forma, essa distinção é necessária, pois o português foi o idioma eleito para compor os textos e, principalmente, os escritos poéticos que foram a primeira manifestação literária em língua portuguesa por parte dos timorenses.

Para bem entendermos o significado da língua portuguesa no país, é necessário que a questão seja verificada a partir de vários aspectos e prismas, a começar pelo motivo primordial da chegada dos portugueses a Timor, analisando como se deu a implantação do idioma naquela região, conforme descrito anteriormente.

De início, os portugueses que chegaram a Timor viam o território apenas como um prolongamento natural das ilhas Molucas e Malaca, territórios alcançados após a chegada às Índias. Após os primeiros contatos e a fixação inicial dos europeus na ilha, os religiosos portugueses provenientes das circunvizinhanças construíram um forte em Timor, a fim de obter proteção contra os ataques dos inimigos, jaus e macaçares. O comércio já existia, mas não havia, contudo, intenção de povoamento na região, apenas haviam encontrado mais um porto para explorar especiarias e continuar efetuando suas trocas, sem necessidade de encaminhar administradores para efetivar o domínio na região. Os religiosos também já realizavam a obra de catequização no Oriente e, consequentemente, chegaram a Timor. 
Portanto, segundo Luís Filipe Thomaz, no Oriente, a propagação da língua portuguesa se deu por três vias, a saber: por via de dominação política, por via do comércio e por via da missionação (THOMAZ, 2002:638). Contudo, há controvérsias quanto à principal via de implantação do idioma. Segundo o autor, ao contrário do que normalmente é apresentado por alguns estudiosos, não foi a via da missionação o principal meio para a implantação do português, em Timor. Thomaz afirma que, ainda que entre os cléricos o português tenha sido divulgado com certa rapidez, não o foi entre a população em massa.

Assinala o autor as fases de implantação, bem como a evolução histórica do português na ilha de Timor, da seguinte forma: da chegada dos portugueses, em 1514-1515 até 1556, a presença portuguesa foi meramente comercial e o português assim foi divulgado, como língua de comércio nos ancoradouros, apenas para efetuar troca de mercadorias. A seguir, houve 0 deslocamento dos religiosos, de Malaca para Timor. Devido à invasão holandesa em Malaca, os religiosos portugueses que lá estavam fixados passaram a residir em Timor. Em Larantuca, já havia um seminário para os filhos dos cristãos e, a partir da mudança da sede religiosa no Oriente, foi fundado, em 1738, um seminário em Timor. A fase política, que propiciou a divulgação do português em Timor, teve início com a chegada dos administradores, em 1702, e foi intensificada somente a partir de 1894, com o início do governo de José Celestino da Silva, que dominou efetivamente os reinos no interior da ilha e implementou uma ação mais burocrática, dentro do sistema colonial, na região. Houve um crescimento nos quadros do funcionalismo e, neles, começaram a penetrar poucos timorenses letrados (THOMAZ, 2002:638 e segs.).

De fato, embora a criação de escolas tenha se dado a partir da mudança da sede eclesiástica, vários outros fatores contribuíram para a propagação da língua portuguesa na região. Assim, a língua portuguesa começou a ser implantada, sem uma sistematização clara. A leitura e a escrita em língua portuguesa foram introduzidas pelos missionários, a fim de facilitar a catequização dos autóctones em Timor. Da mesma forma, o intuito de aprender o tétum por parte dos religiosos portugueses era o de se fazer aproximar dos liurais, chefes dos sucos e líderes religiosos em Timor. Essa aproximação, sem 
dúvida, deu frutos e a colonização estabeleceu-se a partir de uma rede de ações, que culminou com $o$ envio de administradores a Timor e, consequentemente, a nomeação de timorenses como funcionários da Coroa Portuguesa, à época em que Timor era território.

Com a necessidade de criação de escolas e seminários, onde a língua portuguesa passou a ser ensinada, sem dúvida a dinâmica administrativa local tomou outros rumos. Por isso, com o passar dos anos, em Timor, dois ofícios eram altamente valorizados na região, dentro da emergente sociedade local, e, portanto, num primeiro momento, os eleitos para exercer esses ofícios eram escolhidos pelas autoridades portuguesas. Essas profissões eram: professorcatequista e funcionário da administração.

Ao lado do português, o tétum recebeu várias modificações, conforme a chegada e a instalação de outros povos não originários de Timor. Quando da chegada dos portugueses em Timor, os vários povos que ali habitavam, além do tétum, comunicavam-se através das línguas regionais. O tétum, portanto, era usado apenas quando havia necessidade de comunicação entre habitantes de regiões distintas, e esse uso teve ampla aceitação:

A adoção do tétum como língua oficial da Igreja Católica de Timor foi em parte responsável por essa rápida propagação, adoção e efetiva utilização pelos timorenses. Dessa forma, o tétum funciona como língua veicular, como se pôde constatar, por exemplo, nos momentos em que pessoas de procedências diversas conversam informalmente, a língua utilizada é sempre o tétum - daí ser reconhecida como língua de coesão nacional. (BRITO, 2010:8)

Essa situação perdurou, mesmo com a intensificação da catequização dos missionários portugueses e o consequente ensino da língua portuguesa, pois esta, usada pela cúpula administrativa, era também utilizada para viabilizar a comunicação em Timor como colônia portuguesa. Esse histórico, transcrito por Regina Helena Brito, tem base no estudo de Artur Marcos:

Em O futuro da Língua Portuguesa em Timor Leste, Marcos aponta que, tendo a língua portuguesa chegado ao Timor somente no século XVI tornou-se uma das mais faladas na ilha. Convém, entretanto, destacar 
que, antes do período indonésio, em termos de difusão territorial e entre pessoas de línguas maternas diferentes, o tétum era usado em quase todas as situações cotidianas, enquanto a Língua Portuguesa se restringia à escrita ou às atividades relativas a determinados fins de ordem cultural ou administrativa. (Idem)

$O$ fato é que, do século $X V I$ ao $X X$, o ensino do português não foi intensamente programado entre os timorenses e o sistema de ensino não teve qualquer uniformidade. Mesmo com a criação de escolas e seminários, o tétum continuava sendo usado entre aqueles que pertenciam a regiões diferentes como a língua comum. Isso perdurou até a invasão indonésia.

À época da invasão indonésia, o ensino do idioma português foi proibido e seus falantes, em sua maioria, foram dizimados, restando, portanto, o contexto clandestino para a prática do idioma português. Dessa forma, ao ser formada a resistência timorense, passou a língua portuguesa a ser sinônimo de arma de combate, o que conferiu a ela o status de língua de resistência no período da luta armada e depois de língua oficial durante a redação da Constituição de Timor-Leste. Sobre o assunto, afirma Benjamin Abdala Junior:

Mais do que emblema da resistência do povo timorense, a atividade literária em língua portuguesa constitui hoje manifestação simbólica da forma como ele se imagina como nação, pela mediação de seus escritores. (Abdala apud GARMES, 2004:108)

Após a desocupação, por parte dos indonésios, do território timorense, ao cessar o conflito na região, houve a escolha dos parlamentares que redigiram a primeira constituição de Timor-Leste, para que a língua portuguesa se tornasse língua oficial, ao lado do tétum. Assim, o ensino da língua portuguesa foi retomado. Sobre este último aspecto, vale observar os estudos desenvolvidos sobre o ensino do português em Timor, sobretudo aqueles que enfatizam que o português não é a lingua materna dos timorenses ${ }^{13}$.

A trajetória da língua portuguesa em Timor-Leste, em princípio, pode ser considerada como uma estrada tortuosa, cheia de altos e baixos, e que, até o presente momento, não teve seu desfecho a contento. Linguistas e professores

\footnotetext{
${ }^{13}$ Sobre o tema, o estudo de Nuno Carlos Henriques de Almeida retrata a fundo as questões relacionadas ao ensino do português em Timor-Leste (2008).
} 
que estiveram em Timor-Leste participando do projeto para o ensino da língua portuguesa acreditam no progresso do ensino do idioma na região. Contudo, por questões políticas, outra vertente defende a não existência de futuro para o ensino do português, porquanto, durante os anos da ocupação indonésia, houve a proibição do ensino do português e a introdução da língua indonésia, juntamente com o idioma inglês; alguns argumentam que um desses idiomas deveria ser predominante na ilha por questões comerciais.

As lendas que contam as tradições de Timor foram traduzidas para o português e, a partir dessas traduções, Artur Basílio de Sá produziu um livro intitulado Textos em teto da literatura oral timorense (1961), que trata da chegada dos portugueses àquela ilha e conta as tais lendas. Ao traduzir do tétum para o português as lendas da tradição oral do Timor, a autor descreve como se deu, nos primórdios, o ensino da língua portuguesa e a política linguística em possessões portuguesas do Oriente e, sobretudo, em Timor.

Quando discorre sobre o início da colonização em Timor, a separação entre Timor Português e a parte pertencente à Indonésia, que fora colonizada então pelos holandeses, conclui que os fatores linguísticos tiveram influência sobre a atitute dos portugueses na região. Tendo em vista a diversidade linguística entre os povos no Timor, os portugueses utilizaram em Timor o mesmo procedimento adotado quando da chegada aos outros territórios, que mais tarde se transformariam em colônias. Após conquistarem as Índias e viajar às Molucas, o costume adotado pelos portugueses era usar a própria conversação em língua portuguesa com nativos indígenas do novo território. Dessa forma, os nativos assimilavam o idioma lusitano, quando ancoravam as embarcações. Como afirma o autor Basílio de Sá:

Aqueles varões assinalados, que andaram dilatando a Fé e o Império por terras desconhecidas, foram ao mesmo tempo os primeiros mestres do seu idioma entre estranhos povos de tão remotas paragens. Nas fortalezas, o grito às armas dos seus defensores era dado em português; nas feitorias, o diálogo do trato era feito em português; e até tratados de paz e amizade celebrados em nome de el-rei de Portugal com impantes soberanos do Oriente foram escritos em português. (SÁ, 1961:16) 
Basílio de Sá ainda fala sobre os intérpretes indígenas que acompanhavam o trabalho dos missionários. Tal serviço era prestado pelos línguas, como eram designados os auxiliares anônimos, intérpretes indígenas. Estes conheciam em certo grau a língua portuguesa e prestavam auxílio "às autoridades da soberania portuguesa ou aos apóstolos da evangelização" (SÁ, 1961:18). Basílio de Sá também nota que esses línguas seriam os primeiros indígenas a ocupar lugar de destaque junto aos portugueses na ilha:

Estes línguas, por suas funções, por seu contacto com representantes do Governo, por sua interferência nos actos oficiais das autoridades locais, e até por sua parcialidade, a troco de saguatis e camcés, nas contendas judiciais, foram ganhando, a pouco e pouco, certa preponderância entre os seus patrícios. (SÁ, 1961:18)

O autor também observa os fatores que dificultaram fixação e a expansão da língua portuguesa em Timor, conforme a política de colonização praticada pelos portugueses. Assim, embora houvesse a assimilação do modo de vida e também do idioma português, lembra o papel que, além do tétum, outras línguas locais cumpriam no cotidiano dos vários povos que habitavam Timor-Leste.

Ricardo Antunes, tendo realizado vasta pesquisa em território timorense, fala sobre a situação linguística local e argumenta que essa questão está intrinsecamente ligada à identidade nacional em Timor-Leste. Assim, justifica:

Todos sabemos que um dos mais importantes símbolos nacionais é a língua, pelo que, dúvidas na escolha da língua oficial, como as que se verificaram em Timor, envolvem questões de extrema importância ao nível do que podemos chamar Identidade Nacional. (ANTUNES, 2007:2)

Antunes afirma ainda que a língua é resultante de diversos fatores (econômico, social, cultural) e geralmente é um elemento que une a nação. No caso de Timor, cujo movimento independentista foi iniciado por uma elite que era conhecedora do idioma português, a escolha do português como língua oficial não se daria, se não fossem as circunstâncias que provocaram tal 
movimento e também pela colonização "cordial"14 promovida pelos portugueses.

Geoffrey Hull, professor australiano que viveu em Timor, analisa a língua e a cultura em Timor como fator de construção da identidade e também os resultados da influência portuguesa durante a colonização, sobretudo após a ocupação indonésia, anos mais tarde. Hull relata que o grande legado dos portugueses foi a criação e a implantação de aldeias católicas, o que deu força ao ensino do idioma português em Timor-Leste. Nesse mesmo trabalho, o autor descreve o dilema da nova geração em Timor, que questiona a utilidade do aprendizado da língua portuguesa:

Não nego, claro, que alguns jovens adultos, em Díli e Baucau, foram convencidos de que o inglês é a panaceia e o Português é uma carga inútil, prisioneira do passado, que Ihes foi imposta pela nostalgia dos seus pais. Mas quando ouço estas declarações, olho em volta e, geralmente, constato que esses jovens foram influenciados por "amigos" estrangeiros, falantes de inglês. Esta irresponsável propaganda anglófila, atenuou os efeitos da educação indonésia, cujo propósito era criar uma geração de timorenses na total ignorância da sua História e da sua cultura nacional, e instilar neles uma atitude crassamente materialista face à educação. (HULL, 1989:90)

Os estudos referentes ao ensino da língua portuguesa em Timor, por parte dos professores Geoffrey Hull, em seu texto Timor Lorosa'e. Timor Leste - Identidade, Língua e Política Educacional (2001), e também da professora Regina Helena Brito, com o seu Temas para a compreensão do atual quadro lingüístico de Timor-Leste (2010), merecem destaque neste trabalho. Vale lembrar que o linguista Geoffrey Hull vivenciou de perto o conflitos gerados pela busca da unidade linguística por parte vários povos que habitam a ilha.

A problemática gerada pelo dilema sobre a implantação de uma língua estrangeira como língua nacional, antes da redação da Constituição em Timor, está fundamentada no desejo de tornar o português língua oficial, por parte da velha geração em Timor, por motivos sentimentais e políticos. No entanto, em Timor, a nova geração, que aprendeu o bahasa indonésio e não vivenciou as

\footnotetext{
${ }^{14} \mathrm{O}$ autor refere-se à cordialidade portuguesa em contraposição ao massacre imposto pelas forças armadas indonésias, quando da invasão em 1974.
} 
agruras à época da ocupação indonésia, queria apenas o tétum como língua oficial e também a língua inglesa como idioma de conexão com o mundo ocidental:

\begin{abstract}
Infelizmente, quando Timor-Leste ganhou a sua independência, cedo surgiu uma importante clivagem entre a velha e a nova geração. Todos os timorenses estavam unidos em relação à fundação do novo estado; divergiam, no entanto, quanto à questão da língua e da cultura [...] Neste momento existem duas perspectivas antagónicas sobre a identidade cultural de Timor-Leste, e entre estas existe todo um leque de correntes e pontos de vista. Por um lado, os elementos da velha geração querem que o português seja a única língua oficial, e não prevêem qualquer tipo de estatuto oficial para o tétum ou para os outros vernáculos. No extremo oposto, estão os jovens que querem que apenas e só o tétum seja a língua oficial, manifestando-se deveras apreensivos em relação ao português. (HULL, 2001:33)
\end{abstract}

Geoffrey Hull e Regina Helena Brito descrevem a complexidade linguística e étnica em Timor. Esses autores oferecem uma futura perspectiva positiva ao ensino do português, pelo fato de, ao final, os timorenses terem adotado a língua portuguesa como idioma oficial, apresentando os efeitos dessa escolha. Segundo Hull, a não inclusão da língua portuguesa como língua oficial implicaria apagar da memória do povo algo intrínseco à história viva daquele país (HULL, 2001:39).

Hull inicia seu texto contando a história da Indonésia, que, ao se tornar independente da Holanda, optou pelo malaio, e não pelo javanês, aboliu o uso do holandês e elegeu como segunda língua o inglês. Assim, o mesmo ocorrera na parte Ocidental de Timor, já ocupada pelos holandeses e, quando da invasão indonésia no Timor-Leste, o mesmo mecanismo foi utilizado, ou seja, o português foi abolido das escolas, para que não houvesse mais a presença e a língua que levasse à memória da colonização portuguesa. Em seu texto, portanto, Hull relata a estratégia utilizada pelos indonésios na neo-colonização, que foi a de fechar as escolas de língua portuguesa em Timor e, ao mesmo tempo, forçar o ensino da bahasa indonésia, apagando traços do antigo colonizador e também da própria cultura timorense local. Tal modelo, segundo Hull, contrapõe-se ao modelo do colonialismo clássico português, que também fez imposição do uso de seu idioma, catequizando os povos locais, mas que, 
em contrapartida, permitia a preservação de algumas tradições e, de certa forma, do sistema organizacional local.

Da mesma forma, a professora Regina Helena Brito, pioneira na implantação do ensino do português naquele país no período pós-colonial, descreve, em seus estudos, os novos desafios ali colocados na prática do aprendizado da língua portuguesa. A autora discorre sobre as dimensões e as fronteiras da lusofonia, definindo tal conceito e, ao mesmo tempo, relembrando as etapas e as maneiras de ocupação, por parte de Portugal, em cada território que dominava. Assim, ela fundamenta a importância da língua portuguesa no mundo, contextualizando a relevância de tal idioma para o povo timorense, como se deu sua implantação e pelas mãos de quem foram transmitidos os primeiros ensinamentos:

Em Timor-Leste, como em cada um dos outros espaços de sua oficialidade - Angola, Brasil, Cabo Verde, Guiné-Bissau, Moçambique e São Tomé e Príncipe - a língua portuguesa conhece e constrói a sua própria história. E, por isso, está muito longe de ser tratado como um idioma uniforme. É com essa perspectiva que se deve encarar 0 "desafio" da língua portuguesa em Timor-Leste: está-se diante de mais uma variedade do português. E, como tal, devemos atentar para a necessidade urgente de uma descrição do português ali praticado (observando-se as influências que recebe do contato com as demais línguas ali faladas) e incentivar a descrição e sistematização da língua tétum, respeitando, sobretudo, as experiências particulares, os valores diferentes, a especificidade cultural e a visão de mundo que a sociedade timorense vem imprimindo na construção da norma do português timorense, ao mesmo tempo em que reconstrói a sua identidade como nação. (BRITO, 2010:18)

Com a instauração dos programas de ensino de língua portuguesa em Timor, após a independência do país, há largo espaço para questionar os mandos e desmandos do colonialismo português na ilha. Após dez anos de independência, os programas que preservam o ensino da língua portuguesa continuam vigorando, segundo acordos que envolvem os governos de Timor, Brasil e Portugal.

Sobre o ensino da língua portuguesa em Timor, cabe lembrar a iniciativa de Regina Helena Brito e Benjamin Abdala Junior, que assinaram o programa para a sensibilização para a comunicação em língua portuguesa à 
população de Timor-Leste. Como fruto dessa parceria, surgiu o livro Sensibilizando para a comunicação em língua portuguesa - uma experiência em Timor-Leste, de autoria das professoras Regina Helena Brito, Rosemeire Faccina e Veria Lúcia Busquets, que, por meio de músicas populares brasileiras, procuraram incentivar, especialmente a parcela jovem da população, a se expressar em língua portuguesa a partir do gosto pela música brasileira, nesse novo método para o ensino do idioma em 2006. Nesse contexto, salienta Brito a realidade linguística do país e o que seria esperado, em termos de vivência com outros povos após a independência. Ressalta ainda a importância do idioma português para o resgate da identidade cultural e nacional em Timor:

Timor-Leste, ao se tornar, a partir de 2002, uma das mais jovens democracias do mundo, assim como o país mais novo do terceiro milênio, passa a fazer parte do mundo globalizado, em que a mobilidade geográfica, as trocas profissionais, 0 turismo, 0 entretenimento, a comunicação de massa e os caprichos da vida moderna podem dar a uma pessoa identidades culturais múltiplas, já que as fronteiras da identidade cultural são ampliadas e modificadas diariamente. Juntamente com o desafio de resgatar o português como língua oficial, que os unirá numa nação, os timorenses enfrentarão diálogos com pessoas com diferentes backgrounds linguísticos e culturais, o que os obrigará, nessa realidade, a compreender as diferenças em comportamento e de pontos de vista, também, daqueles que compartilham a mesma língua e cultura nacionais. (BRITO, 2006:151)

Ainda hoje, a CAPES - Coordenação de Pessoal de Aperfeiçoamento de Nível Superior, órgão de fomento educacional, encaminha brasileiros a Timor-Leste, num programa de cooperação para a continuidade do ensino da língua na região.

Vale lembrar que os vários projetos de cooperação em Timor-Leste foram iniciados em 1999. Com o final da ocupação indonésia, o Governo Brasileiro por meio da Agência Brasileira de Cooperação (ABC) iniciou um projeto de apoio à reconstrução do país.

Os primeiros projetos em Timor-Leste foram os de implementação do Centro de Promoção Social, Formação Profissional e Desenvolvimento Empresarial de Becora, em parceria com o Serviço Nacional de Aprendizagem 
Industrial. Da mesma forma, os programas de cooperação entre Portugal e Timor-Leste tiveram início em 1999, e estão em vigor há mais de dez anos. Os projetos iniciados pelos portugueses visavam, em primeiro lugar, a assistência jurídica, eleitoral e social.

Portugal e Brasil, até o presente momento, mantêm programas e projetos para a difusão da língua portuguesa em Timor-Leste, desde o ensino básico até a formação e capacitação de docentes, multiplicadores para a manutenção do aprendizado do português. A Universidade Nacional de Timor Lorosa'e dispõe de cursos de atualização para docentes na área de língua portuguesa.

De modo geral, por parte dos timorenses, o aprendizado do português é acolhido de maneira ampla, pois há interesse por parte da população em aprender a língua. Atualmente, nas escolas governamentais em Timor, o ensino da língua portuguesa é iniciado a partir do quinto ano escolar. Nem todos os alunos prosseguem com os estudos desse idioma, contudo, um número razoável consegue desenvolver o aprendizado, a ponto de ingressar em universidades em Portugal e no Brasil. 


\subsection{A notícia escrita em Timor: imprensa em língua portuguesa}

Abordar a questão da imprensa em língua portuguesa em Timor-Leste se faz mister neste trabalho, ainda que de maneira breve, pois a proposta é avaliar a produção literária de língua portuguesa do país. Assim, é necessário saber como e em quais circunstâncias surgiu a imprensa escrita em Timor, a par do que acontecia nas outras colônias portuguesas nesse mesmo âmbito, bem como quem escrevia nesses periódicos, o que era publicado de fato e a quais interesses serviam.

Além de veículo de comunicação, o interesse da imprensa para uma população e para uma nação se constitui na medida que funciona como a memória cotidiana de um povo. Ademais, destacamos que, invariavelmente, como ocorrera em muitos países, a imprensa foi um meio utilizado para a publicação primeira de novelas, crônicas e demais gêneros literários. Romances eram publicados em folhetins, nas seções dos periódicos, capítulo a capítulo, e somente depois eram transformados em livros, da forma como os conhecemos atualmente. No Brasil, por exemplo, temos as crônicas de Machado de Assis, que eram publicadas no periódico A Gazeta de Notícias, no Rio de Janeiro.

A despeito do que ocorria nas colônias portuguesas na África e também no Brasil, onde a notícia escrita só passou a ser veiculada muito depois da chegada dos portugueses, com a conquista dos territórios no Extremo Oriente - Macau, Goa e Timor-Leste - a situação diferia nesse particular.

Em Angola, por exemplo, o primeiro periódico, Boletim Oficial, foi fundado em 1845, pelo governador Pedro Alexandrino da Cunha e, ainda assim, este jornal apenas desempenhava as funções de um jornal rudimentar, embora tenha sido o ponto de partida para o desenvolvimento do jornalismo na capital angolana (ERVEDOSA, 1985:24).

No Brasil, a criação do primeiro jornal, $A$ Gazeta do Rio de Janeiro, deuse em 1808, com a chegada da família real portuguesa, passando a veicular notícias do Brasil para Portugal. 
No Oriente, os propósitos da colonização eram diversificados; por um lado, em algumas colônias, havia o intenso tráfico de escravos, de outro lado, o que movia o interesse dos portugueses era a busca por especiarias. Portanto, a dinâmica, no que tange à transmissão de notícias, surgiu de maneira diversificada, atendendo aos propósitos, sobretudo, da elite que se criava em cada local.

Em Oriente, engenho e arte (2004), Helder Garmes remonta à situação da imprensa escrita nas colônias portuguesas, sobretudo nas colônias situadas no Oriente. Segundo Garmes, a imprensa iniciou-se tardiamente no Brasil e na África, com início efetivo em meados de 1800. No Oriente - Goa e Macau -, as primeiras obras impressas pelos portugueses datam do século XVI. Isso se deu sobretudo pelo fato de Goa ter sido a sede do governo português no Oriente (GARMES, 2004:16).

\begin{abstract}
Lembremos que antes do estabelecimento das imprensas nas colônias no século XIX, as comunidades locais, constituídas de europeus e habitantes locais de diversas origens, encontravam-se quase integralmente isoladas da metrópole no que concerne à escrita literária. Após um primeiro momento de forte atividade missionária no século XVI e em parte do século XVII, as comunidades coloniais foram culturalmente abandonadas pela metrópole portuguesa. Aos que ali se encontravam estabelecidos, restara uma única atividade e função: enriquecer. Nos séculos XVII e XVIII os investimentos educacionais foram ou nulos, ou precários e pouco sistemáticos, sem jamais recuperar o desempenho das missões quinhentistas, que buscaram a conversão de almas utilizando-se da literatura e das artes como meio de dogmatização. (GARMES, 2007:34)
\end{abstract}

No decorrer do século XIX, a imprensa se expandiu nas colônias, mas os meios literários ainda eram incipientes, sendo muito pragmático e instrumental o lugar que o texto escrito ocupava em tais localidades:

No século XIX, após a instalação de máquinas impressoras nas colônias, iniciou-se, pois, um novo momento de valorização da escrita, da literatura e das artes, que se viu diante da tarefa de reinstaurar 0 valor de tais atividades nas colônias. Sem a grandeza que lhes era atribuída na Europa, as artes em geral e a literatura em particular ganharam inicialmente uma dimensão utilitária, laudatória, moralizadora e política, fazendo que tivessem algum sentido e lugar 
aos olhos da comunidade colonial, há muito apartada de tais hábitos. (GARMES, 2007:34)

Timor não teve imprensa no século XIX, ficando subordinado a Macau. Embora houvesse uma elite emergente, para que a imprensa tivesse início na região, foi necessária a intervenção da igreja católica para que isso ocorresse. Assim, somente em 1948, a revista Seara surgiu em Timor para, em princípio, veicular as notícias no meio eclesiástico. Foi por meio do rev. p. Jorge Barros Duarte, sacerdote, que idealizou, junto à Diocese de Díli, o projeto de criação da revista. A publicação serviria para romper o isolamento entre os membros da comunidade eclesiástica na ilha, trocando informações por meio dela. O periódico recebia contribuições de missonários, principalmente por parte do padre Ezequiel Enes Paschoal, que contribuiu com muitos artigos e resenhas de cunho religioso. Algumas publicações versavam sobre as tradições do Timor.

Paulo Pires, em seu artigo "A imprensa em Timor antes do 25 de Abril", aborda o tema, explicitando, inicialmente, as condições para a existência da imprensa em Timor:

Ao referirmo-nos à imprensa em Timor, entendemos a imprensa em Língua Portuguesa. Isto implica que:

- em primeiro lugar, os editores dominem a língua de Camões;

- em segundo lugar, o público leitor/consumidor saiba ler e se interesse pela leitura para a interpretar conveniente e objectivamente;

- em terceiro lugar, para escrever e publicar são necessárias condições da sua efectiva exequibilidade. (PIRES, 2000:136)

Era necessário um bom domínio do idioma português para a publicação no periódico, assim como o público leitor também deveria possuir conhecimento necessário do português para a leitura e, por fim, seria necessário o provimento material devido para a execução ou a realização do periódico. 
Os missonários em Timor, a despeito de seu atraso, considerando que Goa e Macau começaram a atividade na imprensa escrita muito antes, tinham o desejo de trocar notícias e publicar seus textos por meio de um veículo informativo. À época, esse informativo era direcionado aos eclesiásticos, portugueses residentes na ilha, funcionários timorenses que trabalhavam para a administração portuguesa, ou seja, a elite timorense que teve a oportunidade de aprender o idioma.

Mais tarde, a Revista Seara serviu como veículo para as questões políticas, principalmente à época anterior aos partidos políticos serem criados em Timor e à consequente desocupação portuguesa. Embora a revista tivesse viés religioso, serviu também de canal para artigos e comunicações dos partidos formados em Timor-Leste e, por isso, sofreu repressões por parte do governo:

\begin{abstract}
A geração de políticos timorenses que surgiu nos inícios dos anos 70 , mais proactiva politicamente, poderá ter retirado lições e inspiração dos acontecimentos e das consequências. Começaram a publicar os primeiros artigos de cariz político no suplemento da Seara no Boletim Eclesiástico da Diocese de Dili, tendo a publicação sido encerrada pela PIDE a 10 de Fevereiro de 1973. Nela escreveram figuras de Timor como Ramos-Horta, Nicolau Lobato, Mari Alkatiri, Francisco Xavier do Amaral, Domingos de Oliveira, Francisco Borja da Costa e Manuel Carrascalão. (Adão apud GUNN, 1999)
\end{abstract}

O governo administrativo português em Timor certamente cerceou manifestações que contivessem críticas contrárias à administração colonial exercida. Contudo, não fica claro até que ponto a classe eclesiástica era conivente com as publicações políticas, ainda que estas tenham sido permitidas pelos agentes que publicavam o periódico.

Paulo Pires afirma ainda a existência de outros periódicos em Timor, sem precisar a ordem cronológica da criação desses veículos comunicativos. Dessa forma, ele menciona A Província de Timor, que era um periódico de cunho militar, criado pela classe militar, uma instituição muito presente em Timor e que, segundo o autor, pelo seu caráter íntegro, "não quis deixar-se prender nas malhas do poder político" (PIRES, 2001:143). 
A Província de Timor noticiava assuntos da região ligados ao âmbito militar, que estariam fora, portanto, dos interesses públicos.

Também menciona $A$ Voz de Timor, que em princípio era um periódico ligado ao governo, publicava notícias referentes às decisões tomadas pelo governo e também acontecimentos relacionados aos membros da administração portuguesa em Timor e outras colônias portuguesas.

Aos poucos, porém, A Voz de Timor foi recebendo notícias diferenciadas para publicação. Após o 25 de Abril de 1974, as tiragens do periódico, que passou a ter mais páginas, aumentaram. Nele, já eram publicadas, então, notícias referentes à política e aos partidos políticos, pois, em Timor, já havia uma juventude letrada, ativa e militante (PIRES, 2001:143).

É certo que, após a invasão do exército indonésio, a situação mudou: o ensino do português foi proibido, escolas foram fechadas, assim como veículos de comunicação em língua portuguesa foram proibidos.

Dos periódicos aqui citados, resta, contudo, a beleza de seu conteúdo. Fora o conteúdo de caráter eclesiástico, havia também lendas e estórias de Timor, que retratavam sua tradição e, por fim, declarações de viés político, já à época da formação da resistência. 


\section{CAPÍTULO 2}

\section{Da poesia}

Porque é que a cabeça do timor há-de-curvar eternamente? Porque é que o timor há-de ser escravo para sempre?

Acorda que a madrugada já desponta

Acorda que o novo sol já desponta

("Monte Ramelau", Francisco Borja da Costa)

\subsection{Considerações sobre a poesia do Timor}

A poesia timorense, como a conhecemos na atualidade, pode ser dividida em vários momentos, pois foi escrita em períodos distintos: período colonial, período pós-colonial e também da Resistência Timorense, período da reconstrução. Tratando-se de um trabalho de compilação de textos, é necessário considerar, em primeiro lugar, o material que chegou às nossas mãos até os dias de hoje e, dentre ele os autores que contribuíram e se destacaram, de alguma forma, dentro do contexto histórico em Timor-Leste.

No que tange aos autores nascidos em Portugal e que escreveram sobre Timor, a cultura timorense tocou-os tão profundamente, que, em suas obras, alguns poemas que tratam dessa realidade multifacetada merecem destaque em seus escritos.

Damos início a este capítulo citando autores como Alberto Osório de Castro e Ruy Cinatti, que, pelo período de suas vidas que dedicaram ao Timor, colonial e pós-guerra, respectivamente, propagaram ao Ocidente o que existe 
no país em termos de beleza física e também em termos políticos, estimulando a curiosidade dos leitores.

O primeiro autor, Osório de Castro, poeta já consagrado em Portugal, ao chegar a Timor e, já tendo produzido escritos pelos países que percorreu no Oriente, escreveu parte de sua obra em terras timorenses, quando lá esteve, entre 1908 e 1911. Foi uma época de revoltas e sublevações, tendo em vista a administração colonial imposta pelos portugueses, que exigiam tributos pesados dos chefes dos sucos regionais e, consequentemente, da população.

Já no período posterior à invasão japonesa, que se deu em 1942 e teve seu término em 1945, Ruy Cinatti, agrônomo e administrador, chega a Timor. Ao visitar o território e efetuar suas pesquisas, em meio aos destroços deixados pela ocupação japonesa, Cinatti escreveu diversos poemas ${ }^{15}$, dentre os quais escolhemos alguns para transcrever e analisar neste trabalho.

Outra fase distinta em Timor é a da invasão do exército indonésio, à época da descolonização. Com a guerra civil anterior, que gerou tal invasão, e posterior organização da milícia, formada pela resistência à ocupação, surgiram os soldados escritores, poetas engajados. A coletânea Enterrem meu coração no Ramelau, editada pela União dos Escritores Angolanos, em 1982, com poemas de oito autores (Fernando Sylvan, Borja da Costa, Eugénio Salvador Pires, José Alexandre Gusmão, Oky do Amaral, M. Leto, Mali Manek e Jorge Lauten), apresenta-nos uma série de escritos dos poetas na época da descolonização, textos repletos de emoção e revolta, denúncia viva dos acontecimentos que se seguiram à saída de Portugal do território timorense.

Após a consolidação da invasão indonésia, encontramos, entre os autores contemporâneos, João Aparício e Abé Barreto.

A poesia aqui citada, escrita em língua portuguesa, tem características peculiares, havendo também um propósito para que tal poesia tenha sido escrita no referido idioma, e não em tétum, por exemplo. Aos que questionam a importância da língua portuguesa em Timor, em detrimento da língua inglesa

${ }^{15}$ Por se tratar de uma coletânea geral, na qual estão inseridas obras de outros autores, destacamos apenas alguns poemas de Ruy Cinatti que tratam sobre o Timor para transcrição e análise. Tais poemas foram publicados nos livros Um cancioneiro para Timor (1980) e Paisagens timorenses com vultos (1996). 
ou da bahasa indonésia, estudos propõem as respostas e as motivações pelas quais a escolha foi feita pela própria população em Timor. 


\subsection{Alberto Osório de Castro: juiz e poeta}

Alberto Osório de Castro, poeta e prosador, nasceu em Coimbra, em 1868, e morreu em Lisboa, em 1946. Proveniente de família ilustre, da região da Beira Alta, durante sua infância, estudou em Mangualde e Viseu. Estudou Direito na Universidade de Coimbra e, sendo amigo de Camilo Pessanha, fundou a revista Boémia Nova, em 1889, também com os amigos António Nobre e Eugénio de Castro, na qual, sob o pseudônimo de Dr. Fausto, publicou reflexões literárias e também alguns poemas. Mais tarde, tal publicação entraria em disputa com a revista Os Insubmissos, lançada pelos autores Francisco Bastos, Eugénio de Castro e João Menezes ${ }^{16}$. Os textos de Osório de Castro, de relevo e destaque na revista Boémia Nova, em disputa acirrada com a revista de seus oponentes, conferem ao autor o título de "messias literário" do fim do século ${ }^{17}$. Mais tarde, ao ingressar na magistratura, Osório de Castro viaja por Goa, na Índia, e Moçâmedes, em Angola, exercendo o ofício de juiz. Solicita, então, transferência para Timor, onde permanece de 1908 a 1911.

De fato, ao se deslocar para o Oriente, à época de um momento de reestruturação da administração portuguesa em Timor, Osório de Castro encontra nas terras timorenses o seguinte quadro: um ambiente de revoltas e insatisfação e a preparação para aquela que seria provavelmente a maior insurreição contra a Coroa Portuguesa por parte dos timorenses: a Revolta de Manufahi.

Entre 1844 e 1863, ocorrem mudanças quanto à adminstração territorial em Timor. O território, que era politicamente administrado por Goa, juntamente com Macau, passa a ser administrado diretamente por Portugal a partir de 1863, recebendo o status de província ultramarina (ADÃO, 2009:17). Assim, a instabilidade referente à administração política do território e, consequentemente, a finalização entre o comércio direto instaurando entre

\footnotetext{
${ }^{16} \mathrm{~A}$ gênese da disputa entre as duas revistas é a questão dos versos alexandrinos, no que se refere à colocação da cesura. Eugênio de Castro, tendo introduzido o Simbolismo em Portugal, reivindica para si o pioneirismo de introduzir em Portugal uma métrica menos ortodoxa, ainda que valorizasse a métrica clássica.

${ }^{17}$ Ver em Castro, Alberto Osório, Obra Poética. Vol.I (2004:9).
} 
Goa-Macau-Díli, trouxeram insatisfação e dissabor para os timorenses, o que gerou revoltas durante o século XIX e o início do século XX, somando-se a isso a constante disputa do território entre portugueses e holandeses ${ }^{18}$.

Em 1904, a Convenção Luso-Holandesa demarca os territórios e os direitos de Holanda e Portugal sobre o arquipélago de Timor e Solor, o que é ratificado em 1908 (FIGUEIREDO, 2000:521). A disputa entre Portugal, detentor das terras de Timor Oriental, e Holanda, que detinha o domínio sobre a parte ocidental de Timor, levou anos entre acordos, tratados e invasões, só atingindo o seu término em 1949, quando, após a proclamação da República dos Estados Unidos da Indonésia, a parte ocidental de Timor foi anexada ao novo país.

Assim, a administração por parte de Portugal, exercida de forma conjunta em Macau e em Timor, em 1896, separa as duas colônias do Extremo Oriente. Internamente, entre Macau e Timor os contatos eram limitados em sua base comercial. Para Timor, embora houvesse dependência e a rede comercial pudesse obter mais lucros quando havia associação direta com Macau, pois o comércio era interligado, não havia meio de comunicação para repassar informações relativas à área comercial. A essa altura, Portugal preferia suspender o comércio entre as colônias e separá-las administrativamente, para que pudesse cobrar mais impostos. Em Timor, para satisfazer os timorenses nativos, Portugal propiciava a distribuição de títulos e cargos administrativos, concedendo privilégio a quem recebesse as referidas premiações.

De fato, após a partilha do território e o consequente domínio de Timor Oriental por parte dos portugueses, algumas mudanças administrativas provocaram desgostos e motivaram revoltas internas. Após a Conferência de Berlim (1884-1885), em que foram divididas as colônias africanas, Portugal buscou uma efetiva presença no Oriente. Contudo, em Timor, especificamente, onde a economia fundada na agricultura com trabalhos forçados e também onde os portugueses implantaram novas políticas para minar o sistema de alianças de parentesco existentes na região, as revoltas começaram a eclodir e

\footnotetext{
${ }^{18}$ Em 1859, por tratado assinado em Lisboa, o território timorense foi dividido em dez distritos, a saber: Díli, Manatuto, Viqueque, Lautém, Vemasse, Alas, Buursuco, Cailaco, Maubara e Batugadé. O distrito de Oecussi foi anexado 1863, funcionando sob um sistema de administração indireta (ADÃO, 2009:18).
} 
se intensificaram. A união de reinos para lutar contra os portugueses, buscando uma libertação do domínio português, ganhou força. A guerra durou anos e muitos timorenses morreram tentando se libertar do jugo colonialista, como descreve Sakamoto:

Da mesma forma que em suas colônias africanas, Portugal determinouse a expandir efetivamente seu domínio sobre o território timorense. Uma das primeiras mudanças foi forçar o camponês a aumentar a área plantada para além das necessidades de subsistência e gerar excedentes à comercialização, além de pressionar pelo manejo de produtos com alto valor de mercado, como o cacau, o café e a borracha (seringais). Trabalho forçado foi usado no desenvolvimento de infraestrutura e nas plantações. Para que tudo isso fosse possível, Taylor explica que as novas políticas portuguesas implantadas visavam a minar o sistema de alianças por parentesco. Reinos se uniram contra essas medidas e rebeliões aconteceram, como a liderada pelo liurai (rei) de Same, Dom Boaventura, que durou de 1894 a agosto de 1912 quando três mil timorenses morreram nas mãos das tropas portuguesas. (SAKAMOTO, 2002:19)

É nesse contexto que ocorre a chegada de Osório de Castro ao Timor, ele, que, como observado, já vivera em Goa e Moçâmedes, onde já havia escrito poemas. No conjunto de sua obra, os poemas escritos em Timor, principalmente em Lahane, apresentam um lirismo diferenciado.

A obra de Osório de Castro não é muito extensa. Publicou os livros de poemas Exiladas (1895), A cinza dos mirtos (Goa, 1906) e Flores de coral: poemetos e impressões da Oceania Portuguesa (Díli, 1908), dedicado a Fialho de Almeida. Em 1923, publica $O$ sinal da sombra e o livro $A$ ilha verde $e$ vermelha de Timor, memorialista.

O conjunto de sua obra é geralmente qualificado como decadentistasimbolista. Tal caracterização pode ser lida em relação ao contexto português, pois a primeira década do século XX em Portugal é marcada pela crise da Monarquia Constitucional, conjuntamente à forte crise econômica, o que daria motivos reais ao sentimento decadentista. A decadência provinha da própria sociedade, e o tom lúgubre dos poemas era um dos traços principais das obras dos autores da época. Da mesma forma, a preocupação com a estética e a 
produção referente ao esquema métrico e também às rimas estão presentes na poesia de Osório de Castro, conforme veremos a seguir.

O livro Flores de coral é composto de 34 poemas e dois poemas dramáticos, com o subtítulo "Poemetos e impressões da Oceania Portuguesa", tendo sido publicado em Díli em 1910. Alguns poemas são escritos durante a viagem, antes mesmo da chegada a Timor, conforme inscrição textual, indicando o local onde o texto fora escrito. Assim, dos vários poemas, lemos as inscrições Goa, Canal de Suez, Costa de Timor, Moçâmedes, etc. Da obra escrita em Timor-Leste ou durante a viagem a Timor, alguns poemas falam sobre a paisagem da região, outros sobre o modo de vida dos timorenses e outros sobre a própria Corte Portuguesa ou europeia, e os membros que faziam parte dessa corte. Há, sem dúvida, em certa altura da obra, uma intenção de legar ao esquecimento a localização de origem do autor, situada numa terra erma e distante dos luxos e comodidades da metrópole portuguesa.

Elencamos, portanto, poemas que falam da paisagem ou dos costumes da região, por estarem relacionados ao presente trabalho ${ }^{19}$ :

\section{Flores de Coral}

Dispersos pelos mares,

Alguns dias de luz me alvorejaram.

Ondas d'oiro no nácar ${ }^{20}$ dos luares

O meu sonho embalaram,

E em flores de coral, sob os palmares,

Rolaram-no, e passaram.

Em seu poema "Flores de Coral", que dá nome ao livro, o autor fala de seus sonhos, ao viajar para o Extremo Oriente, ressaltando as belas paisagens, os mares, as flores e os luares da região. Como se há de ver, também em outros poemas, a preocupação precípua de Osório de Castro é retratar a beleza de Timor. Inicia falando sobre a viagem: "alguns dias de luz" "dispersos pelos mares". As metáforas no verso "ondas d'oiro no nácar dos

\footnotetext{
${ }^{19}$ No presente trabalho, apenas alguns poemas dos autores serão transcritos, a começar por Alberto Osório de Castro.

${ }^{20}$ Substância branca, rica em calcário, produzida por alguns moluscos, e que reveste a parede das ostras.
} 
luares" denotam uma linguagem cuidadosamente trabalhada para surtir o efeito desejado. Finalizando, cita as flores de coral, que foram, conjuntamente, embaladas com o sonho do poeta.

\section{Às casuarinas do cemitério de Díli}

Sonho escuro dos mortos embalai, Prece das casuarinas ${ }^{21}$ !

Vozes vagas dos mortos, ciciai

Nas folhagens franzinas!

Já no céu, resplandece esmorecendo

A púrpura do dia.

Passa a aragem do pântano gemendo

Na romagem sombria.

Que murmuram as bocas das raízes

Aos mortos a sonhar?

Que lhes dizes, ramagem? Que lhes dizes,

A reza e a embalar?

(Lahane, Timor, Abril de 1908)

Em “Às casuarinas do cemitério de Díli”, o autor apresenta a dança das flores "casuarinas" no cemitério de Díli, a conversar com os mortos: "Que murmuram as bocas das raízes aos mortos a sonhar?". Sem dúvida, o título do poema evoca o tom lúgubre próprio dos autores simbolistas e, por fim, assemelha o som das casuarinas embaladas pelo vento às rezas e preces aos mortos que estão no cemitério.

\section{Tebedai $^{22}$}

Bailemos, bailemos à luz do luar, Que a vida não pára, lá vai passar.

Na sombras do verde gondão ${ }^{23}$ de mil braços Já voam as moscas-de-fogo aos abraços.

${ }^{21}$ Casuarina, árvore cuja designação científica é a Casuarina junghuniana em Tetum-Aikakeu.

${ }^{22}$ Tebedai, dança efetuada pelas mulheres. Geralmente, nas festas, as mulheres dançam o tebedai ao som de instrumentos, tais como babadok e dadir. As notas deste poema são de D. Ximenes Belo sobre a obra de Osório de Castro. 
Reparem! Lá dançam no luar as estrelas,

Sárão ${ }^{24}$ todo d'oiro, doiradas chinelas.

Era uma vez um malai ${ }^{25}$ português

Que em todo o batuque dançava por três.

Tanto bailou com as moças alegres

Tanto bailou que lhe deram as febres.

Tanto bailou e tornou a bailar,

Que até para a cova lá foi a dançar.

Bailemos, ao som dos sagueiros.

Não têm toada mais fina os ribeiros.

Suspiros das folhas do verde gondão,

Abraços e beijos, são do coração.

Bailemos, bailemos, à luz do luar,

Que a vida não pára, lá vai passar.

(Lahane, Timor, Junho de 1908)

A dança do malai português o leva a uma morte lúdica, embevecida de prazer e sensualidade. Osório de Castro agencia aqui a imagem da sensualidade associada ao Oriente, fazendo com que o tebedai, isto é, o estrangeiro, o português, o "homem civilizado", seja cooptado por tal sensualidade, deixando-se levar na vida como na dança. Ainda que poema trabalhe com um estereótipo ligado ao Oriente, procura, contudo, apresentar uma imagem positiva dessa realidade.

A obra de Osório de Castro primeiro divulgou o Oriente e também TimorLeste, por meio de seus escritos, durante a viagem que fizera, ao regressar a Portugal. Embora sua obra não reflita os acontecimentos inerentes à época, há, contudo, um pendor para a valorização das descrições das paisagens e do modo de vida local, bem como de ritos e danças típicas na região.

\footnotetext{
${ }^{23}$ Gondão, ou gondoeiro: árvore frondosa. Algumas têm raízes aéreas e são cientificamente chamadas Ficus benjamina, em Tetum-Hali. É considerada sagrada para alguns timorenses.

${ }^{24}$ Sarão, ou sarong, em idioma malaio, em tétum chamado lipa, é um pano usado pelas mulheres.

${ }^{25}$ Malai significa pessoa estrangeira, ou pessoa civilizada.
} 
Mathias Langendorff, em Timor na poesia de Ruy Cinatti e Alberto Osório de Castro, ao comparar a obra dos dois autores, entende que Osório de Castro apresenta um discurso colonialista, conforme definido por Edward Said, ao passo que Cinatti se identifica profundamente com a geografia física e humana de Timor, "em termos de identidade individual, quanto à pertença a esse espaço" (LANGENDORFF, 1999:321).

Embora trate inicialmente da obra em prosa escrita por Osório de Castro, as características aqui apresentadas compreendem também a estética que se verifica nos poemas do autor:

(...) no texto de Osório de Castro, o mundo aparece-nos como um espaço povoado de objetos, mencionados e rotulados de forma tendencialmente exaustiva, mas entre os quais não se percebem os nexos fundamentais, nem os acontecimentos ou vivências de percurso que Ihes possam estar associados. (LANGENDORFF, 1999:324)

Apresenta, de forma elaborada, os recursos que o autor emprega em seu texto, finalizando por caracterizar sua poesia:

\begin{abstract}
A escrita, de um ponto de vista mais estilístico, caracteriza-se pela verbalização predileta de experiências sensoriais, sobretudo odores e experiências visuais; o vocabulário usado para dar conta dessa impressão é geralmente rebuscado e, por vezes, recheado de termos contraditórios. Assim, nem sempre resulta claro qual o estatuto da experiência verbalizada. Nalguns casos ela é pretexto para utilização de um vocabulário rebuscado, recurso revelador de uma poética que pretende que a escrita adquira um cunho plástico; esta poética relega a adequação referencial para segundo plano e, então, podemos falar de um procedimento parnasiano. (LANGENDORFF, 1999:324)
\end{abstract}

Por fim, contrariamente ao que acontece com os demais poetas engajados e também com Ruy Cinatti, como veremos a seguir, percebe-se que Alberto Osório de Castro, embora represente em seus poemas as paisagens e o modo de vida timorense, coloca-se alheio aos fatos políticos e às necessidades do povo de Timor. Sua escrita, nesse particular, não representa uma escrita sobre a efetiva realidade timorense, embora seja um autor representativo, à época, principalmente por ser o primeiro a descrever, em 
suas poesias, os ritos e as tradições timorenses e, de certa maneira, chega a inspirar a escrita de Ruy Cinatti, que mais profundamente conheceu a terra dos timores. Sem dúvida, o olhar de Alberto Osório de Castro representa a visão primeira que se tem de Timor, corroborando a visão que apresentou das demais áreas dominadas por Portugal por onde passou. 


\subsection{Ruy Cinatti, um caso à parte}

Ao longo dos dias, ao longo dos anos muitas vezes falei de Timor com o Rui. Contou-me como celebrara o pacto de sangue com o chefe de uma família timorense e como por isso, segundo a lei ancestral de Timor, se tornara ele próprio um timorense. De facto para ele Timor era uma verdadeira pátria.

Sophia de Mello Breyner Andresen

Considerado por muitos escritores como autêntico timorense, pelo amor dedicado à Ilha de Timor-Leste, o engenheiro português Ruy Cinatti tem seu lugar de destaque na poesia e literatura desse país. Não fora em vão que, nos umbrais da casa de Sophia de Mello Breyner, Ruy Cinatti encantou a todos, inclusive a ela, com sua contação de estórias sobre Timor e os timorenses ${ }^{26}$. Ainda não eram os horrores da guerra, que mais tarde comoveriam as nações do mundo, mas estórias simples e costumes de um povo longínquo que, de certa forma, fora sempre esquecido pelos portugueses.

Nascido em Londres, em 1915, Ruy Cinatti Vaz Monteiro foi a Timor pela primeira vez em 1946, período do término da ocupação japonesa, iniciada em 1942, durante a Segunda Guerra Mundial. Seu avô materno, diplomata português, foi quem acompanhou de perto sua educação, pois fora por ele acolhido ao perder a mãe, quando tinha 2 anos de idade, e também mais tarde, ao entrar em embates com o pai, por conta de divergências relativas a seu curso superior, mudando-se definitivamente para a casa do avô, a fim de poder cursar Agronomia ${ }^{27}$.

Timor, à época da Segunda Grande Guerra, foi invadido e devastado pelos japoneses, que tinham grande interesse na região. Pelo simples fato de estar próximo ao território australiano, Timor-Leste serviria como uma base

\footnotetext{
${ }^{26}$ No livro de João Aparício À janela de Timor (1999), logo no prefácio de Sophia de Mello Breyner Andresen há referências à chegada de Ruy Cinatti, de Timor-Leste, mostrando objetos que trouxera consigo das terras timorenses, dançando a dança típica de Timor e recontando as lendas daquele país, na varanda da casa da escritora.

${ }^{27}$ De fato, Ruy Cinatti nasceu em Londres, quando seus pais viviam com seu avô materno, que era diplomata. Ao perder a mãe, quando era criança, seu pai o deixou com os avós e foi viver nos Estados Unidos e, ao regressar, contraíra segundas núpcias. Nessa altura, porém, pai e filho já não se entendiam, pois Ruy queria ser agrônomo e seu pai desejava que ingressasse na Marinha.
} 
importante aos japoneses, assim que estes decidissem atacar os Aliados. Entre 1942 e 1945, as tropas japonesas lutaram contra os Aliados em território timorense, fazendo com que mais um conflito tingisse de sangue o TimorLeste. Vários autores ${ }^{28}$, sobretudo portugueses, descrevem a invasão do território timorense, quer por Aliados, quer por japoneses, durante a Segunda Grande Guerra Mundial.

$\mathrm{Na}$ altura, a situação instaurada em Timor era a seguinte: após o Ato Colonial de $1930^{29}$, o poder que, naturalmente, já era de Portugal, foi retirado das colônias que mantinham certa autonomia, referente ao comércio estabelecido entre elas. Assim, o comércio direcionado entre Díli-Goa-Macau, sem a interferência da metrópole, passou a ser realizado apenas via Lisboa.

Tudo passa a ser diretamente conduzido a partir de Lisboa e, para tanto, são delegados poderes às instâncias locais, comandadas pelas elites coloniais, tais como: conselhos, administração, igreja católica, proprietários de plantações portuguesas e exército (TAYLOR, 1991:41).

Com o ato instaurado, são criadas as duas categorias de indivíduos em Timor: indígenas (nativos não assimilados) e não indígenas (incluindo brancos, mestiços e nativos assimilados). Os assimilados, no entanto, que podiam adquirir cidadania portuguesa, precisavam ter certo rendimento, a fim de sustentar sua família, provar seu bom caráter e falar o português. Isso valia apenas para os que não haviam sido designados pela Administração, para qualquer cargo, nem trabalhavam no comércio. Os referidos assimilados eram os que poderiam exercer o direito a voto para eleger a Assembleia Nacional Portuguesa, ou para o conselho legislativo local. Aí estava a gênese da elite política em Timor, que surgiu no período pós-guerra do Pacífico e teria grande importância na luta pela independência (Idem).

${ }^{28}$ BORDA d'Agua, Flávio. Le Timor face à Seconde Guerre Mondiale (1941-1945), 2008; BRETES, Maria da Graça. Timor: Entre invasores (1941-1945).Lisboa: Livros Horizonte, 1989; SANTA, Jose Duarte. Australianos e japoneses na II Guerra Mundial. 1941-1945. Lisboa: Notícias Editorial, 1997.

${ }^{29}$ Salazar assumiu o cargo de ministro das colônias, quando foi instituído o Ato Colonial, Decreto 18.570, com forte caráter nacionalista, que garantia o domínio de Portugal junto às suas colônias, antes denominadas "províncias ultramarinas". A partir de uma crise em Angola, 0 ato instituído teve abrangência no continente africano e nas demais colônias de Portugal, 0 que atingiu Timor. 
Pelo sistema colonial descrito, os poderes da igreja católica já haviam sido pouco a pouco incorporados à sociedade timorense. Seminários criados para a educação dos filhos dos funcionários da administração portuguesa serviam também aos filhos dos timorenses que trabalhavam para a mesma administração e eram dirigidos pelas missões católicas portuguesas.

Tal sistema não realizou, de fato, mudanças radicais na estrutura organizacional da sociedade timorense, que ainda tinha seus líderes nos sucos, os liurais. No entanto, a dominação portuguesa que promoveu o ensino aos filhos dos timorenses que trabalhavam para a administração local contribuiu de maneira relevante para a formação e a consolidação da elite colonial em Timor. Esse sistema de ensino, porém, foi temporariamente suspenso com a invasão e o domínio dos japoneses, durante a Segunda Guerra Mundial.

As causas da invasão japonesa podem ter sua origem na desídia por parte dos portugueses que, ao postergarem suas decisões, deixaram uma lacuna para que outros países dominassem o território durante o período bélico da Grande Guerra. Diante da política salazarista, que, durante os embates da Segunda Guerra Mundial, pretendia manter a neutralidade portuguesa a todo custo, temos, em Timor-Leste, uma das principais vítimas dessa política, servindo seu povo de escudo aos adversários que ali se enfrentavam.

Quando a Segunda Guerra Mundial tornou-se iminente, a ameaça de ocupação de Timor foi se agravando. Durante a guerra, as autoridades portuguesas residentes em Timor depararam-se com a seguinte situação: os japoneses que viviam na região, trabalhando na Sociedade Agrícola Pátria e Trabalho, instavam as autoridades portuguesas a construir uma base aérea, a fim de intensificar o comércio do algodão, produto da associação agrícola. $\mathrm{Na}$ verdade, queriam a base para reforçar o seu poderio na região e marcavam presença, incentivando casamentos entre japoneses e mulheres timorenses. Com a formação dessas famílias, no caso de um ataque dos Aliados, os japoneses seriam protegidos pela população nativa.

Por outro lado, australianos, junto com holandeses, solicitavam autorização dos portugueses para enviar tropas aliadas, a fim de defender 
preventivamente o povo timorense, no caso de um ataque nipônico. Alegavam a posição frágil da Austrália, que lutava junto com os países Aliados na guerra.

Os representantes do governo português em Díli aguardavam a decisão de Salazar, para que houvesse um pronunciamento oficial nesse sentido, visto que as tropas australianas e holandesas já haviam manifestado interesse em "proteger" Timor. Tal proteção consistia em exercer o domínio na região:

\begin{abstract}
Ainda antes das hostilidades, australianos e japoneses, futuros invasores, procuraram assegurar a sua presença na ilha tentando aumentar o número de residentes na mesma. Esta intenção é particularmente clara na "pequena guerra" das carreiras aéreas, efectuadas tanto por japoneses como por australianos, ligando os respectivos territórios a Díli, sem que aparentemente fosse determinante, ou mesmo importante qualquer factor econômico. Este, no entanto, não se encontrava ausente, ainda que não pudesse explicar o esforço de estabelecimento das referidas carreiras. (BRETES, 1989:19)
\end{abstract}

Salazar manteve a neutralidade, até dezembro de 1941, quando os Aliados decidiram não mais esperar e, justificando sua ação como medida de segurança, invadiram Timor-Leste. Ato contínuo, os japoneses invadiram também Timor, dando início a um dos episódios mais violentos da história daquele povo. Esse episódio, relatado à época, ficou esquecido pelos relatos oficiais até meados dos anos 1980, quando foi resgatado pelos historiadores portugueses. Desde então, historiadores de todo o mundo pesquisam e publicam sobre os fatos mencionados. A situação instaurada pela neutralidade portuguesa casou danos e consequências, demonstrando o verdadeiro poderio português na região:

As sucessivas invasões do território de Timor colocaram o governo português numa situação delicada. A persistência da defesa da neutralidade portuguesa coincidira ironicamente com o facto de uma das colónias portuguesas servir precisamente de palco para o conflito entre dois inimigos. Ainda que se verificasse na prática o colapso da administração portuguesa (a ponto de a própria resolução dos conflitos entre a população indígena reservada ciosamente pelas autoridades coloniais portuguesas ser solicitada pelos habitantes da ilha aos ocupantes) ambos persistem em afirmar o respeito por uma soberania portuguesa que simplesmente não existia. (Idem, 1989:36) 
Nesse contexto, chegando em Timor logo após a ocupação japonesa, durante a guerra, foram verificados os estragos causados. Ruy Cinatti, ao se deparar com o Timor pós-guerra, não deixa explícito em seus poemas o que viu, mas em seus escritos faz uma descritação da total devastação, conforme citação no livro de Peter Stiwell:

Não se podem imaginar os estragos causados pela fúria de destruição dos japoneses. São os edifícios e as florestas. Foram as manadas de cavalos e os rebanhos de búfalos. Até os veados. E o estado miserável da população (...) confirma o martírio e a fome a que a ilha esteve sujeita desde 1942. (STIWELL, 2000:153)

A par do relato de Ruy Cinatti sobre a invasão japonesa em Timor, também se pronuncia Taylor, ao relatar as agruras sofridas pelos timorenses durante a ocupação nipônica na região:

Ao longo desta campanha, muitas cidades, vilas e aldeias foram destruídas pelos bombardeamentos, tanto dos Aliados como dos Japoneses. Mas o pior ainda estava para vir. Quando em Fevereiro de 1943 as tropas australianas foram evacuadas, os Timorenses continuaram a luta e a sua derrota no final do ano teve como consequência os Japoneses cobrarem um tributo brutal pelo seu apoio aos Aliados. Em áreas nas quais os Australianos tinham estado activos, aldeias foram queimadas e famílias executadas. A população foi realojada e sujeita a entregas obrigatórias de comida aos Japoneses. $\mathrm{Na}$ altura da rendição japonesa, cerca de 60.000 timorenses, isto é, 13 por cento da população tinha morrido em consequência da guerra. (TAYLOR, 1991:44)

De início, Ruy Cinatti atuou como secretário do governo português, em Díli e, nos últimos meses de 1947, passou a atuar como agrônomo, percorrendo o território timorense. Com o levantamento realizado sobre o solo e a vegetação na região, Cinatti colheu material para sua tese de licenciatura, defendida em Lisboa em 1951. Já nessa época, passava a escrever suas poesias sobre Timor e os timorenses. Seus poemas desse período falam sobre a paisagem de Timor, sobre o povo timorense, suas crenças e sua diversidade cultural.

Mesmo depois de retornar a Portugal, Cinatti continuou escrevendo sobre Timor-Leste, pois, com o passar do tempo, ao conhecer melhor a 
população, sentiu profunda identificação com aquele povo, tendo realizado várias viagens à ilha. Em 1966, Ruy Cinatti esteve em Timor-Leste pela última vez e, a partir de seu envolvimento com o povo, procurava conhecer seus desejos, suas necessidades e sobretudo o sofrimento dos timorenses, causado pelo sistema colonial português. De certa maneira, Cinatti previu o que poderia acontecer na região quando Timor não estivesse mais sob o jugo dos portugueses, conforme relata em entrevista ao jornal $A$ Luta:

O processo de descolonização enfermou dos mesmos defeitos que já eram notórios no processo de administração do regime anterior ao 25 de Abril embora muito mais graves e se lhes tenha mudado o sinal. No fundo, a mesma irresponsabilidade, fruto da ignorância e de propósitos disparatados que, por o serem, muitas vezes se contradisseram, sem que a promoção dos Timorenses ao seu próprio destino fosse o motivo primacial daquele processo. No fundo, um "lavar as mãos" como Pilatos, mas não em água limpa... (Entr.1975b) (STIWELL, 2000:373).

Nessa época, de fato, havia alguma relutância por parte dos timorenses em relação ao sistema colonial português, mas as principais revoltas haviam sido contidas. Ruy Cinatti, convivendo com os dois mundos, tinha um olhar diferenciado sobre Timor, mesmo sendo um português a cargo da Administração do seu país.

O autor, por meio de seus escritos, questionou a falta de interesse no processo de colonização português frente ao já fragilizado povo timorense, que teve seu território devastado:

(...) talvez, reflectia uma das minhas mais cruciais verificações - a de que nada poderia fazer em prol dos Timorenses se a minha actuação se não processasse em pé de igualdade, mediante um consenso cultural que minorasse as diferenças civilizacionais (...) O processo, por demais complexo em teoria, parecia-me (ainda me parece) extremamente simples na prática, desde que os agentes - passivos-activos, activospassivos - se compenetrassem de que a dádiva de si mesmos tem que estar acima de todos os interesses colectivos ou individuais. (CINATTI, 1974:149)

Entretanto, muitas vezes, Cinatti também se posiciona claramente do lado do colonizador, pois fazia parte do sistema predominante na região após a 
desocupação japonesa. $O$ domínio português frente à população timorense, após a saída dos japoneses de Timor, é assim narrada:

Com a saída dos Japoneses, os Portugueses voltaram, na esperança de poderem continuar o padrão de governo colonial tradicional. $\mathrm{O}$ controlo foi implacavelmente retomado. A infra-estrutura económica foi reconstruída com trabalho compulsório, aumentando os poderes dos chefes no sentido do recrutamento de trabalho forçado nos seus sucos. A utilização de trabalhadores de cada suco durante pelo menos um mês por ano na construção de estradas, edifícios e instalações portuárias levou a um declínio na produção agrícola, já que pelo menos alguma parte da população masculina estava sempre ausente da aldeia. Enfrentando um declínio económico em casa, aliado a um isolamento internacional devido à sua falta de ajuda à política de Franco, os Portugueses foram forçados a apoiar-se nesse trabalho compulsório para a reconstrução da sua distante colónia. (TAYLOR, 1991:44)

O trabalho físico, cada vez mais degradante, deixava o povo ainda mais debilitado. Após o reestabelecimento do sistema agrícola e econômico, os portugueses continuaram a impingir humilhações aos timorenses. Fora a degradação física, que então já era algo costumeiro, teve início a degradação moral aos timorenses. O sistema colonial era um sistema de escravidão e ainda havia a imposição das reverências, que deveriam ser prestadas aos cidadãos portugueses:

Uma descrição típica, feita por visitantes durante este período, foi dada por um membro do Australian War Graves Commission, que foi a TimorLeste em 1947: "Trabalho forçado debaixo de chicote é feito do nascer ao pôr do Sol e os colonialistas portugueses vivem com a mesma mistura de civilidade e brutalidade com que viviam há trezentos anos" (...) Com estas tarefas económicas e políticas básicas concluídas, 0 domínio português voltou-se para os seus objetivos antes da guerra. A produção de produtos agrícolas aumentou, foi permitida a participação no sistema político de alguns timorenses e a capacidade educacional foi alargada por meio das escolas católicas. Seguros da crença de que os movimentos de independência subvertendo o domínio colonial através do Sudeste asiático do pós-guerra, nunca se estenderiam à sua ordeira sociedade, os administradores aconselharam os Timorenses a fazerem mesuras ou saudarem sempre que encontrassem um português; tais práticas "feudais" tornavam-se bastantes embaraçosas para visitantes estrangeiros... (Idem, 1991:45) 
Cinatti, ao se ligar ao povo timorense, preferiu manter suas próprias convicções. Durante o tempo em que lá esteve, manteve íntima ligação com os naturais da ilha e assimilou suas tradições e seu modo de vida.

Ao final de duas décadas, Cinatti sabia que, pela ordem natural dos acontecimentos, haveria um processo de independência em Timor, embora não estivesse imbuído de espírito político ou partidário quanto a essa questão.

Pressentindo que algo grave poderia acontecer com a independência em Timor, Cinatti escreveu uma carta ao Diário de Notícias, relatando seus temores, mas tal carta nunca foi publicada. Peter Stiwell faz comentário sobre a carta e sua motivação, contudo não há menção sobre o conteúdo da mesma:

Um artigo sobre Timor no Diário de Notícias de 24 de Janeiro motiva uma longuíssima carta de dez páginas, até hoje inédita, sobre a situação naquele território. Por razões de extensão ou conteúdo, o jornal não a publicou". (STIWELL, 2000:372).

Dos vários livros escritos por Ruy Cinatti, destacamos Um cancioneiro para Timor e Paisagens timorenses com vultos, por falarem de perto sobre os timorenses em seu território. No primeiro, concluído em 1968 e publicado em 1980 pela Editorial Presença, livro dedicado a Alberto Osório de Castro, encontramos alguns textos referentes à cultura da região e doze poemas. No segundo, escrito em 1970 e publicado em 1996 pela Editora Relógio D’Água, com trinta e um poemas, também há textos que refletem sobre a política vigente em Timor na época.

Apresentamos neste trabalho quatro dos seus poemas sobre Timor. $\mathrm{O}$ primeiro relata a pobreza e a situação precária vividas na região e o segundo fala sobre Alain Gerbault, o navegador solitário que morreu na ilha. Anos mais tarde, o último poema inspiraria o escritor Luís Cardoso a escrever o romance Requiem para o navegador solitário (2007): 


\section{Propósito Inadiável}

O que magoa é ver o pobre timorense esquálido beber

Água do pântano,

onde se escoam lixos,

comer poeira

e saudar-me, quando

rodo na estrada,

deus ocioso.

Tantos e tantos outros,

timorenses esquálidos,

olham-me como se dever fosse

abrir covas,

plantar repasto

de milho, arroz e carne,

encher copos vazios,

de bebedeira e sonho,

que não magoe,

mortifique o ócio

reanime o tempo.

Fugir é melhor que prometer

esperança em melhores dias.

Fugir é atrasar

o discurso limite

travado pelas rodas

da dúvida maníaca.

Eu não prometo nada.

Invoco os montes

feridos pela luz,

o mar que me circunda

em Díli terra-tédio e de má gente. 


\author{
Afino-me pelo timbre \\ Limpo das almas \\ Dos timorenses esquálidos \\ Que me soletram vivo. \\ E sigo, \\ limpo na alma e no rosto, \\ sujeito à condição que me redime. \\ Os Timorenses só terão razão \\ quando me matarem.
}

No poema acima, Ruy Cinatti faz alusão à pobreza e à miséria que encontrou em Timor, quando ali chegou, bem como à condição do timorense, que descreve como "pobre" e "esquálido", retratando a situação precária da população que "bebe água do pântano, onde se escoam lixos".

Ao longo do poema, após qualificar o povo de Timor, refere-se à situação política, afirmando que: "Fugir é melhor que prometer esperança em melhores dias" e a seguir se refere à própria condição perante à pobreza e à situação política em Timor, na quarta estrofe. De forma crítica, Ruy Cinatti menciona a fuga portuguesa, quando da invasão japonesa, e também aponta para a própria impotência, pois, como português, nada pode fazer para amenizar o sofrimento e a miséria do povo. E finaliza: "Os Timorenses só terão razão / quando me matarem", colocando-se como representante do colonialismo português, que explora o povo timorense.

\title{
Visão
}

Para Alain Gerbault, falecido em Díli

Levanto as minhas mãos repletas de água.

Amanheceu!

Sonho no mar sereias: algas,

Corais limosos... Eu acordava

Entre aguaceiros límpidos. Pinhais, 
Pássaros, flores, penumbra e arcada de árvores

- Momento

Que ao de leve anotava.

Serenamente explorava

Apelos e miragens.

Era o mar cheio de estrelas,

Barcos partindo para não sei onde.

Ondulações magnéticas, antenas.

Ansiedade...

Eram ilhas

Hercúleas: coroas

Vegetais sobrenadando

Altos castelos submersos e, apenas,

("Sepultem-me no mar, longe de tudo"),

Alain,

Entre vagas, velas e gaivotas.

Levanto as minhas mãos repletas de água.

Amanheceu!

Este poema, dedicado a Alain Gerbault, o navegador solitário, que, após dar a volta ao mundo uma vez, completou a façanha pela segunda vez, vindo a adoecer e morrer em terras timorenses, declara o amor à natureza de Timor e tematiza o momento de morte do navegador. O título do poema, "visão", assinala o momento final da vida do navegador solitário. As palavras "mar", "sereia", "algas", "corais limosos" presentificam o desejo que Alain Gerbault tinha de ser sepultado no mar. O verbo final, "amanheceu", representa o momento preciso da morte num tempo acabado.

A obra de Ruy Cinatti é considerada muito significativa para a literatura timorense de língua portuguesa. O autor, que fez um pacto para se tornar timorense, descrito no poema "Os vínculos portugueses", procurou, em suas obras, descrever Timor como se timorense fosse. Em princípio, não há como enquadrar seus poemas em qualquer vertente estética específica, quer 
portuguesa, quer brasileira, ainda que sua dicção política seja claramente filiada ao que genericamente designamos de poesia moderna.

No livro Um cancioneiro para Timor, concluído em 1968 e publicado anos mais tarde, no qual homenageia um desconhecido poeta timorense que, presumivelmente, tombou durante a guerra, Ruy Cinatti reúne poemas que nomeadamente descrevem Timor geograficamente e outros que cultuam 0 modo de vida e rituais perpetuados pelos mauberes, incluindo aí também suas experiências em Timor:

\section{A Natureza e a Cidade \\ Chove, chove, sem parar, na berma da minha aldeia. \\ $O$ vale adensa a neblina afundada na ribeira.}

Um veio d'água perdeu-se afundado na ribeira.

A luz do sol encantou a terra verde, orvalhada. Uma brisa perpassou suavemente na várzea.

$\mathrm{O}$ arroz rumorejou suavemente na várzea.

Quem na montanha se abriga tem tempo para pensar, enquanto a chuva desliza que a trovoada é o mar.

Os da praia já não dizem que a trovoada é o mar. 
Muitas cidades e ruas.

Luzes me enganam, talvez.

Díli, à noite, encandeia.

De manhã, ninguém a vê.

É tal qual a minha aldeia.

De manhã, ninguém a vê.

Nesse poema Ruy Cinatti faz uma comparação entre campo e cidade em Timor e, após, compara as terras timorenses às aldeias portuguesas. $\mathrm{Na}$ primeira parte descreve a chuva na aldeia e, assim, faz alusão aos benefícios para aqueles que não vivem na cidade, exaltando as características campesinas, bem como o modo de vida daqueles que escolhem um local mais retirado para viver:

\footnotetext{
"Quem na montanha se abriga

tem tempo para pensar,

enquanto a chuva desliza

que a trovoada é o mar"
}

Mais adiante, o autor fala claramente sobre Díli, descrevendo a cidade timorense tal qual uma aldeia:

"Díli, à noite, encandeia.
De manhã, ninguém a vê.
É tal qual a minha aldeia.
De manhã, ninguém a vê"

O pacto de sangue realizado entre Ruy Cinatti e um timorense é o tema do poema abaixo. 


\section{Os vínculos portugueses}

Meu irmão, meu irmão branco,

de cor, como eu também!

Aceita a minha aliança.

Bebe o meu sangue no teu.

Se te sentires timorense,

bebe o teu sangue no meu.

Lenço enrolado nas mãos,

apertadas, pele na palma.

Não o quero maculado.

Quero-lhe mais que à minh'alma.

É penhor de uma aliança.

Quero-lhe mais que à minh'alma.

Tenho o meu coração preso

a um símbolo desfraldado;

a um desenho atribuído,

pelas minhas mãos hasteado.

Não piso a sombra de um símbolo

pelas minhas mãos hasteado.

No Tata-Mai-Lau aprendo

alturas que ninguém viu

na terra de Português.

Hasteei-Ihe uma bandeira.

Timor deu a volta ao mundo.

Hasteei nele a bandeira. 
$\mathrm{O}$ ritual do pacto de sangue tem por finalidade transformar o autor em um legítimo cidadão timorense. É, portanto, uma aliança realizada por um europeu para procurar adentrar aos costumes do "outro", na busca de vivenciar o que seria de fato a identidade timorense. O sangue, que representa a vida, é citado em primeiro lugar, como primeira condição para que o europeu tenha a qualidade do "autóctone":

"Aceita a minha aliança.

Bebe o meu sangue no teu.

Se te sentires timorense, bebe o teu sangue no meu.

Lenço enrolado nas mãos, apertadas, pele na palma. Não o quero maculado.

Quero-lhe mais que à minh'alma".

Adiante, após o pacto realizado, refere-se ao monte Tata-Mai-Lau, ou Ramelau, segundo os indonésios, que é o monte mais alto em Timor e também um local sagrado:

\footnotetext{
"No Tata-Mai-Lau aprendo

alturas que ninguém viu

na terra de Português".
}

O pacto de Cinatti pode não Ihe ter garantido e o entendimento do que vinha a ser um timorense de fato, mas certamente fez com que seu vínculo pessoal e afetivo com o povo do Timor se aliasse tanto no pacto, quanto no poema que escreve sobre o mesmo, dando vida literária à possibilidade de um vínculo verdadeiro profundo entre duas culturas tão distintas. 


\subsection{Independência política e literária}

E naquelas páginas confirmei: pela mão de um homem se escreve Timor

Mia Couto

Em suas palavras, Mia Couto, escritor moçambicano que prefaciou o livro Mar meu, de Xanana Gusmão, sintetiza o que leu e aprendeu sobre os escritos produzidos em Timor e pelos timorenses, à época da independência, seguida da invasão e do massacre do exército indonésio ao território de Timor. O período da independência foi marcado pela luta armada configurada em dois momentos: num primeiro momento, a guerra civil entre os partidos que defendiam a independência de Timor de Portugal; aqueles que defendiam a continuidade do domínio português; e ainda os que defendiam a anexação à Indonésia; e, num segundo momento, a invasão do exército indonésio que iniciou o massacre em Timor.

Os poemas que surgiram na ocasião perpetuam, acima de tudo, o contexto histórico no qual foram escritos, situações vivenciadas e os sentimentos gerados a partir da instabilidade e da inconstância provocadas naquele momento. Encontramos, assim, além das descrições geográficas e físicas, relatos de conflitos, mudanças forçadas e persistências dos timorenses quando e onde os embates tiveram lugar, a gênese dos poemas que falam de perto sobre a busca identitária de um povo e a travessia percorrida por esse povo, desde a chegada dos primeiros colonizadores.

Sobre a busca identitária, no decorrer dos anos, verifica-se a ascensão da elite timorense, que se coloca na sociedade conforme as necessidades imperativas no momento. Há a transformação da sociedade, a formação dos grupos, os que aderem à vontade de permanecer sob o jugo português, os que querem independência imediata e ainda aqueles que aceitam a anexação à Indonésia; tudo de acordo com o histórico vivenciado pelo grupo social distinto, durante a colonização e a ocupação. Conforme afirma Stuart Hall: 
Uma vez que a identidade muda de acordo com a forma como o sujeito é interpelado ou representado, a identificação não é automática, mas pode ser ganhada ou perdida. Ela tornou-se politizada. Esse processo é, às vezes, descrito como constituindo uma mudança de uma política de identidade (de classe) para uma política de diferença. (HALL, 2006:21)

Ora, em parte, é mister observar que, embora os timorenses, desde a chegada dos ocidentais, tenham sido considerados por esses um só povo, Timor, como nação, abrigava vários povos, que falavam línguas distintas, conforme sua organização interna. Sem dúvida nenhuma, após a colonização portuguesa, que franqueou cargos administrativos aos autóctones e, destarte, privilegiou os filhos dos nativos detentores desses cargos, houve a cisão efetiva, uma separação. Uns desejavam a independência e outros queriam a dominação portuguesa, mesmo que apenas em termos administrativos.

A guerra civil deflagrada no limiar do processo de independência denota a ruptura na sociedade timorense como um todo, tendo em vista os acontecimentos pregressos. Essa questão, porém, intensificou-se quando da invasão por parte dos indonésios.

Quando ocorreu a invasão indonésia, houve forte resistência por parte do povo timorense, que não possuia armamento bélico para fazer frente ao combate. Diante de alguns aspectos estudados recentemente, talvez uma das questões mais importantes seja a da resistência timorense diante do inimigo.

Sobre a invasão de 1975 por parte dos indonésios, documentos recentes afirmam a participação da Austrália e Estados Unidos. John G. Taylor, em seu livro, Timor - A história oculta, apresenta o contexto no qual se deu a anexação de Timor pela Indonésia e os motivos que levaram os indonésios a empreender essa luta, com a finalidade de anexar o território timorense. Nessa obra, Taylor relata também os horrores sofridos pelos timorenses quando da colonização portuguesa que, em princípio, buscava apenas explorar o território. O sistema colonial português em Timor, descrito de maneira diferenciada por alguns historiadores, têm seus métodos revelados no relato contundente de Taylor. 
De fato, a colonização portuguesa em Timor, naturalmente, promoveu muitos estragos. Ademais, os costumes e o modo de vida da população nativa foram afetados, devido à falta de compreensão dos colonizadores quanto ao modo de vida já estruturado em Timor. Assim, quando da chegada dos europeus, os timorenses foram escravizados e a religião católica imposta, ao ser introduzida a língua portuguesa de maneira não sistemática à época.

O território timorense, então negligenciado pelos portugueses, contava apenas como mais uma colônia ultramarina. Isso perdurou durante o regime salazarista, que, ao lidar com a descolonização em seus territórios, atuou de maneira similar em Timor na década de 1970. Com a queda do regime salzarista, partidos políticos foram criados em 1974, em Timor, como descreve Márcio Gagliato:

[...] com a liberdade política propiciada pela Revolução de Abril, em Portugal, e com os desdobramentos dos contatos políticos com outros movimentos de libertação, criaram-se, a partir de maio de 1974, as coligações políticas em Timor, a UDT - União Democrática Timorense, a ASDT - Associação Social Democrática Timorense e a APODETI Associação Popular Democrática de Timor. (GAGLIATO, 2006:19).

A referência aos vários movimentos independentistas desde 1959, remonta à revolta chefiada por Dom Boaventura, em 1911, em Timor, pois esses movimentos foram sufocados pelo governo português. Mais tarde, os movimentos revolucionários em Timor seriam também reprimidos pelos portugueses, que queriam evitar outras questões dessa natureza. Segundo José Carlos Adão, esse momento propiciou o surgimento de uma classe de políticos esquerdistas, desejosos de ver Timor-Leste liberto:

A geração de políticos timorenses que surgiu nos inícios dos anos 70 , mais proactiva politicamente, poderá ter tirado lições dos acontecimentos e das consequências. Começaram a publicar os primeiros artigos de cariz político no suplemento da Seara no Boletim Eclesiástico da Diocese de Díli, tendo a publicação sido encerrada pela PIDE a 10 de fevereiro de 1973. Nela escreveram figuras de Timor como Ramos-Horta, Nicolau Lobato, Mari Alkatiri, Francisco Xavier do Amaral, Domingos de Oliveira, Francisco Borja da Costa e Manuel Carrascalão. (Gunn, 1999 apud ADÃO, 2008:24) 
O primeiro partido político em Timor, a União Democrática Timorense (UDT), foi fundado em 11 de maio de 1974 e pretendia promover a manutenção dos laços entre Timor e Portugal, ou seja, não haveria independência total. Esse partido era formado por funcionários da administração, nomeados por Portugal, e seus filhos, que tinham certos privilégios no território; era um partido conservador, que defendia uma autonomia progressiva sob a bandeira de Portugal (grifo do autor) (ADÃO, 2008:25). Logo após, surgiu a Associação Social Democrática Timorense (ASDT) e a Associação Popular Democrática de Timor (APODETI).

Em 11 de setembro de 1974, a ASDT alterou sua nomenclatura para Frente Revolucionária de Timor Leste Independente - FRETILIN. Este partido desejava a independência imediata e total do jugo dos portugueses. Outro partido minoritário, que simpatizava e apoiava a anexação de Timor à Indonésia, era a Associação Popular Democrática Timorense - APODETI.

A intenção de todos, no início, era a de promover a independência de Timor-Leste por meio de processo pacífico, em acordo, sem derramamento de sangue. Houve uma coligação entre a FRETILIN e a UDT, com o intuito de enfraquecer a APODETI, pois nem FRETILIN, nem UDT queriam a anexação à Indonésia. Unidos contra a APODETI, poderiam alcançar o ideal de Timor independente.

Em 11 de agosto de 1975, a UDT deu um golpe de Estado e, mesmo de maneira precária, sem reconhecimento de outros países, declarou a independência em relação a Portugal. Entretanto, a instabilidade interna e a falta de apoio internacional permitiu o crescimento dos interesses indonésios, que, em 7 de dezembro de 1975, invadiram Timor-Leste. Os indonésios, sim, contavam com o apoio e com o material bélico de outras nações e, assim, começou a ocupação.

A questão da tentativa de refrear o crescimento populacional em Timor, por parte dos militares indonésios, num plano de "destimorização" é levada a efeito. Mulheres em Timor são operadas e recebem medicamentos para limitar o crescimento populacional e, ao mesmo tempo, as timorenses são estupradas pelos indonésios, que impõem sua cultura e seu idioma, numa tentativa de "repovoar" o local com a sua gente. 
A língua portuguesa foi eliminada das escolas pelos indonésios, pois a estratégia primeira foi a de acabar com tudo que se reportasse à colonização portuguesa. Além da língua, a religião católica também passou a ser estigmatizada, já que era legado dos portugueses, sendo os indonésios de maioria muçulmana. À época da independência, já um bom número de habitantes de Timor tinha acesso aos seminários e às igrejas católicas e, com o início dos dias de terror, muitos se refugiaram nas montanhas. As milícias de resistência se formaram e surgiu, assim, o desejo de escrever, em forma de poesia, as agruras da guerra e o desejo de libertação do jugo indonésio. Aqueles que militavam pela causa libertária em Timor-Leste formaram, inicialmente, o grupo de poetas que deixaram seus escritos e com eles apresentaram a nós um Timor muito diferente daquele representado por Alberto Osório de Castro e Ruy Cinatti. 


\subsection{Literatura engajada: a poesia dos militantes}

É no texto, em sua produtividade artística, que o escritor engajado vai resgatar as carências que Ihe servem de referencial.

Benjamin Abdala Junior

O professor Benjamin Abdala Junior, em seu Literatura, História e Política, aborda questões referentes ao comunitarismo e à literatura engajada. Dessa perspectiva, o autor nos fala sobre os horizontes da literatura portuguesa em Timor "como reação comunitária" (ABDALA JUNIOR, 1999:17).

Antonio Candido, em Literatura e Sociedade (1965), afirma que a "obra depende estritamente do artista e das condições sociais que determinam a sua posição" e ainda que "os valores e ideologias [do autor] contribuem principalmente para o conteúdo, enquanto as modalidades de comunicação influem mais na forma" (CANDIDO, 1965:35). Certamente, para o escritor, a liberdade é fundamental. Portanto, os embates travados pelo homem, quando a liberdade Ihe é tolhida, afetam profundamente aqueles que escrevem e usam da literatura como um meio de propagar suas ideias.

Nesse mesmo sentido, Sartre salienta a importância da liberdade para os literatos:

Pois não se pode exigir de mim, no momento em que percebo que minha liberdade está indissoluvelmente ligada à de todos os outros homens, que eu a empregue para aprovar a servidão de alguns dentre eles. Assim, quer seja ensaísta, panfletário, satirista ou romancista, quer fale somente das paixões individuais ou se lance contra o regime social, o escritor, homem livre que se dirige a homens livres, tem apenas o único tema: a liberdade. Segue-se que qualquer tentativa de subjugar seus leitores o ameaça em sua própria arte. (SARTRE, 2004:27) 
Mais adiante, o mesmo autor fala sobre a escrita engajada, salientando que não basta ao autor apenas escrever. Às vezes, é necessário que esse mesmo escritor tome das armas, para defender sua liberdade:

\begin{abstract}
No mesmo momento, outros - felizmente a maioria - compreendiam que a liberdade de escrever implica a liberdade do cidadão. Não se escreve para escravos. A arte da prosa é solidária com o único regime onde a prosa conserva um sentido: a democracia. Quando uma é ameaçada, a outra também é. $E$ não basta defendê-las com a pena. Chega um dia em que a pena é obrigada a deter-se, e então é preciso que 0 escritor pegue em armas. Assim, qualquer que seja o caminho que você tenha seguido para chegar a ela, quaisquer que sejam as opiniões que tenha professado, a literatura o lança na batalha; escrever é uma certa maneira de desejar a liberdade; tendo começado, de bom grado! Ou à força você estará engajado. Engajado em quê? Perguntarão. Defender a liberdade, afirma precipitada. Trata-se de tornar-se o guardião dos valores ideais, como o "intelectual" de Benda ${ }^{30}$ antes da traição, ou será que é a liberdade concreta e cotidiana que é preciso proteger, tomando partido nas lutas políticas e sociais? A questão se liga a outra, simples na aparência, mas que nunca é levantada: "Para quem se escreve?" (SARTRE, 2004:53) (...) À primeira vista, não haveria dúvida: escreve-se para o leitor universal; e vimos, com efeito, que a exigência do escritor se dirige, em princípio, a todos os homens. (SARTRE, 2004:55)
\end{abstract}

É dentro desse espírito que a poesia, em Timor, floresce em português e em tétum, a partir dos componentes que formavam a resistência timorense. Algumas poesias são publicadas nos dois idiomas: em tétum, por ser o idioma pátrio, que está mais próximo à cultura timorense para expressar os sentimentos daquele povo, por ser o idioma materno no qual se aprende a balbuciar as primeiras palavras; em português, por ser o idioma escolhido para debater as questões políticas, a língua da cristandade, e a língua internacional para que o mundo todo leia, ouça e saiba que há um povo que está sendo destruído e tem ameaçada a sua integridade física, moral, bem roubada sua identidade nacional. A poesia em questão retrata, sobretudo, as agruras da guerra. É uma poesia revolucionária também no que diz respeito à escolha do idioma português, por ser uma língua de pouco prestígio internacional, mas que contava com muitos intelectuais portugueses que não silenciaram acerca da ocupação indonésia.

\footnotetext{
${ }^{30}$ Sartre faz alusão a Julien Benda, que defendia o não engajamento do escritor, que deveria apenas se reportar à Justiça, ao Juízo e à Razão em seus escritos (SARTRE, 2004:53).
} 
Sobre as questões linguística e religiosa, que estão lado a lado, podemos constatar, segundo afirma Sakamoto:

Durante o período colonial, não havia uma sintonia entre a Igreja Católica e os timorenses. Menos de um terço da população professava a fé do Vaticano, enquanto a grande maioria ainda mantinha os rituais animistas e o culto aos antepassados. O catolicismo que foi um dos principais instrumentos portugueses na conquista do território, desde a chegada dos dominicanos, ainda não se via como parte integrante de Timor. Durante a Segunda Guerra, dezenas de padres e freiras fugiram da ilha para a segurança em Portugal ou na Austrália - deixando à população à própria sorte contra japoneses. (SAKAMOTO, 2002:47)

Ademais, após a invasão por parte da Indonésia, a fuga de timorenses e religiosos portugueses para as montanhas ocorreu em massa. O convívio dos religiosos com a população passou a estreitar a relação entre eles. A ocorrência de massacres durante a repressão fazia com que o povo acorresse à igreja católica em busca de refúgio. O acolhimento oferecido pela igreja opunha-se à imagem do muçulmano, representada pelo soldado indonésio.

Outra questão interessante durante os anos de repressão indonésia foi a adoção da Pancasila ${ }^{31}$ na região, o que permitia, em seus princípios, a manutenção da religião católica. Desta forma, os princípios da Pancasila aplicados em Timor eram divulgados em sua totalidade em todas as regiões.

Assim, os adeptos da religião católica multiplicaram-se, sobretudo à época do massacre promovido pelos indonésios, pois os templos católicos assumiram além da função religiosa, lugar social de destaque.

Os meios religiosos cristãos eram propícios à população timorense, até como abrigo, para que os timorenses pudessem se refugiar e se resguardar dos abusos do exército indonésio. Portanto, a igreja, seu templo, passou a ser local de encontro para reuniões e também os membros do clero eram, em sua maioria, auxiliares dos membros da resistência timorense.

\footnotetext{
${ }^{31}$ Pancasila, ou cinco princípios, conforme a tradição indonésia, resumia-se na crença em um Deus supremo, justiça e civilidade entre as pessoas, na preservação da unidade na Indonésia, na democracia através do debate e do consenso entre representantes e na justiça social para todos. O principal objetivo desse conjunto de regras era suprir a demanda da comunidade muçulmana por um Estado islâmico e, ao mesmo tempo, encontrar um denominador comum para todas as ideologias existentes na Indonésia.
} 
Em entrevista a Adelino Gomes, o padre José Felgueiras, missionário jesuíta, afirma que a igreja exerceu papel acolhedor durante as décadas de terror imposto pelos indonésios. Ressalta, sobretudo, a figura do invasor muçulmano, que ficou gravada na mente daqueles que eram atacados. As ações dissimuladas, tais como a promessa de não mexer com a religião e realizar o contrário, feitas por parte do inimigo, depois eram descobertas pelo povo que, oprimido, morria sem defesa ${ }^{32}$ (GOMES, 2004:307).

Durante o período, a produção textual em poesia deve ser ressaltada, por estar intimamente ligada aos fatos históricos. Entre os poetas timorenses, merecem destaque Fernando Sylvan e Xanana Gusmão, sem contar João Aparício, autor contemporâneo, que atua ainda no consulado de Timor em Portugal. Todos com livros publicados, seus escritos expressam sobretudo as barbáries cometidas durante a invasão indonésia ou o sentimento de impotência diante dessa barbárie. Escritos em português, o tétum foi mesclado na composição dos poemas, os quais denotam o sentimento arraigado de amor à cultura e à tradição do povo timorense. Dos escritores acima citados, vale conhecer alguns poemas, quase todos da época da repressão, após a invasão indonésia.

A coletânea Enterrem meu coração no Ramelau foi publicada pela União dos Escritores Angolanos, em 1982, e reúne poemas de oito autores, Fernando Sylvan, Borja da Costa, Eugénio Salvador Pires, José Alexandre Gusmão, Oky do Amaral, M. Leto, Mali Manek, Jorge Lauten, além de poesias tradicionais. Esses são os poetas mais famosos de Timor-Leste, pois, sendo uma literatura incipiente, alguns escritores ainda não tiveram oportunidade de publicar seus trabalhos.

\footnotetext{
32 "Exigir-se que as cicatrizes desapareçam, que se esqueçam 25 anos de espancamentos, de famílias exterminadas, de bens totalmente perdidos? Quem foi que acolheu o povo quando este perdia a casa, quando o filho perdia o pai, quando um pai via a filha violada? A Igreja. Depois, não se esqueça de que os invasores eram indonésios e que estes são 90 por cento muçulmanos. Logo, para o povo, o invasor era muçulmano. O povo praticamente não conhecia o islamismo. Havia 500 em Comoro, até se davam bem. Um deles era o motorista de D. Jaime (Garcia Goulart, antecessor de D. Joaquim Ribeiro). Mas, quando foi a invasão, os tanques entraram em Díli por Comoro, não foi pela Areia Branca. Depois, esmagaram igrejas, esborracharam imagens dos santos. O povo viu aquilo tudo. Disseram ao bispo que não vinham atacar a religião, mas invadiram, roubaram, esmagaram. Logo nos primeiros dias da invasão em Cai-Coli, junto do edifício da universidade, metralharam toda a gente que tivesse qualquer objeto ou sinal ou dissesse uma palavra que Ihes lembrasse a Fretilin." (GOMES, As flores nascem na prisão, 2004:196).
} 
Da referida coletânea, escolhemos para análise um poema de Jorge Lauten, pseudônimo de um autor ainda desconhecido. O poema escolhido, de alta significação, que sintetiza o sentimento dos que vivenciaram as perdas em Timor e sofreram o exílio, chama-se "Enterrem meu coração no Ramelau" e dá título ao livro:

\section{Enterrem meu coração no Ramelau}

Que faço eu neste quarto de madeiras húmidas neste país distante? As pálpebras apertam-se como duas lâminas e impedem-me o sono. Lá longe, no país de Timor, na profundeza do mar, o molusco bivalve abre docemente os lábios e serve os últimos resíduos de luz.

Oh, assim também eu gostaria que esta memória não me afogasse em catadupas.

Entreabro os olhos. Os elétricos passam como gaiolas acesas desertas nestas ruas secundárias de Lisboa. Morre-me o intento de abrir as venezianas à luz da madrugada. Cambaleio no quarto. Na minha mão um frasco de perfume barato comprado num drugstore de Austrália. Oh, sei que adorarias este perfume, e estou a ver-te recebê-lo com o teu sorriso adolescente. Adorarias este perfume, Elisa, se estivesses viva, se não te tivessem metralhado o peito, o desenho duma borboleta de sangue sobre os seios morenos.

Oh Suharto, mira-te as últimas vezes no mármore preto do chão do teu palácio. Terás a morte na saúna do teu sangue. Esqueces que a alma de Timor é uma couraça, esqueces que somos filhos do grande crocodilo que cruzou o oceano.

O Tata Ramelau volatizou-se no nevoeiro de gaz. O seu espírito espera-vos, soldados doutras pátrias, em cada esquina de Dili, em cada curva da estrada, em cada pastilha elástica que mastigam suados de medo.

Estou aqui e penso: nem a morte nos pode juntar: vocês morrem pela ordem e pacificação na 27 a província e nós morremos pela nossa pátria independente.

Ainda me lembro em fins de Novembro, uma criança corria na areia fina da praia de Dili: que vento Ihe apagou as pegadas de criança, que morte lhe tolheu os passos? A todos os refugiados do Jamor perguntei por este meu filho de olhos cor de Timor. Em cada rosto um mapa de passos perdidos nas rugas de areia dos exilados.

Abro o armário de madeira húmida e visto uma camisa lavada que me deram em Port Darwin. Abro a porta para a terra estrangeira e o frio de Janeiro corta-me a pele. Fecho a porta como se enterrasse o meu coração no cume do Ramelau.

O texto revela a vivência do exílio juntamente com o sofrimento de quem presenciou os horrores e as atrocidades da repressão indonésia em Timor. Dividido em sete partes, traz como eu lírico alguém que vive longe de Timor e sofre de longe os horrores que sofrem os timorenses. Compara-se a um 
molusco, em processo metafórico. Evoca os soldados de outros lugares, fazendo alusão à luta contra a anexação de Timor à Indonésia. No final, o eu lírico movimenta-se: "abro a porta para a terra estrangeira e o frio de Janeiro corta-me a pele" e encerra desejando que seu coração seja enterrado no Monte Ramelau. A forma inusitada do poema faz alusão ao momento vivenciado pelo eu lírico, que, dividido, gostaria de estar em seu local de origem. Ao mesmo tempo, essa forma do poema cria a imagem da invasão, gerando uma composição sem harmonia visual, incomum na maioria dos poemas.

De Francisco Borja da Costa (Fatu Berliu, outubro 1946 - Díli, dezembro 1975), assassinado um dia após a invasão indonésia, não chegou até nós um livro completo, restaram apenas poemas esparsos, que serviram como protesto vivo de um autor que se transformou em herói e símbolo de coragem para os timorenses. Seus poemas todos retratam a repressão do invasor e a esperança de libertar-se desse jugo. Sobre a obra do autor, podemos dizer que, embora sua produção artística seja diminuta, devido a sua curta existência, seus poemas foram publicados, além de em Timor-Leste, na Austrália, em Moçambique, Angola e Portugal ${ }^{33}$.

\section{Foho Ramelau ${ }^{34}$}

Eh! Foho Ramelau, foho Ramelau eh!

Sá bé as liu ó tutun, sá bé bein liu ó Iolon eh!

Tan sá timur oan hakruuk bei-beik?

Tan sá timur oan atan bei-beik?

Tan sá timur ulun sudur uai-uain?

Tan sá timur oan ata uai-uain?

\footnotetext{
${ }^{33}$ Segundo comentários de Artur Marcos, em seu livro Timor Timorense com suas línguas, literaturas, lusofonia (1995), ao destacar a poesia de autoria de Francisco Borja da Costa. Ainda, na Austrália, foi criada a Fundação Austronésia Borja da Costa, como referência de centro de pesquisa para a cultura timorense na Austrália.

${ }^{34}$ Os poemas Foho Ramelau e Kdadalak, constantes neste trabalho, foram compilados segundo transcrição de Artur Marcos, em seu livro Timor Timorense com suas línguas, literaturas, lusofonia (1995), assim como suas respectivas traduções para o português.
} 
Hadér rai-hun mutin ona la!
Hadér loro foun sa'e ona la!

Loke matan loro foun too iha ó knuak

Loke matan loro foun iha ita rain

Hadér kaer rasik kuda talin eh!

Hadér ukun rasik ita rain eh!

\section{Monte Ramelau (1974)}

Oh! Monte Ramelau, Monte Ramelau!

Que é que é mais alto que o teu cume!

Que é que é mais magestoso que a tua imponência!

Porque é que a cabeça do timor há-de-curvar eternamente?

Porque é que o timor há-de ser escravo para sempre?

Acorda que a madrugada já desponta

Acorda que o novo sol já desponta

Abre os olhos que o novo dia já chegou à tua aldeia

Abre os olhos que o novo dia já chegou à nossa terra

Acorda e tome conta do teu destino

Acorda e governemos nós próprios a nossa terra

Escrito em versos livres, o poema contém onze versos, distribuídos visualmente em pares, após a primeira estrofe com o vocativo, invocando o Monte Ramelau.

Ao citar o Ramelau como o ponto mais alto de Timor, são usados os adjetivos "magestoso" e "imponência" em oposição aos versos que se seguem: 
"Porque Porque é que a cabeça do timor há-de-curvar eternamente?/

Porque é que o timor há-de ser escravo para sempre?"

Em seguida, há a exortação imperativa a que o povo timorense não continue na escravidão, mas faça um movimento para despertar, com as frases: "acorda", "abre os olhos". Tal exortação é seguida de uma promessa de dias melhores, de um novo amanhecer. E, por fim, no último verso, o povo é conclamado a governar sua terra, sem interferência, sem intermediação "tome conta do teu destino".

\section{Kdadalak}

Kdadalak suli mutuk fila ué inan

Ué inan tan malu sá ben tahan

Nanuu timur oan sei hamutuk

Hamutuk atu tahan anin sut tasi

Anin sut tasi sut kabala

Sut ita mata laran ita kokut laran

Sut ita lun turu ita kosar turu

Susu Ita rai bokur ita isi bokur

KDADALAK SULI MUTUK FILA UÉ INAN

TIMUR OAN HAMUTUK TANE ITA RAIN 


\section{Regatos}

Regatos convergindo transformam-se em rios

Os rios juntando-se qual a força que se lhes opõe

Assim os Timorenses devem juntar-se

Devem unir-se para se oporem ao vento que sopra do mar

O vento que sopra do mar fustiga o trajo

Fere a vista e martiriza o dorso

Faz as lágrimas e o suor rolarem pelo chão

Suga a gordura da nossa terra e do nosso corpo

Regatos convergindo transformam-se em rios

TIMORENSES, UNIDOS, ERGAMOS A NOSSA TERRA

O poema acima, da autoria de Francisco Borja da Costa, é uma ode que exalta Timor-Leste. Em "Regatos", o próprio título do poema faz alusão ao choro. A metáfora do "vento" que "fere a vista e martiriza o dorso" e provoca ainda mais o choro, que "faz as lágrimas e o suor rolarem pelo chão", traz a imagem sofrida do povo timorense que já está em luta.

Segundo interpretação de Regina Helena Brito : "O poema afirma a intenção, do autor, de comparar a força da água com a união das pessoas, do povo timorense, pois um regado é insignificante, mas muitos tornam-se uma corrente, um rio". Assinala, também, a música Kdadalak de melodia suave e ondulante ${ }^{35}$.

Fernando Sylvan, nascido em Díli, em 26 de agosto de 1917, e falecido em Cascais, em 25 de dezembro de 1993, escreveu as seguintes obras: Vendaval (1942), Oração (1942), Os Poemas de Fernando Sylvan (1945), Sete Poemas de Timor (1965), Mensagem do Terceiro Mundo (1972), Tempo Teimoso (1974), Meninas e Meninos (1979), Cantogrito Maubere - 7 Novos Poemas de Timor-Leste (1981), Mulher ou o Livro do teu Nome (1982), A Voz

${ }^{35}$ Declarações da Professora Regina Helena Brito durante entrevista em junho de 2013. 
Fagueira de Oan Timor (1993). Foi homenageado em Lisboa, na ocasião do lançamento de seu livro A voz fagueira de Oan Timor. Dentre os vários discursos, na Universidade de Lisboa, houve uma homenagem feita em língua tétum pelo professor Luís Costa, linguísta e tradutor timorense, que compilou o Dicionário de Tétum-Português, lançado pela Editora Colibri, Lisboa, em 2000.

Ao prefaciar o livro A voz fagueira de Oan Timor, organizado por Artur Marcos e Jorge Marrão, publicado pela Editora Colibri, em Lisboa, Maria de Santa Cruz assim se refere ao poeta e aos escritos do autor:

Quase sempre heterométricos, os substantivados versos dos poemas de Fernando Sylvan aqui reunidos, em número muito restrito em cada poema, contam, como toda a sua retórica mas insistentemente, com as figuras de silêncio. A litotes, figura do classicismo por excelência, diznos apenas o bastante para excitar em nós a curiosidade de saber mais sobre os temas preferenciais: Timor, o povo Maubere, o amor por uma Mulher. (SYLVAN, 1993:5)

Do autor, destacamos o poema "Infância":

\section{Infância}

as crianças brincam na praia dos seus pensamentos

e banham-se no mar dos seus longos sonhos

a praia e o mar das crianças não têm fronteiras

e por isso todas as praias são iluminadas

e todos os mares têm manchas verdes

mas muitas vezes as crianças crescem

sem voltar à praia e sem voltar ao mar

(Enterrem meu coração no Ramelau, 1982) 
O poema faz parte do livro Enterrem meu coração no Ramelau, escrito com rimas mistas, pleno de metáforas, e simboliza a pureza das crianças num futuro incerto em Timor. "A praia e o mar das crianças não têm fronteiras", neste verso, o autor focaliza nos substantivos praia e mar o presente e o futuro, respectivamente. O substantivo praia e suas adjetivações: "praia dos seus pensamentos", "praia iluminada", fala sobre o presente permeado de sonhos e planos, que serão alcançados no mar, o futuro. O cumprimento dos versos e sua sonoridade remetem ao movimento incerto das ondas.

O autor Xanana Gusmão, líder da FALINTIL e depois FRETILIN, grupo armado que defendia a independência imediata de Portugal, nasceu em 20 de junho de 1946, em Manatuto, filho de um mestre-escola e de uma camponesa. Escreveu vários livros e, mesmo na prisão, compôs o livro de poesias $\mathrm{Mar} M e u$, no qual também aparecem gravuras de sua autoria.

Destacamos aqui alguns poemas de Mar Meu, com prefácio de Mia Couto, escritor moçambicano. Couto exaltou a força de combate do povo timorense, ressaltando a bravura do autor, ao se referir a Xanana como um autor engajado na luta pela libertação de Timor-Leste. Dessa forma, frente à decadência de valores entre os povos, que buscam valores materiais e o poderio político, em primeiro lugar, Mia Couto exalta a união do povo timorense, que abraçou a causa de independência em Timor com denodo. Em seu prefácio, a causa timorense e o livro de Xanana são assim tratados:

Timor parece erguer-se como prova contrária a estes sinais de decadência. Afinal, há alma para sustentar causas, erguer a voz, recusar alheamento. Uma nação distante se reassume como nosso lar, nossa razão, nosso empenho. $O$ sangue que se perde em Timor escorre de nossas próprias veias. As vidas que se perdem em Timor pesam sobre a nossa própria vida. Foi assim que li os versos de Xanana. E naquelas páginas confirmei: pela mão de um homem se escreve Timor. Um livro de Xanana Gusmão não poderia ser apenas um livro. Por via da sua letra se supõe falar todo um povo, uma nação. Há ali não apenas poesia mas uma epopeia de um povo, um heroísmo que queremos partilhar, uma utopia que queremos seja nossa. (GUSMÃO, 1998:6) 
Apresentamos, neste trabalho, o poema "Avô Crocodilo", que fala de perto sobre o tema Timor, recuperando o mito fundador da lenda do crocodilo, como veremos a seguir:

\section{Avô Crocodilo}

(Para Marta B. Neves, Lisboa)

Diz a lenda

e eu acredito!

O sol na pontinha do mar

abriu os olhos

e espraiou os seus raios

e traçou uma rota

Do fundo do mar

um crocodilo pensou buscar o seu destino

e veio por aquele rasgo de luz

Cansado, deixou-se estirar

no tempo

e suas crostas se transformaram

em cadeias de montanhas

onde as pessoas nasceram

e onde as pessoas morreram

- diz a lenda

e eu acredito!

é Timor!

Este poema é uma versão da lenda do crocodilo versificada, lenda já transcrita por Fernando Sylvan e que, agora, tem como título "Avô Crocodilo". Em sua estrutura formal, emana a tradição oral timorense em seus versos iniciais e finais, de quem conta uma estória: "diz a lenda/e eu acredito". Nos versos do poema, há também a personificação do sol, que desenha um novo 
caminho: "O sol na pontinha do mar/abriu os olhos/e espraiou os seus raios/e teceu a rota". Por fim, evoca a figura do crocodilo que, aos poucos, vai se transformando em "cadeias de montanhas", "onde as pessoas nasceram", "onde as pessoas morreram". No último verso, confirma, enfim, "é Timor", dando a finalização à lenda do crocodilo que se transforma em Timor.

Xanana, que escreveu no cativeiro, retrata sua própria estória, voltandose para a lenda do crocodilo. A lenda do crocodilo tipifica a estória do povo timorense e, à época do poema, simbolizava uma mensagem para a libertação desse povo.

Num outro período, em que o domínio já é da Indonésia e existe a busca da população de Timor e também de alguns grupos internacionais para que os fatos hediondos ocorridos no país cheguem à tona, surgem outros escritores, dentre eles João Aparício. A fase é posterior à década de 1970. Nesse período, o autor escreveu dois livros: Uma casa e duas vacas (2000) e À janela de Timor (1999); contudo, apenas o último foi distribuído e divulgado amplamente.

Publicado pela Editora Caminho, em 1999, no auge da ocupação indonésia em Timor, o livro À janela de Timor contém poesias que revelam uma melancolia nostálgica de textos escritos no território timorense, na Indonésia e em Portugal. Em sua obra, João Aparício retrata, em seu texto, o desejo de um Timor livre, relatando e delatando os acontecimentos por meio de seus poemas.

Seu primeiro livro teve o prefácio escrito por Sophia de Mello Breyner Andresen, que, analisando parte de seus poemas, assim o destaca:

Por isso hoje À janela de Timor é um livro de revolta moral e intelectual perante o esmagamento de um povo. De poema em poema o texto de João Aparício é a crónica dolorosa de um país ocupado e oprimido onde à sombra da bandeira vermelha e branca da Indonésia se sucedem os abusos, os insultos, os ultrajes e onde os direitos humanos são espezinhados e escarnecidos: mulheres violadas, homens na prisão, destruições, massacres. (APARíclO, 1998:14)

A obra destaca-se por conter poemas que divulgam a causa timorense e outros que, a partir de seu lirismo, retratam o amor e os sentimentos mais 
profundos arraigados na cultura da região, conforme as tradições e os ritos dos diversos povos que ocupam a região. Tal é o pensamento de Sophia de Mello Breyner Andresen, que assim coloca a questão:

E simultaneamente o povo timorense permanece aberto e atento à poética do país onde habita, desde a solenidade das altas montanhas, vivas de mitos, até à beleza da flor, das gentes humanas, da tradições antigas. É por isso que em À janela de Timor o poeta, apesar da violência e da dor, nunca perde a linha musical do encantamento. Assim, no livro de João Aparício estão igualmente presentes, lado a lado, os poemas da revolta e os poemas líricos. (APARÍCIO, 1998:15)

Neste trabalho, de Aparício, elencamos os poemas "Timor Forte", "Memórias a um herói desconhecido" e "O casamento e o rei das ilhas" para análise e comentários:

\section{Timor Forte}

Lahane - Díli, 10 de junho de 1985

Quando fores perpetuamente livre, Voa, Timor, voa! E mantém-te

Lá no firmamento, altura dos planetas.

Ergue fortaleza dos teus filhos,

Tece para as suas gerações uma ilha poderosa,

Para que nem por um só instante

Elas te digam, um dia:

Só nos legou uma casa,

Sem paredes, nem tecto,

Ó casa vazia!...

O poema Timor Forte, composto por dez versos, possui aliterações internas "quando fores perpetuamente livre", que destacam no verso o som do "r". Em seguida, "E mantém-te/Lá no firmamento, altura dos planetas", há o 
destaque do "t". O poema contém uma musicalidade que é acentuada gradualmente até o último verso: "Ó casa vazia!". Em sua primeira estrofe, há a proposição de um desejo, o de que Timor chegue ao seu destino, voar ao firmamento, para alcançar a liberdade perpétua. $\mathrm{O}$ eu lírico coloca Timor na mesma condição dos planetas, em tal esfera de grandeza.

Na segunda estrofe, portanto, acentua o desejo de liberdade, impondo as condições de liberdade: a fortaleza. É de se notar no seguinte verso: "Ergue fortaleza dos teus filhos", o sentido duplo dado à palavra fortaleza que distingue uma qualidade dos filhos de Timor e também denota o local onde os timorenses serão abrigados em segurança. Os verbos no imperativo indicam que o eu lírico conclama a Timor uma nova atitute para que haja mudança, a que vemos nos últimos versos:

\footnotetext{
Para que nem por um só instante

Elas te digam, um dia:

Só nos legou uma casa,

Sem paredes, nem tecto,

Ó casa vazia!...
}

No final, o eu lírico expressa a preocupação futura quanto às novas gerações, das quais será o legado da Pátria Timor, e que essas gerações possam sentir orgulho de seu país e nunca se arrependam por ter permanecido em sua terra. Timor, agora, é apresentado como "casa vazia", "sem paredes, sem tecto", pelo que afirma o eu lírico. Eis a representação do país em plena ocupação indonésia, quando algumas regiões se apresentam plenamente tomadas e despojadas de seus costumes e de sua cultura primeira, sem condições de exercer a sua soberania. 


\section{Memórias a um herói desconhecido}

A Manuel Atai, meu primo

Só depois que jazes no túmulo

É que és toda a nascente que não seca.

Só depois que jazes no túmulo

É que as aves cantam a canção

Da nossa aldeia.

Só depois que jazes no túmulo

É que melhor entendo a minha sede.

Oh irmão de Heróis e Heroínas, meu irmão!

Com tantos filhos de Timor

Vivem da tua nascente.

Em dez versos, agrupados em duas estrofes, o poema focaliza dois momentos ou duas situações. Na primeira, evoca a natureza em Timor e, na segunda, a situação presente de guerra e morte e seu significado para os timorenses. O eu lírico trata dos temas dos filhos que tombaram durante a guerra entre Timor e Indonésia, dedicando o texto a Manuel Ataí, ou Manuelito, que foi covardemente assassinado, em sua própria casa, com outros militantes timorenses, quando seu pai pensava que ele já estivesse a salvo.

A metáfora "és toda nascente" indica a gênese do herói que morreu em favor da Pátria e continua vivendo nos corações dos que sobrevivem. A nascente simboliza o crescente desejo de libertação de Timor.

Com o refrão "Só depois que jazes no túmulo", o autor reflete a questão geral e a particular que assola todo o povo timorense, com os conflitos gerados pela invasão. O perigo real é assimilado após a morte efetiva e a dor da perda de um "herói desconhecido", que pode ser sentida por todo o povo, pois é uma perda de todos. A morte faz com que o herói se torne parte da paisagem e da história timorense, conforme os versos do poema: 
Só depois que jazes no túmulo

É que as aves cantam a canção

Da nossa aldeia.

O entendimento real, o despertar, ocorre além da morte do herói, que, denominado "irmão", representa toda a luta timorense e desperta também o sentimento de identificação para aqueles que ainda vivem a luta, correndo o perigo de também morrer. Enfatiza, assim, o eu lírico, que, através da morte, a paz pode chegar e dar vida aos timorenses que permanecem "com tantos filhos de Timor/Vivem da tua nascente".

\section{O casamento e o rei das ilhas}

Na minha aldeia, após o casamento,

O violino de Abril Métan ${ }^{36}$ fazia-se ouvir,

E o perfume dos noivos e a doçura dos seus sorrisos,

Maior inveja ao rei da ilhas causaram,

Que inquieta punha a alma dos noivos!

O sol vermelho e lourejante

Que o manto de arrozais de Lequidiga,

Danahae, Uatulari e Maliana ${ }^{37}$ envolvia,

O encanto perdera, poema de criação enlutada.

Veloz como o relâmpago,

Lançou-se o rei sobre os noivos;

A gentil noiva despojou, com falsas razões,

Para dela filhos da sua raça gerar.

Assim castrou o noivo

E violou a noiva...

P'las traseiras o noivo atirando.

\footnotetext{
${ }^{36}$ Abril Métan, famoso violinista e compositor timorense, que morreu na década de 1990.

${ }^{37}$ Regiões de Timor-Leste, onde se cultiva arroz, uma das principais culturas agrícolas do povo timorense.
} 
Na pocilga, é lá que ele mora, lá!

Lá seu mortal corpo vive sonhando

A sombra da sua amável noiva,

Sem viver com a real.

Hoje, os gritos da noiva, violada e humilhada,

Uma voz, forte e clamorosa,

Sem ninguém que a oiça e chore...

As dores estranhas do noivo, castrado e torturado,

A sensação, insuportável e divina,

Sem ninguém que as alivie e importe...

Ai dos noivos! Já não são sinónimo

Do grande substantivo Amor...

Sem futuro e sem nobre lar...

Que relatos poderei eu ter melhores,

Para que seja também vosso

Este doloroso drama, ó mundo?

Vós, ó mundo, sabeis bem o que escrevo!

O título "O casamento e o rei das ilhas" já participa ao leitor o papel exercido pelo rei das ilhas (autoridade máxima no território) num dos eventos mais importantes da vida de um timorense: o casamento. Na primeira estrofe, por meio da construção das palavras "perfume dos noivos e a doçura dos seus sorrisos", o autor enfatiza a felicidade dos noivos durante o evento e também o prenúncio dos futuros acontecimentos: "inquieta punha a alma dos noivos". Na segunda estrofe, ocorre a metamorfose dos adjetivos: "o sol vermelho e lourejante" em contraposição a "poema de criação enlutada", pois "o encanto perdera".

A transição entre cores vermelho lourejante para enlutada, que denota cor escura, já anuncia a violência a ser imposta pelo rei das ilhas. O verbo que 
está no passado vai para o presente após a violência efetuada: "seu corpo mortal vive sonhando". E, finalmente, o verbo passa para o futuro, ao refletir sobre o que acontecerá após essa violência: "que relatos poderei eu ter melhores". O poema, composto em rimas mistas, não se enquadra numa estética determinada, por ser um poema contemporâneo.

Neste poema, João Aparício faz alusão às atrocidades ocorridas no então recente ano de 1991. Ao mesmo tempo, em tom de desabafo, quer transmitir ao mundo, através da metáfora do "noivo" castrado, o estigma vivenciado pelo povo timorense, que, desarmado, foi brutalmente atacado pelo inimigo indonésio, sem ter como se defender. Ao povo timorense, portanto, a virilidade lhe foi tirada, pelo desarmamento, para que não tivesse a faculdade de, pelo menos, poder, com suas armas, resistir aos ataques efetuados pelo inimigo. Desta forma, a noiva violada, terra "fértil" de Timor, fora destruída, ao ser invadida pelo inimigo, representando tal violação a ocupação sem resistência, sofrida ao ser tomada a nação inteira pelas tropas indonésias, sem que seus filhos timorenses tivessem tido tempo de se regozijar com a independência proclamada.

Sem dúvida alguma, a poesia de Timor e a poesia timorense escritas em língua portuguesa merecem destaque e análise, ao longo dos anos, porquanto estão ligadas à história de Timor-Leste.

Os referidos textos serviram para propagar a imagem de Timor, suas paisagens, e, ainda, denunciar os abusos ocorridos desde a época colonial portuguesa até, posteriormente, a ocupação indonésia.

A densidade passional e lírica dos textos encontrados são prova de que a força estética dos poemas foi tão intensa quanto o conteúdo ora lúdico e gracioso, ora realista e trágico que abordaram. 


\section{CAPÍTULO 3}

\section{Da prosa}

E se a palavra em si própria se forma vida e beleza, então contorna o seio intenso do tempo e exprime o que é e o que não é mas nos transcende: a magnífica voz do futuro.

José Craveirinha

Aquela espécie de esperança, feroz, determinada, à revelia do mais elementar bom senso, parecia-me uma doença. Ele, porém, defendia as suas posições com a paciente gentileza de um príncipe oriental...

José Eduardo Agualusa 


\title{
3.1 Considerações sobre a prosa do Timor
}

Ao contrário da poesia timorense, que surge no próprio território, a prosa timorense conhecida até o presente momento tem sido escrita na diáspora. Entretanto, ainda que não estivessem no campo de batalha, a luta travada pelos que estão na diáspora é também uma luta difícil. Ao ter que viver em um país que não é o seu, há a necessidade de fazer valer seu esforço longe de seus irmãos, há a necessidade de sobrevivência, há a saudade e, sobretudo, a dúvida e a dor, por não saber, de fato, o que acontece em seu país.

Sem dúvida, sobre a diáspora e as condições do intelectual que vive dessa forma, Stuart Hall, em seu livro Da Diáspora, afirma:

\begin{abstract}
Alguns indivíduos permanecem profundamente comprometidos com as práticas e valores "tradicionais" (embora raramente sem uma modulação diaspórica). Para outros, as chamadas identificações tradicionais têm sido intensificadas (por exemplo, pela hostilidade da comunidade hospedeira, pelo racismo ou pelas mudanças nas condições de vida mundiais, tais como a maior proeminência do Islã). Para outros ainda, a hibridização está muito avançada - mas quase nunca num sentido assimilacionista. Esse é um quadro radicalmente deslocado e mais complexo da cultura e da comunidade do que aqueles inscritos na literatura sociológica ou antropológica convencional. O "hibridismo" marca o lugar dessa incomensurabilidade. Em condições diaspóricas, as pessoas geralmente são obrigadas a adotar posições de identificação deslocadas, múltiplas e hifenizadas. (HALL, 2009:72)
\end{abstract}

Se, para uma poesia engajada, de denúncia, bastava ser timorense para ser bem compreendido por seus leitores mais próximos, para a prosa escrita na diáspora, também instrumento de informação e denúncia - visto que a questão timorense, como passou a ser chamada, deveria ainda continuar a ser difundida -, era também necessário tratar de algum modo da cultura dos vários povos em Timor, sem deixar de estabelecer seu vínculo com todo o processo colonial.

A prosa timorense desse momento, representada por poucos autores, será contemplada neste trabalho com alguns textos de Ponte Pedrinha, Luís Cardoso e também uma breve citação da obra de Domingos de Sousa. Dessa 
forma, será possível verificar algumas características presentes nos textos e, principalmente, analisar temas, tais como: diáspora, travessias e deslocamentos.

O conjunto da obra dos escritores timorenses conhecidos até então e que escreveram na diáspora teve como cenário guerras e revoluções para descrever a história do povo de Timor e suas tradições, envolvendo todo tipo de deslocamento de populações e indivíduos. Sobre travessias, deslocamentos, desterritorialização e diáspora, empregaremos respectivamente os preceitos dos professores Benjamin Abdala Junior, Rogério Haesbaert e Stuart Hall, respectivamente. 


\subsection{Luís Cardoso}

Luís Cardoso de Noronha nasceu em Cailaco, Timor, em 1959. Seu pai era um enfermeiro do ramo calade, que falava mambai, e sua mãe, que também era do ramo calade, falava o $\operatorname{laclo}^{38}$. Seu pai viajava muito, pois sua profissão exigia que visitasse doentes e, às vezes, ele levava toda a família. Assim, Luís Cardoso conviveu em Timor com vários grupos étnicos e se habituou aos mais diversos costumes. Mais tarde, estudou no seminário em Sobaida, em Díli, destinado aos filhos dos timorenses que trabalhavam para o governo e aos filhos dos portugueses que viviam em Timor. Na década de 1970, durante a invasão indonésia, Luís Cardoso foi para Lisboa, onde estudou primeiramente Medicina e concluiu o curso de Silvicultura no Instituto Nacional de Agronomia. Ainda em Lisboa, fez pós-graduação em Direito e meio ambiente. Foi professor de Matemática e tétum, enveredou pela diplomacia, auxiliando a militância timorense, mesmo estando na diáspora. Exerceu o cargo de representante do Conselho Nacional da Resistência Maubere.

A escrita timorense de Luís Cardoso, até o presente momento, enquadra-se por excelência nos moldes da literatura engajada, porquanto 0 autor refere-se aos temas pós-colonialistas em seus escritos e faz uma crítica ao colonialismo português que submeteu o seu povo até meados dos anos 1970.

Ao contrário de alguns países para os quais o romance e a prosa testemunharam o primeiro movimento literário propriamente nacionalista, em Timor, quase toda a escrita em prosa foi composta, até agora, na diáspora. Isso leva à seguinte questão: para quem escrevem os timorenses na atualidade? Assim como a poesia timorense lida entre os membros da militância, provavelmente com o intuito de transpor as fronteiras do país, como um grito de natureza delatora, tendo em vista os crimes ocorridos no país durante a época de sua escrita, sob a repressão indonésia, também a prosa,

\footnotetext{
${ }^{38}$ Mambai e lacló são línguas faladas em Timor. Com a diversidade linguística em Timor, para a conversação, foi adotada uma língua comum, no caso, o tétum. Luís Cardoso, portanto, foi alfabetizado em tétum.
} 
em certa medida, foi escrita como denúncia, expondo a situação política vivenciada em Timor.

Sobre a diáspora e os movimentos migratórios, observamos as teorias de Rogério Haesbaert e Stuart Hall. O primeiro fala sobre o mito da desterritorialização, sobre os deslocamentos dos povos, e o segundo fala sobre o posicionamento e a construção da identidade dos povos na diáspora.

Sobre o mito da desterritorialização, introduzido por Deleuze e Guatari, Rogério Haesbaert (2007) esclarece que tal conceito está além da circunscrição geográfica, ou seja, abrange planos sócio-culturais. O processo migratório de Timor é contemplado por tal teoria, pois os que saem da ilha, além de vivenciarem a trajetória física, devem também se adaptar ao novo meio de vida sócio-cultural, devem realizar uma travessia pessoal. Em seu livro O mito da desterritorialização, Haesbaert declara:

Muitos sociólogos e antropólogos, que há várias décadas ignoravam e/ou criticavam leituras geográficas ou sobre a territorialidade humana, redescobrem a importância da dimensão espacial da sociedade - agora, porém, notadamente, a fim de diagnosticar a polêmica desterritorialização "moderna" - ou "pósmoderna" - do mundo. Como se aí, também, não houvesse sempre, conjugadas, a destruição e a produção de novos territórios, tanto aqueles mais abertos e flexiveis quanto aqueles mais fechados e segregadores. Esta "dimensão mais concreta" em que se desdobram os processos sociais poderia mesmo proporcionar, em períodos de crise como este, melhor percepção da real intensidade das mudanças. (HAESBAERT, 2007:27)

Em Crónica de uma travessia, Luís Cardoso apresenta a questão do deslocamento por parte dos timorenses, bem como trata a questão dos timorenses que vivem na diáspora. O livro fala sobre movimento de travessia dos vários povos de Timor, ainda que, para alguns desses, fosse necessário subir às montanhas para se livrar do inimigo. Esse movimento causou 0 enfraquecimento geral da Nação, com a dispersão dos povos ali existentes e, em contrapartida, serviu para consolidar o modo de vida e as tradições dos sobreviventes.

Outro movimento que ocorreu no local foi o da corrente migratória dos jovens, que, por alguma motivação, partiram para Portugal. Estes foram vistos 
por seus pares como a parte da população de posição privilegiada, pois, para aqueles que compunham a elite timorense, mandar um filho para Portugal, a exemplo do que ocorrera em Angola, servia como garantia para que esse filho se salvasse dos conflitos ali presentes, ou voltasse a Timor com posição econômica melhorada. A referida travessia, contudo, não deixou de ser questionada, sobretudo pelos críticos que primeiro tomaram contato com esses textos em prosa produzidos por timorenses na diáspora.

De fato, todos aqueles que escreveram e escrevem sobre Timor, tendo nascido em terras timorenses ou não, têm algum contato político de caráter libertário com seu povo, visto que em nenhum momento foi deixada a memória de onde haviam partido, nem a solidariedade com aqueles que, tendo sido deixados no país, lutavam e morriam. Dessa forma, eivados de compaixão, preocupação e dor, os textos da diáspora foram se tornando a voz daqueles oprimidos que restavam em luta contra o inimigo indonésio após a descolonização e a invasão indonésia.

Sem dúvida, também é necessário ressaltar nesses textos que, como instrumento de denúncia, eles evidenciam as muitas falhas e os desmandos na época da colonização portuguesa. Parodiando Luís Cardoso, o tratamento dispensado às elites e aos menos privilegiados em Timor denunciava de forma gritante o poderio e a intolerância de um colonizador concomitantemente autoritário e displicente.

A queixa corriqueira que se faz, com base em farta documentação, consiste na denúncia dolorosa daqueles que sofreram as invasões e sempre foi voltada aos portugueses que, quer por promessas vãs, quer por tratados mal definidos, deixaram de resguardar as fronteiras timorenses contra os indonésios, quando o território ainda estava em seu poder.

Luís Cardoso iniciou sua carreira literária com a publicação do livro Crónica de uma travessia - A época do Ai-Dik-Funam, lançado em Portugal pela Editora Colibri em 1997. Além do talento para a escrita, Cardoso contou com o incentivo de seu primeiro leitor: o escritor angolano José Eduardo Agualusa, que o inseriu no mercado editorial. O timorense e o angolano foram colegas no Instituto Superior de Agronomia, em Lisboa, no início dos anos 1990. 
Crónica de uma travessia - A época do Ai-Dik-Funam é uma obra autobiográfica em onze capítulos que narra, em primeira pessoa, a estória de um timorense e de seu pai. O livro conta a travessia externa e interna das personagens, que, através dos vários episódios, abordam os costumes dos timorenses, a educação propiciada pelos portugueses e o desencanto ao desembarcar em Portugal que, para eles, seria uma espécie de "terra prometida".

Ao contar a infância, o protagonista vislumbra os acontecimentos da fase colonial portuguesa no território, denunciando o sistema colonial, o tratamento diferenciado concedido aos filhos dos portugueses e aos filhos dos timorenses na escola, a compra da benevolência por parte daqueles timorenses que detinham cargos e trabalhavam para a Administração portuguesa e o que se sucedia enquanto perdurava tal situação.

Embora já fosse o tempo da dominação indonésia, no início, a infância é retratada à luz dos fatos históricos e também são tratados alguns fatos da vida do pai do menino, como relampejos de memória, a exemplo da invasão japonesa ao território timorense, quando Timor foi tomado e dominado pelo exército nipônico durante a Segunda Guerra Mundial. Tais acontecimentos descritos, mesclados de palavras em tétum, delineiam naquele momento o modo de vida de Timor, ao mesmo tempo em que o narrador fala sobre a sua trajetória particular, de sua vida social e pessoal.

Dessa maneira, há também, por vezes, a descrição da pátria portuguesa idealizada em Timor e a real, depois vista quando da chegada lá. A Terra Prometida, que, por fé, timorenses pensavam que encontrariam, não passava de um local que mais recolhia que acolhia aqueles que necessitavam de refúgio, no limiar da desocupação portuguesa e da ocupação indonésia.

À guisa de formação acadêmica, muitos timorenses se dirigiam à metrópole portuguesa, provenientes, em sua maioria, de uma elite caracterizada por já ter tido a oportunidade de estudar o português em Timor, frequentando os seminários nos quais estudavam filhos das autoridades portuguesas que chegavam ao país. Assim, ao narrar a vivência no exterior, numa pátria que fora conhecida como encantada, o romance traz em seu bojo a narrativa da diáspora, pois o foco narrativo é o do protagonista já em 
Portugal, recordando suas vivências. Portanto, o olhar do narrador é um olhar de quem conhece o local em que nasceu, no entanto, um olhar distanciado, de quem vive na diáspora.

No decorrer do livro, fatos históricos vivenciados em Timor são destacados, tais como a Revolta de Manufahi e a constituição partidária que se deu no país. Além dessas questões e, evidentemente, da questão da diáspora, notamos, no texto, a recorrência do tema da memória individual e da memória coletiva: a narrativa do autor, enquanto memória individual, e o relato do que ocorrera com seu pai em outros tempos, tratando de guerras e revoltas que, relacionadas ao pai do narrador, que "perde a memória", vão se enredando entre fatos e tradições da terra de origem, evocando, assim, a memória coletiva de um povo.

Vale aqui lembrar que, segundo o conceito de Maurice Halbwachs (2004), a memória individual estaria ligada à memória multidimencional, intimamente relacionada à história sócio-cultural da sociedade na qual o indivíduo está inserido; é, portanto, uma memória social e não pode, de modo algum, permanecer apartada da memória coletiva.

Assim, também a memória do protagonista traz sua historicidade, relacionada à diáspora. Além disso, ao falar sobre o pai, o personagemnarrador aponta a diferença entre os dois, pois seu pai era um membro da União Democrática Timorense (UDT) e fazia parte do grupo que aceitava a continuação do domínio português como uma transição para a futura independência de Timor. O narrador, por sua vez, apoiava a FRETILIN, que defendia a independência imediata.

Embora o romance seja totalmente escrito em língua portuguesa, é de se notar a presença de muitas palavras em tétum. O modo de vida do timorense é descrito também por meio de crenças e de alguns costumes citados no livro.

No trecho a seguir, o autor retrata como viviam os timorenses na diáspora e, ao mesmo tempo, como eram tratadas as pessoas oriundas das excolônias que iam para Portugal, para estudo ou trabalho: 
Alguém me bateu nas costas. Recusei-me a virar, pensando que fosse o outro a querer pedir-me novamente tabaco. Com tanta gente a passar, logo teria de ser eu o alvo escolhido. As minhas costas não estavam certamente encurvadas pelo peso da nicotina. Aliás o último maço tinha-o oferecido àquele vagabundo, livrando-me de ser na noite de pirilampo. Ele precisava mais do que eu. Uma outra estrela do firmamento ou simplesmente um semáforo ambulante acenando paragens a essa correria louca encenada na fúria devastadora dos dias em busca de nada. Mas desta vez as mãos estavam mesmo pousadas sobre o meu ombro, pesadas e tinham o cheiro da humidade e do tabaco de Balibó. Virei-me. Eram uns olhos parecidos com os das enguias que eu supunha habitarem o lodo do rio. Assustei-me. Por momentos pensei que fossem a transfiguração desses entes submarinos.

- Chamo-me Domingos! - sossegou-me. - Este é o Mali Mau! indicou-me com o olhar o parceiro. - Viemos agora da Trafaria, onde trabalhamos nas obras, e vamos para Odivelas. - Vamos ali ao café. Pegou-me pelo braço direito arrastando-me por entre a multidão que corria em direção ao cais, onde o nevoeiro e o fumo espalhado pelo vendedor de castanhas escondia o barco, e as pessoas desapareciam como se se tivessem atirado ao rio. (CARDOSO, 1997:120)

De forma irônica, o autor descreve a sociedade portuguesa, que julga ocidentalizada, essa sociedade que vive em "correria louca encenada na fúria devastadora dos dias em busca do nada". É a descrição de uma típica metrópole em oposição ao campo, ou mesmo a capital, Díli, em Timor. Elucida também como era feita a exploração do timorense que ia para Portugal em busca de trabalho. De fato, entre os provenientes das diversas colônias portuguesas que chegavam ao país, alguns iam para estudar e, em outros casos, iam para trabalhar, quase sempre em trabalho braçal.

Adiante, surge a crítica ao sistema político já arraigado em Timor, que, à época, ainda não era um país independente. Na busca pela construção da identidade, a conversão ao cristianismo ou a aceitação dos costumes europeus por parte de alguns timorenses era, sem dúvida alguma, o que ocorria apenas a membros da elite, pois a grande parte da população preservava e cultivava seu próprio modo de vida e suas tradições. Para o narrador, portanto, causa estranheza encontrar Domingos e Mali Mau em Portugal, posto que eles não se enquadravam nos moldes daqueles que costumavam viajar à metrópole, os filhos de famílias pertencentes à elite de Timor ou os timorenses batizados que eram agraciados pelo clero: 
A FRETILIN querendo justificar a sua imagem de movimento libertador e regenerador dos valores ancestrais ergueu como bandeira um símbolo destituído das suas máculas colonial e cristã, restituído à sua primeira condição de nativo e gentio e que doravante passaria a ser o rosto do homem novo: o maubere. A UDT achava que conotar tal povo com essa expressão significava retirar-lhe a dignidade e não achava justo que se pudesse arvorar como símbolo uma palavra que ela própria utilizava para rebaixar quem não tinha instrução. Diziam que era como se tivessem ido recuperar um homem novo de uma casta antiga roubando a teoria de Rosseau, o bom selvagem. Mas todos sabiam que essa palavra tornada mítica ou ofensiva pelas formações partidárias adversas tinha um passado e um perfil. Domingos e Mali Mau personificavam o tal maubere, excluído das benesses do colonialismo português, rosto de velho num corpo de criança, descalço e analfabeto. Nunca teve acesso à instrução, não leu os manuais escolares, não sabia onde ficava Portugal, nem a língua falada, e uma grande parte, apesar do esforço ciclópico dos missionários, não tinha sido baptizada e mergulhava ainda nos cultos gentílicos. Eu me perguntava qual a razão por que vieram a Portugal. Se não teriam, de facto, feito uma opção errada e que fariam eles nesta terra sem um conhecimento prévio das coisas e dos lugares. (CARDOSO, 1997:122)

Pelo texto, é evidente a posição do narrador, que, tendo recebido instrução formal em Timor antes de ir para Portugal, possui um olhar mais crítico em relação ao processo colonial. Assim, questiona o sistema imposto pela colonização portuguesa, que privilegiou apenas os que moravam na capital, Díli, uma vez que a cristianização e o ensino da língua portuguesa não se deram de maneira tão acentuada nas outras regiões em Timor. A presença de Domingos e Mali Mau em Portugal deixava clara a situação dos timorenses que viviam fora da capital. E acentua a questão, ao tratar do uso da palavra maubere, que, conforme a época, foi apresentando significado diferenciado ${ }^{39}$.

- Domingos pagou o chá e agarrou-me pelo braço, agarroume pelo braço, arrastando-me até à paragem do autocarro.

- Vamos para Odivelas - ordenou.

Ainda eu não tinha dado a minha resposta já estava dentro do primeiro autocarro que estacionara na paragem. Com um destino à mercê da chuva. À medida que o autocarro atravessava a cidade,

\footnotetext{
39 "Maubere é uma designação que adotou o significado: "povinho pobre sem recursos, simples, sem condições". Era uma expressão usada na colonização para definir classes de pessoas. Depois da invasão, a FRETILIN pegou esse termo e o transformou em bandeira de luta, dizendo que seria por esses mauberes que iria lutar, que seria por esses mauberes, esse povo simples, pobre e desassistido que seria feita a revolução." (Sousa apud SAKAMOTO, 2002:110)
} 
via-Ihes os rostos calmos, encontrados à vidraça salpicada de gotas, e os olhos brilhantes direccionados para o exterior em busca de referências exactas percorridas anteriormente. Os passageiros foram abandonando os seus lugares ao longo das paragens intermediárias e o frio que entrava pelas portas eriçava-me os pêlos como se alguém invisível tivesse entrado pela janela para ocupar os assentos vagos. Quando ficamos apenas os três a olhar uns para os outros, para o motorista e para o descampado, pela primeira vez vi-lhes os olhos transtornados.

- É a última paragem - disse o motorista, desligando as luzes. - Façam o favor de sair.

Era uma charneca e ficava lá para os lados da Portela. Tínhamos apanhado o primeiro autocarro, fugindo da chuva sem saber para onde nos levava. Como que empurrados por algum espírito sobrenatural que nos quisesse armar uma partida, fomos parar a um local desconhecido, e o motorista, um fantasma, que na hora de ponta tivesse substituído o verdadeiro, aproveitando-se da calamidade do trânsito e do temporal.

- Não é Odivelas! - sussurrou Domingos.

- Rain-fila! - disse Mali Mau olhando para o descampado e depois para o firmamento em busca de uma estrela orientadora. $E$ sem falar conosco, descalçou as botas, despiu a roupa e ficou completamente nu. Depois voltou a vestir tudo de novo, mas às avessas, tal como a natureza, como forma de encontrar o caminho de retorno. (CARDOSO, 1997:125)

O trecho acima, além de retratar a reação dos timorenses diante de um local desconhecido, acentua também as diferenças entre o timorense da cidade e aquele que vivia no mato, diante do inesperado que ocorre numa terra distante. O narrador, timorense que foi para Lisboa estudar, percebe os rostos de seus conterrâneos aos poucos se transformando diante de um erro, pelo medo do desconhecido, e também pela vergonha de serem apanhados em situação embaraçosa numa terra estranha. Em tal situação, cabe a volta às origens, o que fica claramente demonstrado na reação de Mali Mau, ao exclamar "rain fila" (quando percebe que zombaram dele) e começar a se despir, conforme costume maubere, em situações semelhantes. É a situação daquele que se encontra na diáspora; vive num lugar, mas preserva seus costumes de origem.

A crítica de Claudiany Pereira, na síntese do livro Crónica de uma travessia - a época do Ai-dik-funam, coloca a situação de Timor frente ao cenário internacional. Ao situar Timor dentro do contexto mundial, com base nas várias invasões ocorridas na região, descreve o território timorense como local negligenciado até pelos próprios dominadores: 
Sobretudo, nas imagens de nação aqui expressas, fica clara a noção de que Timor, por mais reivindicado que tenha sido por várias facções presentes na narrativa: Japão, Austrália, Portugal, Indonésia, sempre foi território de ninguém, pois quando era potência de Portugal foi abandonada ao descaso, quando os indonésios tomaram conta, destruíram seu patrimônio humano e cultural, agora que está nas mãos dos gestores nacionais, carece do recurso estrangeiro para costurar a história destroçada pelas colonizações. E as narrativas destes locais de cultura são parte do resgate dos patrimônios culturais, muitos dos quais só existem na memória desses narradores. (PEREIRA, 2005:10)

Olhos de Coruja, Olhos de Gato Bravo, publicado em 2001, é o segundo romance de Luís Cardoso. O romance narra a estória de amor entre Beatriz, que tem os olhos de coruja, pois nascera com os olhos grandes, e Luis, que tem os olhos verdes, tais quais os olhos de um gato bravo. No início do romance, são relatados o nascimento e os antecedentes da família de Beatriz. A notícia do futuro nascimento da protagonista gera certo desconforto familiar, principalmente por parte do pai da menina, um professor-catequista que já tem dois filhos gêmeos, Mateus e Matias. Esse pai, religioso, acredita que a possível chegada de uma filha mulher seria um fator de desestabilização familiar, isso porque uma mulher, ao nascer, carregaria as mesmas características da mãe de sua esposa, também chamada Beatriz, que era a senhora de Raitetuc, ou seja, uma feiticeira. Como acontece na literatura africana, nos escritos timorenses, a figura mais velha, a avó, representa a sabedoria. E, sabiamente, é essa avó que ofertará o presente de casamento a Beatriz, que será o instrumento usado para que Beatriz mate Luis por motivos políticos.

O livro aponta para os acontecimentos gerados quando da criação dos partidos políticos em Timor no período pós-colonial. Nesse contexto, existem as facções partidárias e as disputas entre elas. Paralelamente, os rituais e as tradições timorenses são retratados neste livro, que fala bem de perto sobre os costumes das montanhas em Timor, onde não há tanta interferência por parte de imigrantes e deportados. Momentos ritualísticos na vida timorense são retratados no livro, tais como os costumes do casamento, o batismo e 0 nascimento da protagonista, que é contado como um momento peculiar às 
mulheres. No momento do nascimento, o pai de Beatriz deixa a casa, fazendo com que estejam presentes apenas mulheres da protagonista, conforme descrito no livro:

Ausentou-se propositadamente no dia em que chegaram as parteiras de Raitetuc enviadas pela minha avó para ajudar a minha mãe na tarefa de me dar à luz. Apressou-se a vestir o fato escuro, trocou o chapéu colonial branco por outro de feltro preto, selou o cavalo com a sela de couro impregnada de moedas de prata, pegou no chicote feito de rabo de cavalo para enxotar moscas e almas penadas e se foi embora. Tinha de ir cumprir um ritual fúnebre pela morte de um afilhado numa aldeia distante. A pressa fê-lo esquecer-se do petromax pendurado no meio da sala por um fio de arame. Feito pouco tempo regressou para buscá-lo. Sem essa fonte de luz não conseguia penetrar no interior escuro dos moribundos em busca das almas. Embora as más línguas tivessem dito que o petromax servia mais para despertar os sobreviventes do jogo de cartas que velavam o morto pela noite dentro do que para iluminar a última travessia da alma do deitado depois de ter fechado os olhos em definitivo. As parteiras acenderam a lareira para iluminar a minha chegada no mesmo instante em que o velho catequista se foi embora com o petromax na mão para iluminar a partida do defunto afilhado. No momento do meu nascimento não estava presente nenhum homem em minha casa. Confirmando desta forma o papel que cabe a cada um no ciclo da vida. O nascimento tem a ver mais com as mulheres e a morte com os homens. (CARDOSO, 2001:14-15)

No período acima, há todo um simbolismo inerente à obra. $\mathrm{O}$ pai de Beatriz não quer vê-la em seu nascimento, momento reservado às mulheres, e sai para uma cerimônia fúnebre, quando troca o chape (coloca o chapéu preto). Volta para buscar o petromax, que havia esquecido, a fim de "alumiar" o caminho, inclusive o da alma, daquele que já partiu; para esse efeito, vai à cerimônia fúnebre. Ele sai da casa com o petromax, porém, Beatriz nasce com os olhos tão grandes, que, mais tarde, serão vendados.

Simbolicamente, Beatriz não poderia enxergar o que se passava ao redor, nem se dar conta das situações pelas quais Timor passava. Teria uma vida protegida e guiada. Seus olhos são vendados por seu padrinho, Padre Santa, e ela passa a ser educada e conduzida pela tia Matilde. Vai para Portugal em companhia da tia e, ao regressar a Díli, durante a viagem, via marítima, é abordada por Luis Albuquerque, da facção portuguesa, que a pede em casamento. No final do romance, após o casamento, Luís já sabe que vai 
morrer, pois é ameaçado politicamente no limiar da guerra civil. Beatriz, então sua esposa, usa um alfinete que ganhara de sua avó e mata o próprio marido, enquanto realizam sua primeira noite de amor.

Ora, no livro, o autor trata da questão do casamento entre famílias, que geralmente era acordado pelos pais. Antes de conhecer Luis, Beatriz estava prometida a seu primo Natalino, como sua mãe havia sido prometida a seu pai há alguns anos. Assim, Luis Cardoso introduz a questão referente aos casamentos e como eram os costumes em Timor.

Embora a senhora de Raitetuc, avó da protagonista, simbolize os ritos e as tradições em Timor, principalmente os cultos referentes a crenças animistas, a noção do imaginário cristão, em Luís Cardoso, no que se refere à conduta das mulheres, está explícita em todos os romances e também em Olhos de Coruja, olhos de gato bravo. Fica bem clara essa noção, ao retratarmos o professor-catequista e suas expectativas. Sobre o ofício de catequista, este precisava ser casado e sua esposa deveria apresentar determinada conduta, segundo narra o professor Artur Marcos:

Nenhum professor catequista poderia ir solteiro tomar conta de ou abrir uma escola de posto. Até porque "um professor é como uma vela na escuridão, todos notam o que faz". Ainda: "O Sr. VigárioGeral escolhia ou orientava a formação dos casais. Era ele que escolhia o casamento dos professores-catequistas seguindo algum tipo de critério (por exemplo: escolher para um homem nervoso uma mulher calma, para uma mulher nervosa um homem calmo)". E: "Quando os padres entendiam que era tempo apresentavam um rapaz a uma rapariga, ou vice-versa, e perguntavam aos jovens se se aceitavam. Caso as respostas fossem afirmativas, no dia seguinte, de madrugada, às 4 ou 5 horas da manhã, casavam-nos na igreja". (MARCOS, 1995:78)

O romance Olhos de coruja, olhos de gato bravo, narrado pela personagem feminina, também fala sobre a travessia, a travessia de Beatriz, de Portugal a Díli, e sua travessia pessoal, pois esta tipifica Timor, por estar de olhos vendados, até o período pós-colonial.

O terceiro romance do autor, A última morte do Coronel Santiago, aborda a questão da diáspora e dos retornados, apresentada nos textos de 
Lobo Antunes e tão bem discutido por Eduardo Lourenço em seu Labirinto da Saudade.

O livro conta a estória de Lucas Santiago, protagonista, que está no exílio e reluta em aceitar a situação de Timor. Ao se deparar com a antiga namorada, ele é confrontado por sua própria condição, ainda que, em seu inconsciente, não conheça mais seu próprio lugar. Ao viajar para Timor, negase, ao máximo, a visitar sua família, seus parentes. Nega o encontro com suas origens, com seu passado, mas também não deseja viver apenas como aquele que sai do local e não mais voltou. Para quem ficou, Lucas é visto como um retornado e, por consequência, o próprio Lucas não sabe mais qual é o seu lugar.

Em A última morte do Coronel Santiago, Lucas Santiago, personagem principal, vive o drama daqueles que saem da Pátria por vontade própria, tendo vergonha da terra de origem, sem ao menos querer pensar ou discutir os problemas inerentes a sua Pátria.

O protagonista sabe, porém, que, retornando, não será mais o Lucas da origem, não será mais visto como um filho legítimo de Timor, como aqueles que permaneceram e lutaram pelo país, enfrentando os horrores da guerra. Como o livro A geração da utopia, de Pepetela, em A última morte do Coronel Santiago temos um retrato das incertezas acerca dos projetos de futuros e um balanço cruel do presente, da condição real de quem luta pela pátria fora dela, como vemos a seguir:

Chegou o ultimato de Maubisse. Ou ele subia desta vez ou nunca mais o fazia. Não compreendiam a demora dele. Esperavam que ele o fizesse desde o primeiro dia depois da sua chegada. Tinham reservado um grande cabrito preto criado nos altares do monte Manumera para a recepção familiar. Foi-se demorando em Díli mais por falta de encontrar uma idéia que pudesse abrir finalmente um caminho sobre o que deveria escrever do que por falta de convencimento. Também seriam sempre mais uns dias de vida que concedia ao animal uma vez que estavam determinados em sacrificálo. A sua intuição dizia-lhe que o convite, embora fosse para rever os parentes depois de estar tanto tempo ausente, tinha outros contornos que não the foram revelados. Sabia mais ou menos o que esperavam dele. Nada que não fosse previsto. Nada que não tivesse passado pela cabeça do coronel Pedro Santiago.

Nunca o disse em público nem deu mostras desse seu carácter. 0 medo apavorava-o. Sobretudo do que não conhecia. Da noite escura 
para lá das sombras onde poderia aparecer alguém que nunca lhe viu o rosto. Dos mortos e dos vivos, também dos fantasmas que não sabia bem se eram mais vivos do que mortos. Confidenciou à prima Mariana que não tinha nenhuma vontade de subir às montanhas. Não era por receio das vertigens nem do enjoo pelas altitudes. Mas por tudo quanto ali aconteceu.

Lucas Santiago, que já não fazia parte do seu lugar, lutava contra as velhas lembranças e contra sua própria situação de "retornado". O retorno significava, portanto, a travessia física e, ao mesmo tempo, a travessia interna e subjetiva. O regresso contemplava um olhar para dentro da personagem, que significava um reconhecimento que Lucas Santiago não queria vivenciar. Em outro trecho do livro, no qual Lucas retorna às montanhas, seu local de origem, Luís Cardoso apresenta o drama sentimental da personagem:

Esperavam o regresso dele para fazer o resgate da memória do velho coronel. Não estava em condições psicológicas para enfrentar tudo que dele esperavam, nem estava pronto para aguentar com o impacto de ver o sítio onde o coronel Pedro Santiago viu a luz pela última vez. Tinha decidido não falar mais sobre o assunto depois de tudo o que aconteceu. Fez isso durante o tempo em que esteve ausente. Chegado de Lisboa receava levantar alguma celeuma entre outra gente que o poderia acusar e com razão que também tinham os seus mortos para chorar. Mortos pelos indonésios por causa de uma pátria deles e não de um morto que defendia uma outra pátria ausente e que durante anos a fio fora um subserviente funcionário de uma milícia armada e recebia em troca a proteção dos seus bens e o honorífico título de coronel de segunda linha. Embora toda a gente soubesse que nem tudo foi como se disse. Disse-se apenas o que era conveniente dizer para se ouvir e justificar o que para alguns foi necessário fazer. Ninguém falou em ajuste de contas com o passado. Faltava apenas fazer um ajuste de contas com as palavras. Lucas não sabia como fazê-lo sem a presença dos protagonistas. Pedro Santiago estava morto e do Pedro Raimundo ninguém lhe disse nada. Um silêncio bastante esclarecedor. Provavelmente também estaria morto. Ainda não tinham feito o esconjuro e o enterro do coronel foi mais uma vergonha do que uma cerimónia fúnebre. A ama Prudência e Mateus tiveram de esperar pela noite para ir buscar o corpo do Pedro Santiago. Acompanhava-os o cão preto. Tiveram de arrastar o corpo desfeito por entre os atalhos encharcados de lama e quando não tiveram mais forças atiraram-no pela encosta abaixo para esconder o corpo da ira mortuária de Pedro Raimundo e tiveram de enterrá-lo naquele sítio escuro. Só o filho poderia fazer o resgate do coronel. Devolvê-lo à claridade dos novos dias. Essa era a dívida que tinha de pagar. Não enriqueceu no estrangeiro. Escreveu dois livros que mal se vendiam. Estava sem nenhum dinheiro guardado como fez muita gente que sempre viveu em Timor. Sabiam o futuro frágil 
que os esperava. Houve quem se tivesse precavido. Abundavam nas casas objetos de ouro. Os bancos não davam garantias. Cada um safou-se como podia quando tudo estava a arder. A bolsa de Criação Literária dava-lhe para escrever sem se preocupar com as despesas. Não tinha casa, nem carro, nem mulher e filhos.

Ao apresentar o que seria esperado da personagem, o autor apresenta, no trecho abaixo, o que o futuro reservava para Lucas Santiago. Interessante notar que nunca fizera o esperado e parecia estar se rumo, conforme ocorria com os retornados:

Livre para fazer da sua vida o que bem entendesse. Pouca coisa para se preocupar a não ser o simples facto de querer saber o que the reservava o destino. Quando o futuro deixou de fazer parte dos seus sonhos.

Há mais de vinte e cinco anos que esperavam por ele.

Estava num novo país onde não se revia. Sentia-se um hóspede do presente e era um estranho em sua própria casa, depois de ter tentado esquecer que durante anos a fio um passado que o mantinha refém. Decidiu prescindir dos seus honorários como professor no colégio. Uma pequena vaidade que não foi muito bem entendida pelos seus colegas. Toda a gente estava ali em Timor para ganhar mais o seu do que o céu e ele prescindia dos seus honorários com o argumento de que gostava de dar aulas. Uma paixão que nunca ocultou. (CARDOSO, 2003:225)

De fato, Lucas se abrigava em Díli, local cosmopolita, uma verdadeira Babel, para fugir da realidade que encontraria em Maubisse, sua terra de origem. Para ele, o fato de não reencontrar sua terra, sua família e seu passado o resguardaria do encontro consigo próprio, de ver o que não queria aceitar: a realidade de Timor pós-colonial. Teria ele a culpa por ter saído de seu lugar? Lucas Santiago vive como um desterrado e não conhece mais seu próprio lugar. É um personagem marginal, pois não é português e vive em Portugal e, quando vai a Timor, também não se conhece em meio aos seus. Como escritor, busca um lugar ao sol.

No romance, aparece o texto inserido dentro do texto, pois Lucas é um escritor, e seus personagens são os do romance Olhos de coruja, olhos de gato bravo. Assim, Luís Cardoso prodigiosamente narra a busca de um escritor pela escrita perfeita. Usando o recurso do metatexto, vai enredando o leitor que acompanha a trajetória das personagens. 
Em 2010, Luís Cardoso publicou Requiem para o navegador solitário no Brasil pela Editora Língua Geral, livro que já havia sido publicado em Portugal pela Dom Quixote, em 2007, sendo sua quarta obra.

Nesse livro, Cardoso narra a estória de Catarina, jovem chinesa que, partindo em busca de seu príncipe encantado, chega ao porto de Díli com sua bagagem e, dentro dela, o livro do navegador solitário Alan Gerbault A La Porsuite Du Soleil. Catarina, filha de um chinês, residente na Batávia, fica noiva de um comerciante português, que é o capitão do porto de Díli, quando este firma sociedade com o pai de Catarina. Após firmarem contrato, o noivo parte para Timor e Catarina se prepara para o casamento. Entretanto, a sociedade comercial começa a entrar em decadência e o pai de Catarina, com o intuito de assegurar o capital investido, manda a filha a Díli em busca do noivo e também sócio.

Ao aportar em Díli, com um livro de Alain Gerbault nas mãos, Catarina pensa que ali encontrará seu príncipe encantado, mas percebe que caiu numa armadilha e acaba encontrando vários degredados, pessoas politicamente engajadas, que formavam a população de Timor Leste à época. Quando finalmente acha o noivo, que está devendo a seu pai, Catarina é tratada como uma cobradora ou inimiga. E, ao partir para Goa, o noivo a deixa grávida e com a Fazenda Sacromonte para ser reconstruída e administrada.

Partindo em busca da fazenda, ela reconhece o administrador Malisera, que, na verdade, tem a posse da fazenda e, assim como Catarina, quer trocar o nome do local, chamando-a Fazenda Boaventura. Marcelo ou Malisera, podem ser a mesma pessoa, um espião ou um refugiado da Revolta de Manufahi. Com a recuperação da fazenda, Catarina volta para onde está seu filho e é apresentada aos japoneses que querem plantar algodão, comerciantes da Sociedade Agrícola Pátria e Trabalho.

Mais tarde, com a captura de Marcelo ou Malisera, Catarina é tomada como espiã dos estrangeiros (holandeses e japoneses) e tenta recuperar seu filho, que fora raptado. Quando está iminente a invasão dos japoneses em Díli, durante a Segunda Guerra Mundial, Catarina encontra Alain Gerbault, autor do livro que trouxera de casa quando viajou para Díli. Alain Gerbault, o navegador, 
entra na vida de Catarina como um príncipe encantado, recebendo os cuidados da moça até o instante de sua morte.

O Réquiem de Luís Cardoso é narrado em primeira pessoa pela protagonista Catarina, uma chinesa que recebeu educação europeia, vivia na Batávia com os pais e é obrigada a enfrentar muitos perigos, quando vai a Díli encontrar seu príncipe encantado.

Ao longo de sua trajetória, Catarina relata a situação política instaurada após a Revolta de Manufahi, comandada por Dom Ventura, e ainda o limiar da invasão japonesa em Timor-Leste, durante a Segunda Guerra Mundial. Há também alusão aos japoneses que laboravam na Sociedade Agrícola Pátria e Trabalho, pois Catarina é insistentemente procurada por eles, que pretendiam plantar algodão nas terras da protagonista.

As diversas guerras e rebeliões são um tema recorrente na obra de Luís Cardoso. Como acontece em Requiem para o navegador solitário, as guerras e revoltas também serviram como pano de fundo para os romances anteriores de Luís Cardoso, a fim de retratar os fatos ocorridos com o povo timorense. Assim, são descritas em seus textos a Revolta Boaventura ou Revolta de Manufahi e a Segunda Guerra Mundial.

Nesse romance, há a personagem Lavadinho, um agente repressor, espécie de representante da Polícia Internacional e de Defesa do Estado (PIDE) criada por Salazar para reprimir aqueles que eram contrários ao seu governo. Lavadinho é uma autoridade no local: sabe tudo o que acontece e conhece todas as pessoas. Todos temem esse homem, que é livre para praticar suas atrocidades. Assim, em nome da ordem, ele manda julgar em praça pública, manda prender e manda matar. No entanto, Lavadinho sempre tem as mãos limpas, e todos comentam na cidade, quando algo ocorre sem deixar rastro: "Isso é coisa do Lavadinho".

Com a Segunda Grande Guerra e a invasão japonesa ao Timor, os grupos internos acabam travando combate. Estes são a Coluna Branca, comandada por Lavadinho, e a Coluna Negra, liderada pelo irmão de Catarina, que chega da Batávia para vingar a morte de seu pai. A Coluna Branca realiza, portanto, verdadeiros massacres. É durante um desses ataques que Catarina 
acaba perdendo o seu filho Diogo. Esse episódio que aparece no livro, ocorrido entre 30 de setembro e $1 \underline{\underline{0}}$ de outubro de 1942, ficou conhecido como 0 Massacre de Aileu.

O uso de diversos elementos narrativos confere aspecto crítico ao texto de Luís Cardoso, pois o romance acaba denunciando os acontecimentos da época durante o período entre guerras.

Uma das peculiaridades nos romances de Luís Cardoso é a presença da figura feminina. Retratadas com meiguice desde o início, em seus romances, as mulheres deixam transparecer, no entanto, a verve audaz e o sangue guerreiro que possuem.

Catarina, do Réquiem para o navegador solitário, foi entregue a um homem para que o pai pudesse firmar sociedade com ele, um forasteiro, um desconhecido. Quando a sociedade entra em crise, o pai manda Catarina a Díli para cobrar a dívida. Catarina, que tem apenas 17 anos, acaba sendo maltratada. Contudo, ao acordar viva numa cama de hospital, após sofrer agressões por parte do noivo, Catarina resolve mostrar ao pai e ao noivo que é capaz de sobreviver com dignidade. Quando é instada a cuidar da fazenda do noivo, promete a si mesma que vai reerguer a propriedade sozinha. Vira, portanto, a nona do capitão do porto de Díli. Para os homens da região, a nona era uma mulher que, se deixada por um, deveria ser de qualquer homem. No entanto, Catarina resolve ficar sozinha, inclusive se arrisca ao procurar o refugiado Malisera, perseguido pelas autoridades. Após encontrá-lo, perde sua tranquilidade, pois passa a ser alvo das autoridades.

Ao longo do romance, Catarina conhece outros homens e, sem que perceba, em função de sua astúcia, vê-se envolvida nas tramas políticas da cidade. Tenta manter a neutralidade, resguardar a família. No entanto, quando seu filho é capturado, já sabe que não é mais uma pessoa frágil. Nesse momento, conhece Alain Gerbault, que precisa de uma enfermeira. Este, muito gentil com Catarina, encontra-se moribundo e a protagonista, então, presta-Ihe todos os cuidados até o momento final.

Num pequeno trecho do romance, 0 autor narra 0 encontro entre Catarina e o navegador solitário e destaca o uso do tétum e do português em 
Timor. No texto, o autor ilustra a situação de um médico ao atender seus pacientes, que falam apenas o tétum e, também, a situação do estrangeiro que, ao chegar em Timor, deve aprender algumas palavras do idioma tétum, antes de aprender o português:

O pequeno barco a remos encostou-se ao casco do veleiro. Ele apareceu no convés e sorriu ao médico. Era um homem muito magro e delicado. O epíteto de fantasma dos mares servia-lhe que nem uma luva. Não esperava pela visita de uma estranha. Não se apresentou. Nem exigiu que eu fosse apresentada. Foi o médico quem teve a iniciativa de dizer que desta vez trouxera a Catarina.

- Muito prazer, Catarina disse num inglês perfeito. O único senão foi a sua pronúncia francesa. Dizia a minha tutora que os franceses falavam as outras línguas como se se expressassem em francês.

- Muito prazer, Sr. Alain Gerbault retribuí a saudação em francês com uma pronúncia sem mácula que o fez ficar a olhar para mim indagando onde o teria aprendido.

- A Catarina fala francês como se fosse uma parisiense Fiquei na dúvida se devia tomar aquilo como um elogio ou como uma ironia, talvez achasse que a minha resposta tinha sido puro exibicionismo. Uma rapariga petulante a fazer-se a um estrangeiro. Uma animadora de visitantes. No seu livro $A$ la porsuite du Soleil insurgia-se contra as autoridades coloniais francesas que faziam de tudo para mudar os hábitos e o modo de vida dos povos das pequenas ilhas do pacífico.

- Falo tétum como se fosse uma timorense

- Tétum?

- Se quer sobreviver aqui uma achega do médico que teve de aprender a dizer a palavra língua em tétum, para não estar sempre a deitá-la para fora quando queria ver a de um doente.

- Tenho de aprender algumas palavras.

- Bom dia, boa tarde, obrigado apressou-se o médico a fazer a sua graça, que the valera a alcunha de Dr. Hamnasa, que em língua tétum quer dizer Dr. Sorriso. Nunca perdia o seu bom humor, fosse em que circunstâncias fosse ou em que lugar estivesse, no hospital, em casa, na rua ou numa cerimônia pública, menos na igreja, onde nunca entrava, porque o padre poderia tomar as suas observações como ofensas a Deus Nosso Senhor.

- Mas isso é português corrigiu o navegador solitário pensando que o médico estivesse a brincar com a sua ignorância. Embora não falasse, a língua portuguesa não the era de todo estranha.

- São as primeiras palavras de tétum que se aprendem, quando ainda não se sabe nada de português. Quanto ao resto, deixo ao cuidado do seu anjo da guarda, que passará a cuidar de si enquanto estiver na nossa companhia. Ela vai-lhe ensinar muita coisa. Fique o tempo que quiser. Mas não se demore muito. Não tarda nada que...

- Que fique bom sorriu com o meu acrescento, Alain Gerbault. (CARDOSO, 2007:166-167) 
Após a morte do navegador, a própria Catarina prepara a cova para enterrar aquele que teria chegado mais perto de ser o seu príncipe encantado.

Questionando as relações de poder, o autor usa da personagem feminina Catarina, uma chinesa, como uma espécie de metonímia da relação histórica que existiu entre as duas colônias - Macau e Timor -, mostrando o forte vínculo dos timorenses com a cultura oriental. Ao realçar a força de uma personagem aparentemente delicada e frágil, também faz dela uma metáfora do povo timorense - já bastante miscigenado com outras comunidades orientais - que, tal qual Catarina, é aparentemente delicado e frágil, mas, nos momentos importantes de sua história, tem se mostrado forte e determinado.

Fisicamente, Catarina é descrita com uma mulher bonita, com os pés delicados. Mesmo querendo ser admirada por outras qualidades, são os pés que a fazem diferente. A força da personagem é realçada pelas enérgicas e duras atitudes que precisa tomar, sempre em contraposição à figura frágil que aparentemente é.

Réquiem para o navegador solitário pode ser considerado um conto de fadas às avessas, no qual a heroína, que recebera uma educação esmerada e europeia, acredita que um dia encontrará seu grande amor para alcançar a felicidade. No entanto, ao partir em busca de sua felicidade, depara-se com uma série de infortúnios e desgraças, numa terra estranha, onde se respira medo, violência e insegurança. A grande questão levantada sobre o território de Timor-Leste é a da autoridade. Na realidade, a quem estava submetido o território timorense?

Já $O$ ano em que Pigafetta completou a circum-navegação é o romance publicado por Luis Cardoso em 2013. Neste livro, o autor inova, pois a narração parte de uma sandália do pé esquerdo. No livro, são narradas várias estórias sobrepostas do povo timorense em meio a guerras e lutas. A estória de Catarina do Réquiem para o navegador solitário é retomada, no momento em que o autor elucida o que ocorreu com ela e com o filho no livro anterior. Sobre o romance $O$ ano em que Pigafetta completou a circum-navegação, escreve Isabel Moutinho: 
É este um romance luminoso, em que a história contemporânea de Timor-Leste se transforma e resplandece no transbordante prazer de contar histórias. Histórias todas elas pontuadas por movimentos de navios: o Arbiru, que desapareceu um belo dia, o Lusitania Expresso, que nunca pôde trazer o auxílio português, e a nau Vitória, que aportou em Timor e na qual viajava António Pigafetta, o cronista da primeira viagem de circum-navegação. $E$ todas elas são contadas e reinventadas pela voz da narradora, a sandália esquerda da Carolina, filha de um empresário e integracionista confesso. (Moutinho apud CARDOSO, 2013:quarta capa)

Os romances de Luís Cardoso têm tido boa aceitação junto ao público lusófono. No entanto, os timorenses desconhecem de maneira geral a obra de Luís Cardoso. Os livros do autor, todos publicados em Portugal, traduzidos para vários idiomas e também um deles publicado no Brasil, não chegaram ainda a território timorense. No momento, Timor vivencia, com os livros de seus próprios autores na diáspora, fenômeno semelhante, em maior proporção, ao que ocorria quando do surgimento da imprensa na região. 


\subsection{Outros autores: Ponte Pedrinha e Domingos de Sousa}

Ponte Pedrinha, natural de família luso-timorense, nasceu em Same, região das montanhas em Timor. Sua família abandonou Timor-Leste em 1975, na sequência da guerra civil, tendo-se refugiado primeiro na Austrália e depois em Portugal, onde o autor vive até hoje (GONÇALVES, 2004:1).

No romance Andanças de um timorense, o autor fala da dor do momento preciso em que Timor foi invadido pelos indonésios, fala dos rituais timorenses, do crescente catolicismo. Com prefácio de José Craveirinha, escritor moçambicano, o livro conta a estória de um homem, Samuel, que, nascido em Timor, é levado para Portugal para não perecer em sua própria terra.

Em seu texto, Ponte Pedrinha, ao contar a estória da família de Samuel, fala sobre os fatos que ocorreram antes do nascimento do protagonista, colocando o leitor a par da força dos rituais e das crenças dos timorenses. Em meio ao pendor religioso, narra a desobediência dos pais de Samuel, que não querendo cumprir a lei, quando se casam, atraem uma maldição para o suco. Segundo a lei, a noiva deveria se deitar com o tio do noivo dois ou três dias após o casamento, conforme o costume (ESPERANÇA, 2003:4). Como são amaldiçoados, é descrito por Henriqueta Gonçalves, em seu estudo, segundo narra o livro:

A história inicia-se com o difícil nascimento de Samuel Costa, aliás, Kíri-Rêti, a personagem central desta narrativa, filho de Kêti-Kia e Kotená. A parteira que vai ajudar o nascimento da criança, KumaLou, num momento de interioridade que o narrador deixa que o leitor conheça, introduz o leitor na importância dos espíritos dos antepassados para aquele povo e nalguns dos seus mitos:

"Sentindo as pernas fraquejar, Kuma-Lou apressou o passo. E no refluir dos pensamentos, amaldiçoou a insolência de Kotená e de Kêti- Kia.

Aquele pressentimento era para ela 0 mais grave e reiterado de todos, o que estivera velado durante todo o dia, como se aguardasse - crepúsculo para libertar a ira dos avós. Não conseguia compreender a soberba de jovem casal nem deixar de perguntar quem seria atingido pela morte. E quanto mais pensava e recordava, mais tenebrosas que pareciam as desgraças que o acto tresloucado de Kotená e Kêti-Kia tinha atraído sobre todo o suco. (...) Sentindo-se 
percorrida por uma vibração misteriosa, Kuma-Lou deixou cair o castanho dos olhos e procurou as pegadas dos avós como procurava a sua própria memória." (PEDRINHA, 1998:40)

"Erguendo o olhar para o céu, lançou-o depois para a mãe de KêtiKia:

- É preciso esconjurar os avós!

- Ouviste, Kêti-Kia? - inquiriu a mãe.

- É a única maneira de a criança nascer - explicou a parteira..

Perante a mudez de Kêti-Kia, a mãe continuou:

- Faz o que achares melhor, Kuma-Lou.

A parteira levou o tabaco em rama à boca e mastigou-o exactamente como fizera com a amêndoa do coco.

- Vamos! Inspira! Iha, barua - contou até cinco. - Não largues a corda! Expira! Se os avós escutarem a minha prece e condescenderem, irás sentir uma enorme vontade...

Dito isto, Kuma-Lou soprou a pasta de tabaco sobre o ventre de KêtiKia e massajou-o sete vezes. Depois, invocando os antepassados, orou:

- Upaun-perani, upaun-tamu,(avô paterno e avô materno, respectivamente) já estais nesta mãe. Não o impeçais agora de sair." (PEDRINHA, 1998:47)

Sobre o livro, Isabel Moutinho revela, em seu estudo crítico Despontar do romance em Timor-Leste:

O romance ganha força pelo tom de extraordinária sinceridade da voz narradora, infelizmente não escorada numa rigorosa técnica literária. $\mathrm{O}$ romance sublinha a importância do catolicismo, religião que apesar de estrangeira se tornou num rasgo definidor da identidade timorense. A insistência do narrador em que se lhe chame apenas 'um Timorense sem cidade' (7, 87, 88 etc.) aponta para um retrato colectivo do povo timorense. Pode-se, portanto, ler o romance como alegoria da cristianização de Timor. Graças ao trabalho dos missionários cristãos do século XVI (THOMAZ 1994:597-600) e à obrigação, no século $X X$, de escolher uma das cinco religiões reconhecidas no Pancasila indonésio (HICKS 2011:120), o catolicismo enraizou-se inabalavelmente no coração dos Timorenses. O trecho em que até o Mata-blolo (padre animista de Ataúro) aceita o baptismo católico (53) parece confirmar a justeza desta interpretação. Contudo, a partida do narrador para África como missionário e a sua desaparição numa guerra civil africana cria ambiguidades difíceis de destrinçar para o leitor. Haverá uma alusão à guerra civil que se preparava em Timor? Neste caso, seria mais fácil entender o sentido do romance se houvesse referências explícitas. $O$ aspecto mais positivo é afinal a descrição pormenorizada de rituais e práticas ancestrais de Timor-Leste, que 
permitem ao leitor entrar num mundo geralmente inacessível. (MOUTINHO, 2011:3)

No livro, o autor insere alguns poemas de cunho claramente religiosos, demonstrando, assim, a opção do personagem que, entre um casamento e a vida religiosa, decidiu dedicar sua vida às práticas divinas.

Domingos de Sousa, que atualmente reside no Brasil, escreveu os livros Colibere: um herói timorense (2007) e também Histórias da Resistência Timorense (2010).

Sobre o romance Colibere: um herói timorense, escreve a professora Isabel Moutinho:

Colibere começa nos últimos anos do colonialismo português, numa aldeia de Manatuto, com condições de vida deploráveis: miséria, 'atraso de séculos' (15), subordinação da mulher em situação de quase escravatura e uma visão fatalista do mundo (9) que impossibilita qualquer esperança. O romance inicia-se com os preparativos dum casamento combinado, à maneira timorense, com o devido barlaqui (16-17). O segundo capítulo é sobremaneira discursivo, com extensas citações de estudos sobre costumes timorenses. Apesar da fascinante aprendizagem cultural que proporciona, não deixa no entanto de se tornar pesado, pois pertenceria melhor à antropologia do que à ficção. Contudo, com o nascimento de Colibere, o filho do casal, o romance começa a seguir a vida da jovem família, adquirindo ritmo e mérito literário. (MOUTINHO, 2011:4).

Sem dúvida alguma, um romance singular, que apresenta a personagem vivenciando diretamente os sofrimentos causados pela invasão indonésia. Colibere perde o pai e é preso pelos soldados indonésios. Com isso, acaba perdendo a razão. Segundo Moutinho (2011), o texto é contundente, pois evoca momentos cruéis da ocupação indonésia e também retrata o momento da guerra civil, no qual houve o fratricídio por parte de duas facções políticas timorenses, leais a partidos adversários. 


\section{Considerações finais}

O percurso pelos textos literários de Timor aqui realizado e os estudos histórico-sócio-políticos que auxiliam em sua contextualização e entendimento são apenas uma primeira contribuição para a escrita da futura história da literatura timorense. Em vista da riqueza cultural e histórica de Timor-Leste, podemos vislumbrar a elaboração dos mais diversos estudos que possam se valer do presente trabalho.

Através dos textos literários, é possível conhecer a cultura, os aspectos sócio-culturais e também a história de um país. No caso de Timor-Leste, a literatura de língua portuguesa, ainda que de maneira incipiente, consegue mostrar o país em seus vários momentos históricos e em sua diversidade cultural.

A proposta deste trabalho foi apresentar alguns textos escritos por timorenses e sobre Timor-Leste, apresentando, inicialmente, tudo o que foi dito sobre a incipiente literatura de língua portuguesa deste país, contextualizando os textos e os autores tratados.

Tendo em consideração que a maior parte dos estudos mais aprofundados sobre o país versavam sobre Política, História, Antropologia e Linguística, julgamos que um trabalho mais detido sobre literatura vem contribuir para um conhecimento mais complexo daquela realidade, sobretudo para ajudar no entendimento da imagem que hoje temos de Timor-Leste na bibliografia de língua portuguesa.

Rememoramos, para melhor entendimento, o início da colonização na região e procuramos tratar da história do ensino de língua portuguesa naquela ilha, para que se fizesse luz sobre a questão da identidade nacional ligada à língua portuguesa em Timor. O porquê do ensino e da escolha da língua portuguesa como língua oficial em Timor tem sido questionado até os dias de hoje. Em nosso estudo, reiteramos, a par do que fora apresentado pelos professores Regina Helena Pires de Brito e 
Geoffrey Hull, a importância da preservação e da permanência do ensino do português para a memória e a identidade da Nação.

A pesquisa levou-nos à apresentação dos escritos de literatura de viagem e dos primeiros compêndios elaborados pelos missionários para o aprendizado do idioma. Em ambos os casos, ficava patente a precária introdução da língua portuguesa em Timor, além de evidenciar quanto aquela ilha demorou para ser alvo de um projeto de efetiva ocupação por parte dos missionários católicos e dos portugueses.

Em vista de a imprensa ter demorado muito para se instalar naquela ilha, a literatura de língua portuguesa só começou a se revelar de fato no início do século XX.

Essa viagem inicial se fez sentir pelos primeiros poetas portugueses que lá estiveram, Osório de Castro e Ruy Cinatti, que, pela grata experiência na região, resolveram descrever e escrever, a fim de apregoar o que viram e sentiram em relação à ilha. Os momentos políticos e históricos apresentados na época da escrita serviram para melhor elucidar e contextualizar os poemas dos autores portugueses.

Nesse momento, evidencia-se quanto Timor-Leste foi objeto daquilo que Edward W. Said designa por "orientalismo", isto é, um Oriente elaborado a partir dos interesses e do olhar do Ocidente. Ainda assim, vale notar que, ao menos Ruy Cinatti, ao aportar na ilha no pós-Segunda Guerra Mundial, pôde ver a ilha devastada e procurou se aproximar dos timorenses, produzindo uma obra com maior originalidade.

No decorrer do século XX, é possível constatar que se, por um lado, temos inicialmente um juiz português compondo poemas bucólicos sobre a região em meio a revoltas locais, logo em seguida temos um agrônomo, no pós-guerra, presenciando uma região arrasada, que necessitava da solidariedade da metrópole portuguesa para reverter tal situação. São imagens antagônicas que, no entanto, apontam para um mesmo princípio: o do descaso por parte dos administradores portugueses para com a população timorense. 
De maneira singular, os textos apresentados após a anexação da região pela Indonésia são escritos por timorenses autênticos e imbuídos de profunda sensibilidade e qualidade artística. É de se estranhar, contudo, que tais escritos tenham ficado durante tanto tempo obscurecidos, pois Timor passou a ser objeto de estudo de historiadores e cientistas sociais no intuito de explicar as atrocidades ali cometidas.

A literatura engajada desse período forma a parte mais consistente da literatura timorense, pois, a partir daí, temos as bases para uma literatura nacional que pode marcar sua peculiaridade e seu diálogo com as outras literaturas de língua portuguesa. O que marca, também, as bases do comunitarismo linguistico entre os países de língua portuguesa. A presença da base linguística - comunitária é notada diante dos versos dos poetas engajados que, nos vários níveis da luta de resistência contra a invasão indonésia, escreveram em tétum e em português para denunciar ao mundo as bárbaries cometidas em sua terra.

Houve, por sinal, à época da resistência contra o domínio da Indonésia, um movimento de solidariedade por parte dos países africanos de língua portuguesa, sobretudo Moçambique, que muito auxiliou Timor. Conforme aponta José Manuel Pureza, em obra organizada por Boaventura de Sousa Santos (2003), durante os duros anos de repressão indonésia, Moçambique e os outros países africanos do PALOP - países africanos de expressão oficial portuguesa - pugnaram junto a instituições intergovernamentais por um posicionamento e por medidas de ações efetivas para a cessação da crueldade exercida pelos indonésios em Timor.

Nessas redes de comunitarismo, surge a solidariedade que também aparece na literatura. Resta dizer que, dos livros publicados pelos autores timorenses, desde a coletânea Enterrem meu coração no Ramelau, até a prosa em Ponte Pedrinha, vários têm apresentação e prefácio escritos por escritores angolanos e moçambicanos. Como vimos, a coletânea de poemas Enterrem meu coração no Ramelau foi organizada e publicada pela União dos Escritores Angolanos. 
Brasil e Portugal não aderiram de imediato, porém, a essa política de solidariedade e comunitarismo. Apenas no período da reconstrução de Timor, quando a ONU tomou a frente da situação, após a desocupação indonésia, ambos empreenderam um movimento literário solidário aos timorenses.

A escritora portuguesa Joana Ruas publica, em 1981, o livro Corpo colonial (1981), romance que conta de maneira intimista os costumes dos portugueses para com suas próprias mulheres e as nonas, concubinas timorenses. Embora já houvesse sido escrito, na fase colonial, o livro Caiurú (1939), de Grácio Ribeiro, que versava sobre o mesmo tema, percebemos em Joana Ruas um olhar direcionado à crítica sensível em relação às mulheres timorenses. Joana Ruas publicaria ainda, em 2009, o livro Contos timorenses, sobre estórias de Timor.

No Brasil, com a direção dos professores Benjamin Abdala Junior, Maria Nery Garcez e Teresa Rita Lopes, é publicada, em 1999, o segundo número da Orion - Revista de poesia do mundo de língua portuguesa, com poemas de Xanana Gusmão, Eric Ponty, Teresa Rita Lopes e texto de Benjamin Abdala Júnior, versando sobre Timor.

A imagem literária que hoje temos de Timor-Leste também é, em grande parte, elaborada pela literatura que se constitui na diáspora. O romance timorense surge sobretudo nesse contexto, caracterizando-se por discutir os vínculos entre Timor e a antiga metrópole portuguesa, assim como discutindo os problemas implicados em uma independência política muito recente e os traumas deixados pela luta pela libertação do jugo indonésio.

Nos romances de Domingos de Sousa, Luís Cardoso e Ponte Pedrinha, está presente também a questão da memória individual e coletiva. A preservação dessa memória é necessária ao povo timorense, que hoje se vê na contingência de afirmar sua identidade em âmbito internacional, necessitando, para tanto, produzir a narrativa de seu passado e a projeção de seu futuro. 
Esperamos, portanto, com este trabalho, contribuir, ainda que muito pontualmente, para a elaboração dessa grande narrativa, fornecendo subsídios para que novos pesquisadores possam aprofundar e dar continuidade ao percurso geral que aqui traçamos. 


\section{Referências bibliográficas}

\section{Obras literárias}

AlBuqueRQuE, Pedro Miranda \& TERCIO, Ricardo. Timor. Dez dias sem horas dentro. Lisboa: Biblioteca por Timor, 2001.

APARícIO, João. À janela de Timor. Lisboa: Editorial Caminho, 1999.

BARBOSA, Duarte. Livro de Duarte Barbosa. Em que dá relação do que viu e ouviu no Oriente. Lisboa: Agência Geral das Colónia, 1946.

CARDOSO, Luís. Crónica de uma travessia - A época do ai-dik-funam. Lisboa: Publicações Dom Quixote, 1997.

. Olhos de Coruja Olhos de Gato Bravo. Lisboa: Publicações Dom Quixote, 2001.

A Última Morte do Coronel Santiago. Lisboa: Publicações Dom Quixote, 2003.

. Réquiem para o navegador solitário. Lisboa: Publicações Dom Quixote, 2007.

. O ano em que Pigafetta completou a circum-navegação. Porto: Sextante Editora, 2013.

CASTRO, Alberto Osório. Obra Poética, vol. I. Lisboa: Imprensa Nacional-Casa da Moeda, 2004.

CINATTI, Ruy. Paisagens timorenses com vultos. Lisboa: Relógio D’Água, 1996.

. Um cancioneiro para Timor. Lisboa: Editorial Presença, 1980.

GUSMÃO, Xanana. Mar meu. Poemas e pinturas. Porto: Granito Editores, 1998.

PEDRINHA, Ponte. Andanças de um timorense. Lisboa: Edições Colibri, 1998. 
RIBEIRO, Grácio. Caiúru (Romance Timor). Lisboa: Coleção Amanhã, 1939.

RUAS, Joana. Corpo Colonial. Coimbra: Ed. Centelha, 1981.

- A pedra e a folha/Crónicas Timorenses. Vila Nova Gaia: Calendário de Letras, 2009.

SYLVAN, Fernando. A voz fagueira de Oan Tímor (poesia). Lisboa: Edições Colibri, 1993.

UNIÃO DOS ESCRITORES ANGOLANOS. Enterrem meu coração no Ramelau. Coletânea. Luanda, 1982.

\section{Obras críticas e teóricas}

ABDALA JUNIOR, Benjamin; GARCEZ, Maria Nery; LOPES, Teresa Rita (Orgs.). Orion - Revista de poesia do mundo de língua portuguesa. Brasil/Portugal: 1999.

ABDALA JUNIOR, Benjamin. Literatura, História e Política: Literaturas de língua portuguesa no século XX. São Paulo: Ática, 1989.

. De vôos e ilhas: Literatura e Comunitarismos. São Paulo: Ateliê Editorial, 2003.

ADÃO, José Carlos. A formação da constituição de Timor-Leste. Dissertação de Mestrado. Universidade Católica Portuguesa, 2009.

ADORNO, Theodor W. Notas de literatura I. Tradução de Jorge M. B. de Almeida. São Paulo: Duas Cidades, Ed. 34, 2003.

ALMEIDA, Nuno Carlos H. Dissertarção de mestrado intitulada Língua portuguesa em Timor-Leste: ensino e cidadania, Universidade de Lisboa, 2008.

AMAL, Teresa. Sete mulheres de Timor Nain Hitu. Lisboa: Ação para Justiça e Paz, 2006. 
ANDERSON, Benedict. Comunidades imaginadas: reflexões sobre a origem e a difusão do nacionalismo. Tradução de Denise Bottman. São Paulo: Companhia das Letras, 2009.

ANTUNES, Jorge. O que é Timor? Língua e literatura em Timor-Leste. 2007.

BHABHA, Homi K. O local da cultura. Tradução de Miriam Ávila, Eliana Lourenço de Lima Reis e Gláucia Renate Gonçalves. Belo Horizonte: Editora UFMG, 2003.

BORDA d'AGUA, Flávio. Le Timor face à Seconde Guerre Mondiale (19411945). 2008.

BOSI, Alfredo. Dialética da colonização. São Paulo: Companhia das Letras, 1992.

BOURDIEU, Pierre. A economia das trocas simbólicas. Tradução de Sérgio Miceli, Silvia de Almeida Prado, Sonia Miceli e Wilson Campos Vieira. São Paulo: Editora Perspectiva, 2007.

. Os usos sociais da ciência: por uma sociologia clínica do campo científico. Tradução de Denise Barbara Catani. São Paulo: Editora Edusp, 1997.

BOXER, Charles. O império marítimo português, 1415 - 1825. Lisboa, Edições 70, 2005.

BRAGA, Paulo. A ilha dos homens nus. Lisboa: Editorial Cosmos, 1936.

BRETES, Maria da Graça. Timor: Entre invasores (1941-1945). Lisboa: Livros Horizonte, 1989.

BRITO, Regina Helena. Sensibilizando para a comunicação em língua portuguesa - uma experiência em Timor-Leste. São Paulo: Mackpesquisa, 2006.

- Temas para a compreensão do atual quadro linguístico de Timor-Leste. In: Ciências e Letras. Porto Alegre, 2010.

BURKE, Peter. Hibridismo cultural. Tradução de Leila Souza Mendes. São Leopoldo: Editora Unisinos, 2008. 
CANDIDO, Antonio. Literatura e Sociedade. São Paulo: Companhia Editora Nacional, 1965.

CASTRO, Alberto Osório de. A ilha verde e vermelha de Timor. Lisboa: Edições Cotovia, 1996.

CORREA, Armando Pinto. Gentio de Timor. Lisboa: Edição do autor, 1934.

COSTA, Luís. Borja da Costa. Seleção de poemas/Klibur Dadolin. Lisboa: Lidel, 2009.

CUCHE, Denys. A noção de cultura nas ciências sociais. Tradução de Viviane Ribeiro. Bauru: Edusc, 2002.

CUNHA, João M. Teles. Timor e o Comércio do Sândalo. In: Os espaços de um Império. Porto: Câmara Municipal do Porto, 1999.

FERREIRA, Miguel Vieira. O Cristo no Juri. São Paulo: Oficinas gráficas de Saraiva, 1957.

FIGUEIREDO, Fernando. Timor. História dos Portugueses no Extremo Oriente. Lisboa: Fundação Oriente, 2000.

GAGLIATO, Márcio. Timor Leste e a ocupação Indonésia: A religião como operador de resistência. Dissertação de Mestrado. São Paulo: Pontifícia Universidade Católica de São Paulo, 2008.

GARMES, Helder. Oriente, Engenho e Arte. São Paulo: Alameda Casa Editorial, 2004

GONÇALVES, Henriqueta Maria. Apresentação de Andanças de um Timorense de Ponte Pedrinha. In: Letras e Letras, $<w w w . i p n . p t /$ iteratura/letras/ensaios.htm> Acessado em janeiro de 2004.

HAESBAERT, Rogério. O mito da desterritorialização: do "fim dos territórios" à multiterritorialidade. Rio de Janeiro: Bertrand Brasil, 2007.

HALBWACHS, Maurice. A memória coletiva. São Paulo: Centauro Editora, 2004.

HALL, Stuart. Da Diáspora: identidades e mediações culturais. Tradução de Adelaine La Guardia Resende et al. Liv Sovik (Org.). Belo Horizonte: Ed. UFMG, 2003. 
A identidade cultural na pós-modernidade. Tradução de Tomaz

Tadeu da Silva e Guacira Lopes Louro. Rio de Janeiro: DP\&A Editora, 2006.

HULL, Geoffrey. Timor Lorosa'e. Timor Leste - Identidade, Língua e Política Educacional. Lisboa: Instituto Camões, 2001.

LOBATO, Manuel. Timor nos descobrimentos e na cartografia. In Coral ํㅡ 2, Lisboa, 1992.

. Timor, História dos portugueses no extremo Oriente, vol. I e II. Lisboa, Fundação Oriente, 2000.

LOUREIRO, Eduardo. Labirinto da saudade. Psicanálise mítica do destino português. Lisboa: Gradiva, 2007.

LUKÁCS, Georg. A teoria do romance. São Paulo: Duas Cidades, Editora 34, 2007.

MARCOS, Artur. Timor timorense com suas línguas, literaturas, lusofonia. Lisboa: Colibri, 1995.

MATOS, Artur Teodoro. Tradição e inovação na administração das ilhas de Solor e Timor: 1650-1750 (p.345 - 356). In: O humanismo latino e a cultura do Extremo Oriente. Treviso: Fundazione Cassamarca, 2005.

MARQUES, A. H. de Oliveira. História dos portugueses no Extremo Oriente, vol. I, tomo II. Lisboa: Fundação Oriente, 2000.

MARTIN, Vima Lia. Literatura e marginalidade: um estudo sobre João Antônio e Luandino Vieira. São Paulo: Alameda Casa Editorial, 2008.

MORE, Rodrigo F. Fundamentos das operações de paz das nações unidas e a questão de Timor-Leste. Dissertação de Mestrado - Faculdade de Direito da USP, São Paulo, 2002.

MOUTINHO, Isabel. Despontar do romance em Timor. In: http://www.tlstudies.org/pdfs/202011/chp_11.pdf. Acessado em fevereiro de 2012.

MUNANGA, Kabengele. A revolta dos colonizados. São Paulo, Editora Atual, 1995. 
OLIVEIRA, Luna de. Timor na história de Portugal, vol.l. Lisboa: Fundação Oriente, 2004.

PEREIRA, Claudiany. Luis Cardoso e a vivência da diáspora: nota sobre a literatura de Timor Leste.

http//:revistas.fw.uri.br/index.php/revistalinguaeliteratura/article/.../56/108 Acessado em dezembro de 2010.

PONTE, Carmo S. Oliveira Martins - A história como Tragédia. Lisboa, Imprensa Nacional - Casa da Moeda, 1998.

PUREZA, José Manuel. Quem salvou Timor Leste? Novas referências para o internacionalismo solidário. In: SANTOS, Boaventura de Sousa (Org.). Reconhecer para libertar: os caminhos do cosmopolitismo multicultural. Rio de Janeiro: Civilização Brasileira, 2003.

RICOEUR, Paul. Teoria da Interpretação. O discurso e o excesso de significação. Lisboa: Edições 70, 2009.

RONZANI, Ana Cláudia P. Elites timorenses em travessias: um olhar de Luís Cardoso. Trabalho de Conclusão de Curso de Graduação. Brasília: Universidade de Brasília, 2008.

SÁ, Artur Basílio. Textos em Teto da Literatura oral Timorense, vol. I. ㄲo 45 . Lisboa: Junta de Investigações do Ultramar, 1961.

SAKAMOTO, Leonardo M. A independência de Timor Leste: um estudo sobre as causas do sucesso da Resistência Timorense na luta contra a Indonésia. Dissertação de Mestrado, Faculdade de Filosofia, Ciências e Letras da Universidade de São Paulo, São Paulo, 2002.

SANTA, Jose Duarte. Australianos e japoneses na II Guerra Mundial. 19411945. Lisboa: Notícias Editorial, 1997.

SANTIAGO, Silviano. Uma literatura nos trópicos - Ensaios sobre dependência cultural. São Paulo: Perspectiva, 1978.

SARTRE, Jean-Paul. Que é a literatura? São Paulo: Editora Ática, 2004.

SERRÃO, Joel (et alii). O Império Oriental (1660 - 1820), Tomo 2. Lisboa: Editorial Estampa, 2006. 
SILVA, Kelly Cristiane da.; SIMIÃO, Daniel Schroeter (Orgs.). Timor Leste por trás do palco. Cooperação internacional e dialética da formação do Estado. Belo Horizonte: Ed. UFMG, 2007.

SUBRAHMANYAM, Sanjay. O Império Asiático Português, 1500-1700. Uma história política e econômica. Tradução de Paulo Jorge Sousa Pinto. Lisboa: Difel-Difusão Editorial Ltda., 1995.

TAMAGNINI, Maria Isabel D. P. F. Diário de uma viagem a Timor (1882-1883). Porto: Fundação para a Ciência e a Tecnologia, 2002.

TAVARES, Manuel Viegas. Bua sei saren malus dikin loron ida. A integração dos timorenses na sociedade portuguesa. Lisboa: Instituto Piaget, 1999.

TAYLOR, John. Timor - a história oculta. São Paulo: Bertrand Brasil, 1993.

THOMAZ, Luís Filipe F. R. De Ceuta a Timor. Lisboa: Difusão Editorial S.A., 1994.

. Historia dos portugueses no Extremo Oriente. Macau e Timor, vols. I, II, III e IV. Lisboa: Fundação Oriente, 2000.

WATT, lan. A ascensão do romance. Tradução de Hildegard Feist. São Paulo: Companhia das Letras, 2007. 


\section{Anexos}

\section{A lenda do crocodilo}

Embora o presente trabalho analise apenas os textos produzidos em língua portuguesa por timorenses e por portugueses que viveram em Timor, as lendas têm valor privilegiado, por terem sido muito cedo traduzidas em língua portuguesa, como relatado, a exemplo de outras literaturas que tiveram seu início a partir da tradução dos textos literários de outros idiomas. São muitas lendas contadas oralmente até hoje.

O padre Artur Basílio de Sá transcreveu e traduziu diversas lendas timorenses. Relatando em seu livro a história da conquista de Timor e a separação do território entre holandeses e portugueses, ele iniciou a tradução das lendas timorenses do tétum-praça para o português. Além da lenda do Crocodilo, que tipifica a história de Timor, outras lendas encontram-se ali reproduzidas, perpetuando, assim, sua história e suas tradições.

Em estudo recente, intitulado Lendas e outras histórias de Timor (2007), Maria Cristiana Casimiro recolheu e publicou outras lendas, a partir do relato dos timorenses.

Neste trabalho, embora nos ocupemos apenas das produções escritas em língua portuguesa, vale apresentar um pouco do que chegou, em língua portuguesa, de lendas e contos de tradição oral. Boa parte dessa tradição continua viva nos ritos e mitos de Timor, nos rituais oficiados pelos liurais e chefes dos grupos timorenses.

Transcrevemos, a seguir, a lenda do Crocodilo, que, publicada por Basílio de Sá e também por Fernando Sylvan, têm várias versões, exemplificando a lealdade do povo timorense: 


\section{Timor despontou como as folhas do bétele, como o caule da arequeira}

Em tempos idos, lá para terras de Macaçar, um desolado crocodilo saiu do seu coito, com a mira de se alimentar.

Era Verão, pelo que os campos feneciam de aridez.

Perto dum coilão, onde o crocodilo vivia alapardado, ficava uma pequena e humilde povoação.

Para ali se dirigiu, indo colocar-se à sombra duma grande e velha árvore, à coca dum rafeiro vadio, dum porco, ou de qualquer cabrito descuidado.

Mas, por mais que se tivesse aproximado daquela desolada povoação, nada conseguiu lograr.

Regressou, pois, amargurado e faminto.

O Sol, que a sombra da velha árvore encobria, mitigando-lhe o ardor, ia já alto.

Quando, merencório, abandonou a frescura daquele sítio, era já meio-dia; fora, a terra escaldava; para chegar à foz da ribeira, ainda tinha muito que rastejar, e as margens eram só areia escaldante.

Então, tentou mover-se apressadamente; mas, a meio caminho, não podia sofrer mais, porque a areia queimava como fogo.

Arrastava-se penosamente, atormentado pela fome e por um calor infernal, sem que o refrigério duma nuvem passageira viesse reconfortá-lo.

O infeliz crocodilo gemia e contorcia-se, sentindo que a morte se aproximava.

A sua angústia era imensa!

Um rapazito, que por acaso passava perto, a tomar o seu banho, ouviu aqueles gemidos lancinantes.

Aproximou-se, solícito, para saber donde proviriam aqueles gritos.

Ao ver o pobre animal prestes a morrer, disse para consigo: "Coitado deste netinho crocodilo, uns minutos mais e morrerias!" água.

Tentou depois levantá-lo e, vendo que não pesava muito, transportou-o para a

O crocodilo, ao sentir-se de novo dentro de água, recobrou ânimo, exultando de satisfação, sem saber como agradecer ao seu salvador.

Mas, passados os primeiros momentos, disse, movido de gratidão: "De hoje em diante seremos grandes amigos. Ai do crocodilo que ousar molestar-te!... Desejando passear pelas ribeiras ou pelos mares, basta que me chames e digas: amigo, lembrate do bem que te fiz; e eu virei logo oferecer-te o meu dorso para viajares por onde te aprouver.

Se for do teu agrado, partiremos agora mesmo."

E, confiante, lá andou o rapazito a vogar, às costas do crocodilo, sendo já tarde quando voltou a casa.

Dali em diante, sempre que desejasse fazer-se ao mar, bastava-lhe chamar pelo amigo crocodilo, para que este aparecesse como por encanto. Foi assim durante muito tempo.

Mas um dia o crocodilo deslizou com o amigo para alto mar, e aí o seu instinto sentiu grande tentação.

Teve ganas de tragar o seu amigo.

Mas resistiu a tão feia tentação.

Resolveu aconselhar-se francamente com os peixes do mar e, por fim, também com um cachalote:

"A uma pessoa que nos valeu, devemos fazer bem ou mal?"

Mas esta resposta não lhe satisfez os instintos, e a saliva começava a crescerIhe na boca, embora no fundo do seu íntimo ele se esforçasse por resistir.

Consulta, então, todos os animais da terra, e todos respondem como os peixes.

Finalmente, deseja saber a opinião do macaco. estupefacto:

Este, pulando dum lugar para outro e arregalando muito os olhos, indaga 
"Que dizes tu?"

E o crocodilo repete o que dissera já aos outros animais.

Aqui o macaco pára, sentado num ramo, ao lado do crocodilo, e prega-lhe esta reprimenda mestra:

"Tu não tens vergonha?! Tu, a quem, um dia, estando prestes a morrer, à torreira do sol, este jovem desconhecido ergueu e transportou para o mar; tu queres agora, em paga, devorá-lo?!"

E, vituperando-o ainda mais por tão feio pensamento, aviltou-o quanto pôde e afastou-se para o cume da árvore.

O crocodilo, confuso e transido de vergonha, não pensou mais em devorar o seu grande amigo.

Mas, levando-o, um dia, em direcção ao Oriente, e entrando no mar de Timor, disse-lhe reconhecido:

"Meu bom amigo, o favor que me fizeste jamais o poderei pagar. Dentro em breve eu devo morrer; deves voltar para terra, tu, os teus filhos, todos os teus descendentes, e comer a minha carne em paga do bem que me fizeste."

Baseados nesta lenda, os velhos afirmam que a ilha de Timor, principiando em Lautém e acabando em Cupão, é esguia como o corpo dum crocodilo, e a parte central assemelha-se-lhe à barriga.

Timor quer dizer Oriente; muitos timorenses chamam ao crocodilo antepassado ou avô.

Se qualquer crocodilo devora alguém, é porque, dizem, este lhe fez ou disse algo de mal. Ou quando uma pessoa é apanhada por aquele, costuma gritar: Antepassado ou avô! Maldição! Maldição!

Quando entram ou passam uma ribeira onde haja crocodilos, costumam atar uma fita verde de folha de palmeira na cabeça, numa perna e, algumas vezes, também na mão e chamam para junto de si o cão. Assim, o crocodilo sabe, e não os morde.

(SÁ, 1961:12-22)

Essa lenda, que tipifica a estória do povo timorense, na versão transcrita pelo padre Artur Basílio de Sá, relata a lealdade e a simplicidade do povo perante situações desconhecidas, ainda que essas situações sejam provocadas por um "suposto" inimigo. A exemplo das fábulas da antiguidade, há a presença de animais que atuam na estória e imprimem-lhe um cunho moral. Os animais na estória repreendem o crocodilo, quando este quer devorar o amigo e, no final da estória, o crocodilo acaba vencendo sua batalha interna e a amizade é preservada.

Também transcrita por Fernando Sylvan, timorense que viveu em Portugal, a temática do sonho timorense é valorizada pelo autor, em outra versão da mesma lenda. Com Fernando Sylvan, já não existe mais o tom de fábula e há a simplicidade até na expressão formal do texto. Em outra versão, contida numa última recolha de contos orais timorenses, Maria Cristiana 
Casimiro enriqueceu a estória, acrescentando palavras em tétum e também acrescentando outros costumes à lenda.

Essa lenda caracteriza a existência do povo timorense, os contornos geográficos do país - semelhantes aos contornos do crocodilo -, os sentimentos de lealdade e a amizade entre dois seres de mundos diferentes. As lendas continuaram a propagar-se no decorrer dos tempos, paralelamente ao surgimento de outras manifestações literárias. É a partir da matriz cultural das lendas que Timor-Leste vai passar a elaborar sua identidade literária. 


\section{Literatura de viagem - Fragmentos}

\section{Gentio de Timor}

\section{III- Os desportos tradicionais}

(...) Os jogos de galo, pelo entusiasmo belicoso que despertam suscitando, por vezes, brigas rancorosas e sangrentas arruaças, estão apenas autorisados nas sedes das circunscrições e dos postos, e por ocasião dos bazares que se realisam, uma vez por semana, em dias diversos para cada um desses centros administrativos. (...) Debaixo do braço ou posto ao colo, não falta o galo de combate, nem no saquitel a lâmina acerada que, no começo dos torneios, se Ihe ata a uma das patas, apetrechando-o para uma peleja renhida, em volta da qual se há de comprimir o povoleu e ferverão as apostas a dinheiro.

Os jogos realizam-se em pleno largo, nas visinhanças da tranqueira da autoridade, e dentro de vedações de alvenaria ou rede de arame, afim de se evitarem mortes de espectadores entusiastas que se deixavam espetar pelas esporas, ás vezes envenenadas, dos combatentes.

É geralmente depois do meio dia que começa a função, quando se extinguiu a actividade mercantil dos bazares. Antes de se iniciarem as disputas, há já impaciência, vozearia, alvoroço, e um escarcéu de galos que cantam e batem as azas ruidosamente. Os donos empunham-nos, exibem-nos, fazemIhes o reclamo, e furam com eles por entre a gentana, para que todos os veja, Ihes aquilatem o valor e nenhum deles resista á tentação de apostar nas pugnas de que eles serão heróis. Os galos são colocados aos pares em frente uns dos outros, em ensaios que se repetem, variando de figurantes: experimenta-se a têmpera aguerrida de que eles dão logo mostras, enristando a crista, ouriçando as penas e desatando ás bicaradas. Combinados por fim os parceiros para cada uma das rixas que se vão travar, o borborinho aumenta, formulam-se opiniões anciosas, o publico apinha-se ainda mais, a esportular-se com as apostas, e ouvem-se bater as moedas contra as pedras, a ver se elas 
são ou não genuina ${ }^{40}$. Já de cócoras no meio do mercado, os donos dos contendores cofiam as penas dos palmípedes, ajustam-lhes as lâminas, aproximam-nos a desafiá-los, provocam-nos com palavras rascantes de incitamento, até que por fim os soltam, e o combate começa, ao som do berreiro de comentários do populacho. Os galos, primeiro, hesitam, ficam a medir se, escolhem posição, depois avançam e atacam-se pela frente e pelos lados, agridem-se com os bicos e com os esporões, saltam, voam, tomam outra vez balanço, e projectam-se em novas e mais certeiras e furiosas acometidas. Da coxa dum dos beligerantes já o sangue esparrinha. O outro, aos pinotes, não o larga. Atira-se-lhe para cima, cavalga-o, procura achata-lo contra o terreno, o seu bico, raivoso, remexe-se a arrancar-lhe um olho, a lâmina esfarpa-Ihe o ventre. Em vão, o rival procura defender-se. Dali a instantes, quando consegue desvencilhar-se, é para bater precipitadamente em retirada, indo agonisar contra a rêde da vedação. $O$ galo vitorioso planta-se no centro da pista, apruma o pescoço e ergue o seu canto apoteótico de triunfo...A assistência, enfrenesiada pelas sensações fortes do jogo, parece agora atacada de loucura. Há pulos desvairados, gritos selvagens de alegria, discussões azedas levantadas por alguns que não souberam prever o desfecho da pendência, e que se vêem agora falhados nos seus cálculos e defraudados nos seus ricos cabedais... ${ }^{41}$

\footnotetext{
40 Timor está inundado de moeda falsa, sobretudo desde 1929. É o quebra-cabeças dos cobradores de imposto e a aflição dos indígenas, e um problema que tem de ser solucionado sem mais delongas.

${ }^{41}$ A fuga dum galo, mesmo vencedor, ante o adversário, vale como um sinal de rendição. Quando um timorense vê o seu galo fraquejar, intervem, sob pretexto de lhe concertar a lamina, que diz desapertada, mas, de facto, para Ihe deixar tomar fôlego. Uma perna do galo vencido é para "o comandante do quartel" (em Bobonaro, para os soldados do esquadrão), e por cada jogo pagam os organisadores uma taxa de 20 avos, que entra nos cofres das Administrações locaes.
} 


\section{Capítulo I}

\section{Primeira noite}

Pulo-Cambing é uma pequenina ilha do arquipélago malaio: cume de velha montanha que submergiu outrora, vestígio ultimo de um mundo imerso que a água azul cobriu um dia, talvez para nunca mais voltar a sentir-se batido pelo sol dos trópicos e pelas ondas do Índico e do Pacífico dominadores.

Pulo-Cambing (I), na sua pequenez, é uma ilhazinha que a três milhas de distância cabe nos círculos dos binóculos. Vista de Timor é, como todas as ilhas miniaturais do arquipélago, uma mancha na infinidade oceânica. Recorda, às vezes, certos desenhos à pena dos antigos artistas nipônicos e paisagens chinesas dos "painneaux" em varetas de bambu.

(I) - Pulo-Cambing não mede sequer uma centena de quilômetros quadrados. Situada á frente de Díli, fica entre as ilhas de Timor, Ombai e Wetter, na margem norte, portanto, do Estreito de Sonda. O seu nome, de origem malaia, significa: llha dos Carneiros. Tem também a designação portuguesa de Ataúro.

(BRAGA, Paulo. Ilha dos homens nus. In: Cadernos Coloniais. Lisboa: Editorial Cosmos, 1936, p.3)

"A minha primeira impressão de Timor, no desembarque em Díli, foi a de que pisava de novo a terra da Índia do Concão, a Índia dos palmares.

A mesma cor vermelha do solo, aqui de xistos e suas argilas, lá de laterites, a mesma flora, a mesma tez da gente. Apenas aqui mais nacarada a luz mais docemente aproximada do sonho dos homens." (CASTRO, Alberto Osório de. Ilha verde e vermelha de Timor. Lisboa: 1996, p.20. ${ }^{42}$ )

"A breve fauna de Timor não é já, pode dizer-se, a da índia, como é a de Samatra, da Península Malaia, a de Java, mas a da Austrália vizinha, tão diversa. Nem falta em Timor um canguru, a pequena 'méda'." (idem, p.21)

\footnotetext{
42 Publicado anteriormente em forma de livro em 1943. Na revista Seara Nova, foi lançado em formato folhetim entre 1928 e 1929.
} 


\section{Cronologia histórica de Timor Antes da chegada dos portugueses}

Alguns achados arqueológicos permitem supor que a ilha fosse povoada desde - Paleolítico por espécies anteriores ao homo sapiens. No Neolítico, a civilização do machado oval foi introduzida pela raça papua-melanésia. Aproximadamente em 2.500 a.C., surge a civilização neolítica mais avançada, com a raça proto-malaia, a que parece remontar à atual cultura timorense. Houve, depois, outras vagas de povos, registrando-se influências indianas e chinesas. A influência mais nítida, contudo, foi a malaia, fazendo-se sentir na língua, no traje, na culinária e nas técnicas de navegação e pesca dos povos ribeirinhos.

\section{2-1514}

É incerta a data da chegada dos portugueses a Timor. Terá, possivelmente, ocorrido durante a expedição da armada do vice-rei da Índia, Afonso de Albuquerque, que conquistou Malaca (1511) e as Ilhas Molucas (1512-1515). Timor figura nos mapas do piloto-cartógrafo Francisco Rodrigues desenhados em 1512. Em 1514, escrevendo de Malaca, Rui de Brito informa que Timor, ilha além de Java, tem muito sândalo, mel e cera. Nos anos seguintes, a ilha foi visitada por naus portuguesas para buscar sândalo. Os portugueses limitam-se, numa primeira fase, a frequentar sazonalmente as costas, a comercializar sândalo.

1514 - Os portugueses chegam a Timor, depois de terem conquistado Malaca em 1511, estabelecendo-se na parte oriental da ilha.

1769 - Após terem desenvolvido intensa atividade missionária desde metade do século XVII, os portugueses instalam a capital de Timor-Leste em Díli. A presença portuguesa notar-se-á sempre mais no litoral do que no interior da ilha, onde se mantêm formas tradicionais de organização assentes no papel dos chefes locais, designados por liurais ou régulos. 
1887 - O liurai D. Boaventura de Manufai comanda uma importante revolta contra o domínio português.

1912 - Os rebeldes de Manufai são bombardeados pelo cruzador português Pátria, resultando deste ataque cerca de 3 mil mortos. Inicia-se uma forma mais moderna de colonização do território e é fundada a Sociedade Agrícola Pátria e Trabalho.

1926 - Com a instauração da ditadura em Portugal, começam a ser enviados com regularidade para Timor-Leste cidadãos portugueses que se opõem ao regime de Salazar.

1942 - Forças japonesas invadem o território de Timor-Leste em 20 de fevereiro, destruindo edifícios e plantações, saqueando casas, matando homens e violando mulheres. Cerca de 400 australianos, apoiados por timorenses e por algumas dezenas de deportados portugueses, resistem ao invasor, sobretudo nas montanhas, reduto tradicional da resistência em Timor. Da ocupação japonesa, resulta a morte de mais de 50 mil homens.

1945 - Derrotado o Japão e as restantes potências do Eixo (Alemanha e Itália), os Aliados devolvem Timor-Leste a Portugal. Neste mesmo ano, as Índias Orientais Holandesas tornam-se independentes, com o nome de Indonésia.

1974 - O Movimento das Forças Armadas derruba, em 25 de abril, a ditadura instalada no poder há 48 anos. São fundados, em Timor-Leste, os partidos FRETILIN (Frente Revolucionária Timor-Leste) (que começou por se chamar ASDT - Associação Social-Democrática Timorense), UDT (União Democrática Timorense) e APODETI, que se propõem a disputar em eleições livres a liderança política do território.

1975 - A FRETILIN ganha, com 55\% dos votos, as eleições em Timor-Leste. A UDT, apoiada pelos militares indonésios, lança um golpe em Díli. O golpe falha, e a FRETILIN toma o poder na capital, proclamando, em 28 de novembro, a independência da República Democrática de Timor-Leste. Inicia-se um período 
de guerra civil que leva à invasão, em 7 de dezembro deste ano, do território pelas forças indonésias e à retirada das tropas portuguesas para a ilha de Ataúro, em 8 de dezembro.

1976 - A Indonésia anexa, em 17 de julho, Timor-Leste, passando a consideralo a sua $27 \underline{\underline{a}}$ província. Como resultado da guerra civil e da invasão, registramse cerca de 100 mil mortos.

1977 - A Assembleia-Geral da ONU rejeita a anexação do território pela Indonésia e pronuncia-se pela maioria a favor da autodeterminação.

1978 - O governo australiano reconhece, em janeiro, a integração de TimorLeste no território da Indonésia.

1979 - A Assembleia da ONU condena novamente a anexação do Timor-Leste.

1980 - Xanana Gusmão é escolhido para liderar as FALINTIL, forças armadas da FRETILIN.

1981 - É divulgado o relatório enviado a Suharto, presidente da Indonésia, no qual são relatadas torturas exercidas contra os timorenses.

1982 - O bispo D. Agostinho da Costa Lopes denuncia o massacre de cerca de 500 timorenses por militares indonésios em Lacluta. $O$ papa afirma que 0 Vaticano não reconhece Timor-Leste como província indonésia. O presidente Ramalho Eanes defende a criação de uma frente comum dos países de língua oficial portuguesa contra a ocupação indonésia.

1983 - A Comissão de Direitos do Homem da ONU condena a violação dos direitos e liberdades dos Timorenses. Em agosto deste ano, mais de duas centenas de pessoas são mortas perto de Viqueque. É proclamado pelos indonésios o estado de emergência. 
1986 - O governador Mário Carrascalão revela que, desde 1975, morreram mais de 100 mil timorenses. Pela primeira vez, o Parlamento Europeu, em Estrasburgo, condena a ocupação indonésia e defende a autodeterminação do Timor-Leste.

1988 - É criado o Conselho Nacional de Resistência Timorense, presidido por Xanana Gusmão. Os países que então integravam a Comunidade Económica Europeia defendem uma posição favorável à autodeterminação do território.

1989 - O bispo D. Ximenes Belo escreve ao secretário-geral da ONU, solicitando a realização de um referendo sobre o futuro do território. Milhares de timorenses continuam a ser presos e assassinados.

1991 - Em Díli, em 12 de novembro, 271 pessoas são mortas no cemitério de Santa Cruz pelas tropas indonésias quando se preparavam para depor flores na campa de um militante da independência, assassinado semanas antes. As imagens recolhidas por operadoras de televisão correm o mundo e provocam uma grande onda de indignação.

1992 - Em 20 de novembro, Xanana Gusmão é preso pelas tropas indonésias.

1993 - Xanana Gusmão é condenado, no dia 21 de maio, em Jacarta, à prisão perpétua, que será comutada em 20 anos.

1994 - Um grupo de estudantes timorenses invade a Embaixada dos Estados Unidos em Jacarta, durante a visita do presidente Bill Clinton, exigindo a libertação de Xanana Gusmão e a investigação dos crimes praticados pelas tropas indonésias.

1995 - Começam, em Genebra, com o apoio da ONU, conversações entre os governos de Portugal e da Indonésia.

1996 - D. Ximenes Belo e Ramos-Horta são distinguidos com o Prêmio Nobel da Paz. O secretário-geral da ONU, Kofi Annan, nomeia um representante 
pessoal para as questões de Timor-Leste. D. Basílio do Nascimento é consagrado bispo de Baucau.

1997 - Nelson Mandela, durante visita a Jacarta, avista-se com Xanana Gusmão na prisão de Cipinang.

1998 - Ao fim de 30 anos de ditadura pessoal, o general Suharto é substituído por Habibie na presidência da Indonésia. Lisboa e Jacarta abrem seções de interesses nas capitais opostas. Começam a se organizar milícias antiindependência com o apoio dos militares indonésios.

1999 - Habibie anuncia a intenção de promover um referendo sobre o futuro do território. Xanana Gusmão é deslocado de Cipinang para uma residência onde permanecerá em prisão domiciliar. O referendo, com uma participação de $98,6 \%$ dos eleitores, realiza-se em 30 de agosto, tendo cerca de $80 \%(78,9 \%)$ dos votantes escolhido o caminho da independência. Os resultados são divulgados em 4 de setembro. Nos dias que se seguem à divulgação dos resultados pelo secretário-geral da ONU, começam os massacres que originam uma onda de indignação em todo o mundo, da qual resultará uma cadeia de solidariedade até então nunca vista em Portugal. Em 19 de setembro, as forças da INTERFET - Força Internacional para o Timor-Leste, compostas por australianos, neozelandeses, tailandeses e britânicos - desembarcam em Díli, por decisão unânime do Conselho de Segurança da ONU. Em Genebra, por 32 votos contra 12, é tomada a decisão de se criar uma comissão de inquérito sobre os crimes praticados pelos militares indonésios e pelas milícias. O bispo D. Ximenes Belo visita Portugal e recebe, em várias cidades, impressionantes manifestações de solidariedade. Em 29 de setembro, chega a Lisboa 0 comandante Xanana Gusmão, que permanece na capital portuguesa por três dias, testemunhando a imensa solidariedade dos portugueses. 


\section{Timor - Alguns dados importantes}

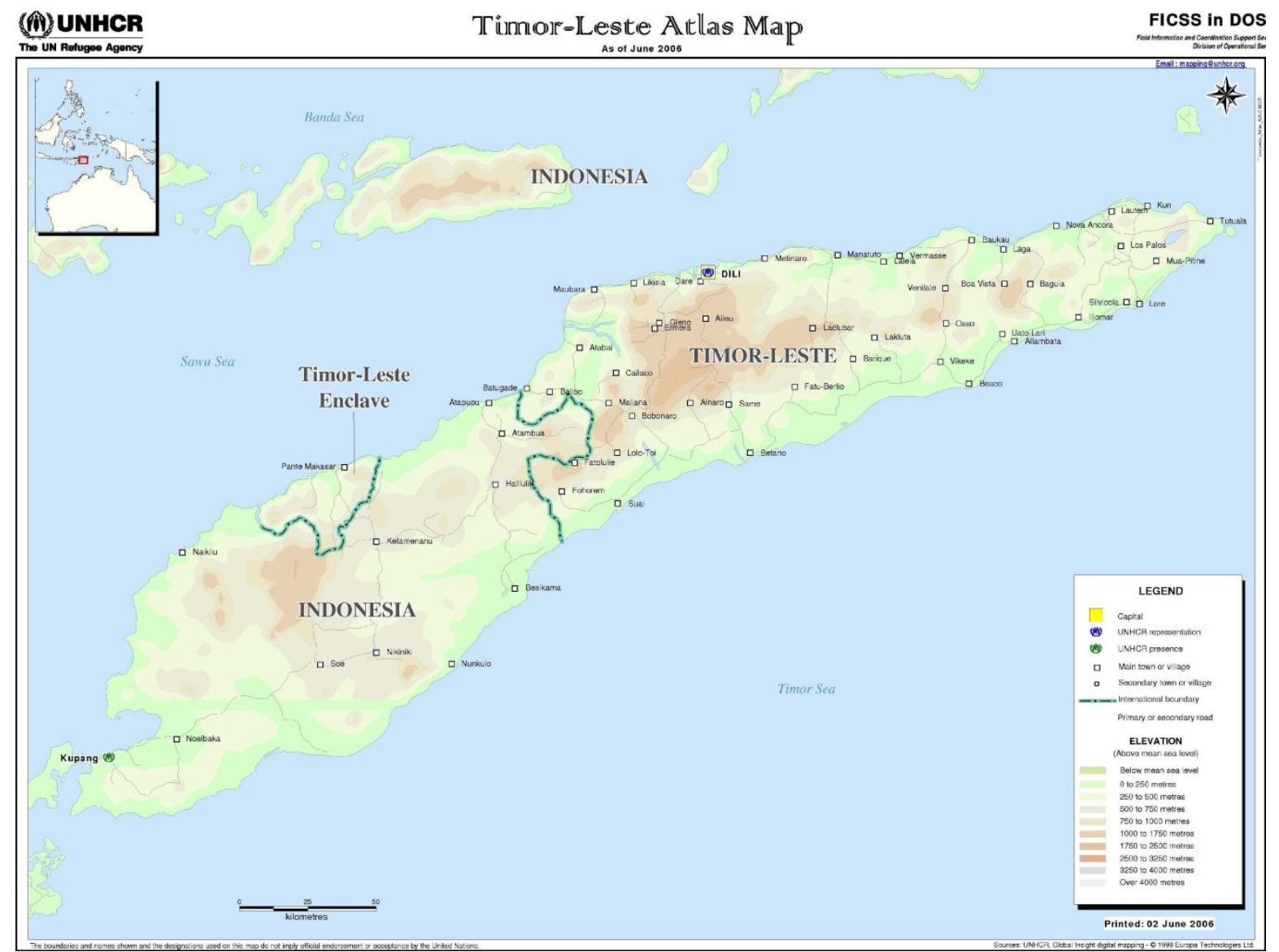

Localização: hemisfério sul, entre os paralelos $6^{\circ}$ e $1^{\circ} \stackrel{\text { sul, }}{\text { e entre os }}$ meridianos de $123^{\circ}$ e $128^{\circ}$ este leste de Greenwich.

Capital: Díli, situada na costa norte da ilha.

População: em 1974, cerca de 700 mil habitantes; em 1999, mais de 800 mil habitantes; cerca de 200 mil mortos durante 24 anos de ocupação indonésia; atualmente, cerca de 1 milhão de habitantes (censo de 2010).

Extensão: 18.989 km² (Timor-Leste); 13.380 km (Timor Ocidental, território pertencente à República Indonésia). Assim, dois espaços políticoadministrativos, internacionalmente reconhecidos, existem na ilha: um, o de Timor Ocidental, integrado como parcela das antigas Índias Holandesas, na 
República da Indonésia; o outro, o de Timor-Leste, que abrange a parte oriental de Timor, também o enclave de Oé-Cussi, sobre a costa setentrional da parte ocidental de Timor, e ainda dois ilhéus próximos, o Ataúro e o Jaco, constituindo Timor Leste ${ }^{43}$ (Marcos, 1995:21).

Línguas principais: tétum, português e malaio. Depois de 1975, o ocupante indonésio impôs a sua língua, o "bahasa indonésia". Timor-Leste, desde o princípio, abrigava vários povos que falavam línguas distintas. De fato, embora hoje tenhamos o tétum como língua unificadora em Timor-Leste, há também os idiomas locais falados por esses povos, conforme suas regiões, denominadas como dato ou suco. Desses idiomas, podemos citar fataluco, macalere, macassae, mídic e búnac (ADÃO apud THOMAZ, 2002).

Estrutura tradicional: divisão do território em reinos ou "regulados", governados por liurai, reis ou régulos. Cada um dos reinos ou "regulados" era constituído por "sucos", que incluíam várias aldeias designadas por "leo", "knusa", "lissa" ou"lil", conforme os idiomas locais. À frente de cada "suco" estava um "dato", do qual dependiam todos os chefes das povoações, também conhecidos por "tumungões". Timor-Leste chegou a ser dividido em 46 reinos ou "regulados". Parte dessa estrutura tradicional mantém-se em vigor.

Produções principais e riquezas naturais: café, borracha, copra, cacau, petróleo, mármore e madeiras exóticas, sobretudo o sândalo.

Religião: Maioria, aproximadamente $90 \%$ católicos, algumas comunidades de protestantes e muçulmanos.

\footnotetext{
${ }^{43}$ Referência geográfica de Artur Marcos em Timor timorense com suas línguas, literaturas, Iusofonia (1995).
} 


\section{Regiões de Timor}

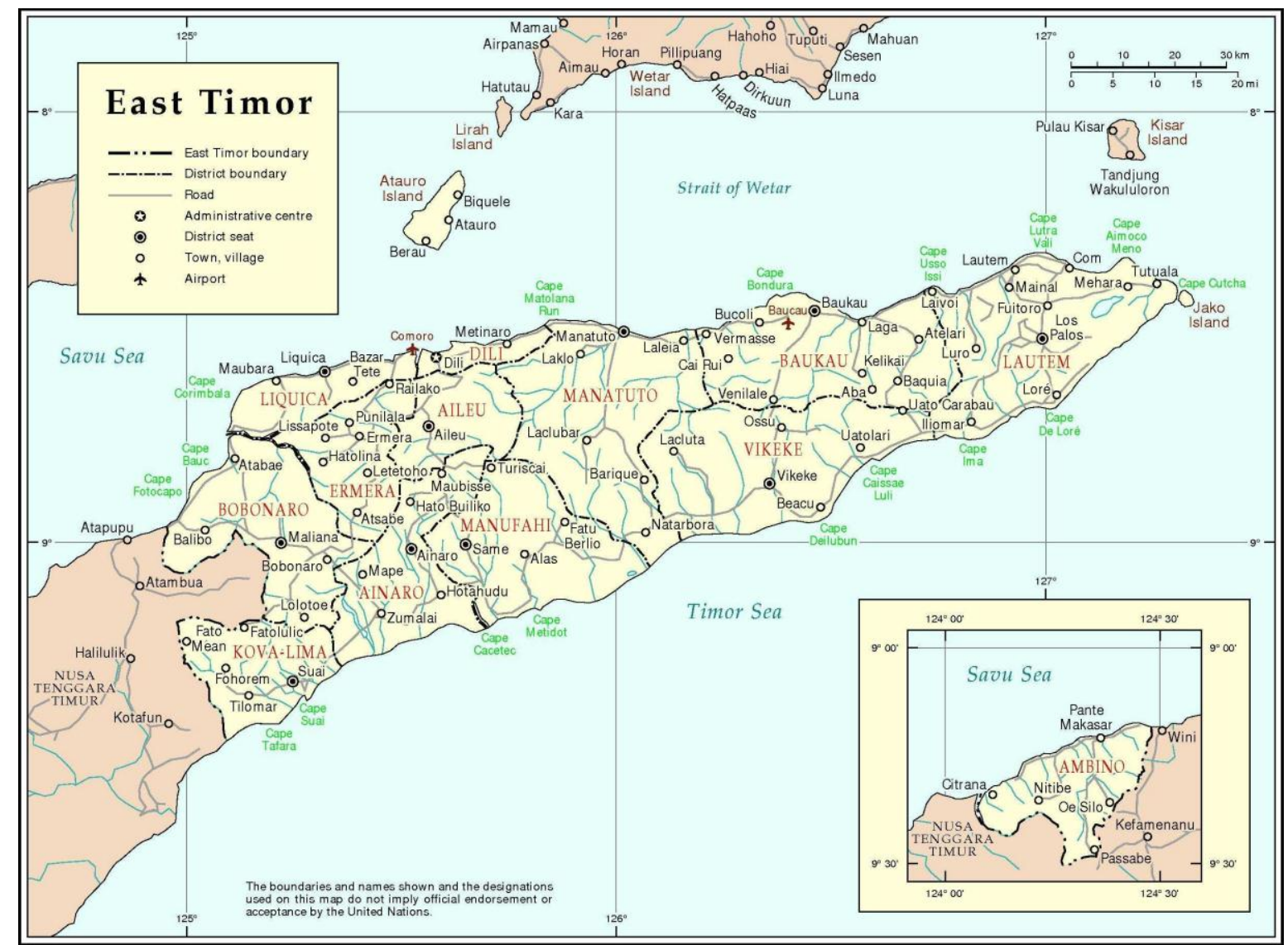

Map No.4111 UNITED NaTiONS
May 1999

Department of Public intormation
Cartographic Section 


\section{Mapas dos descobrimentos no Extremo Oriente}

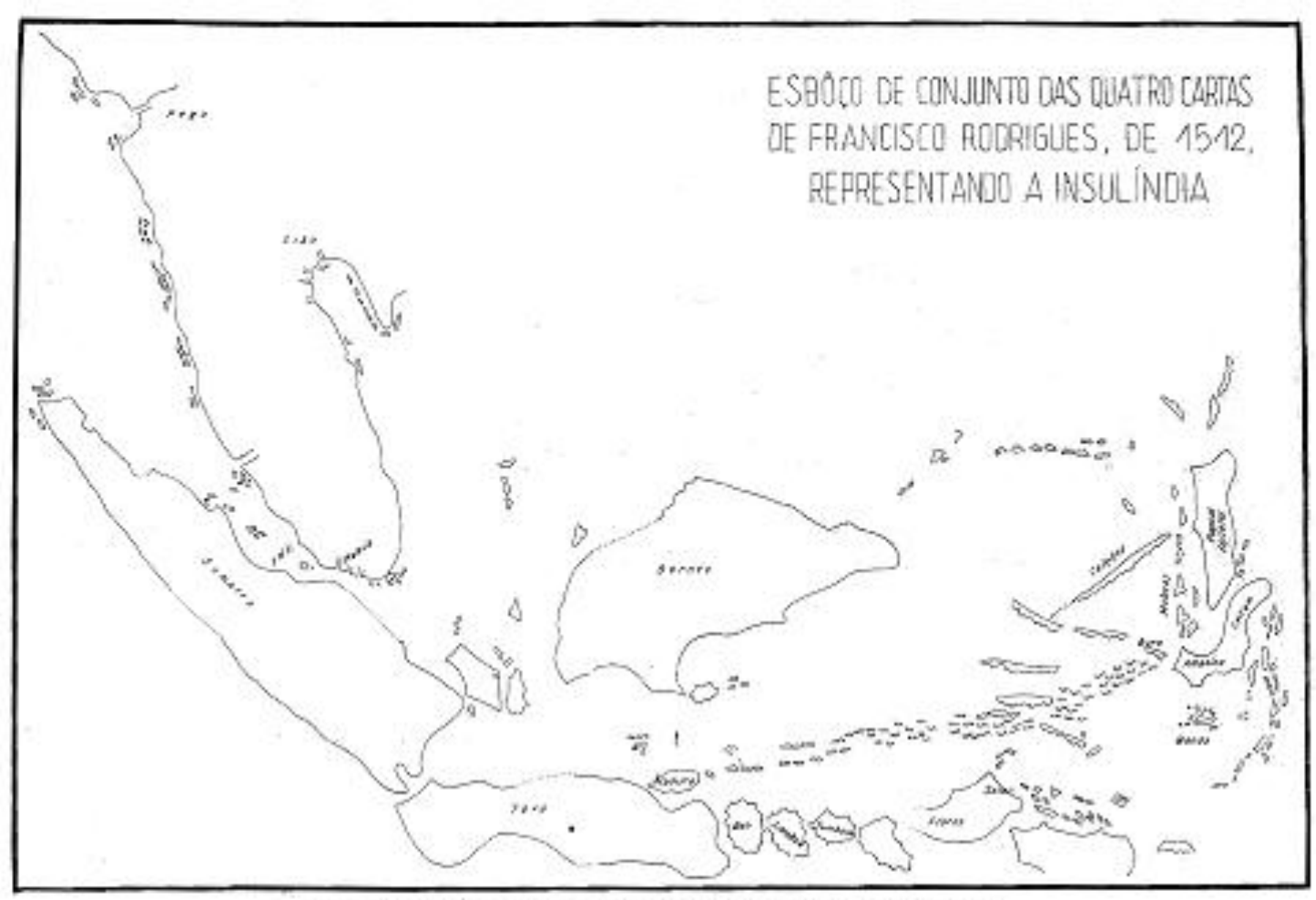

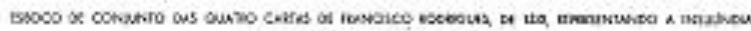

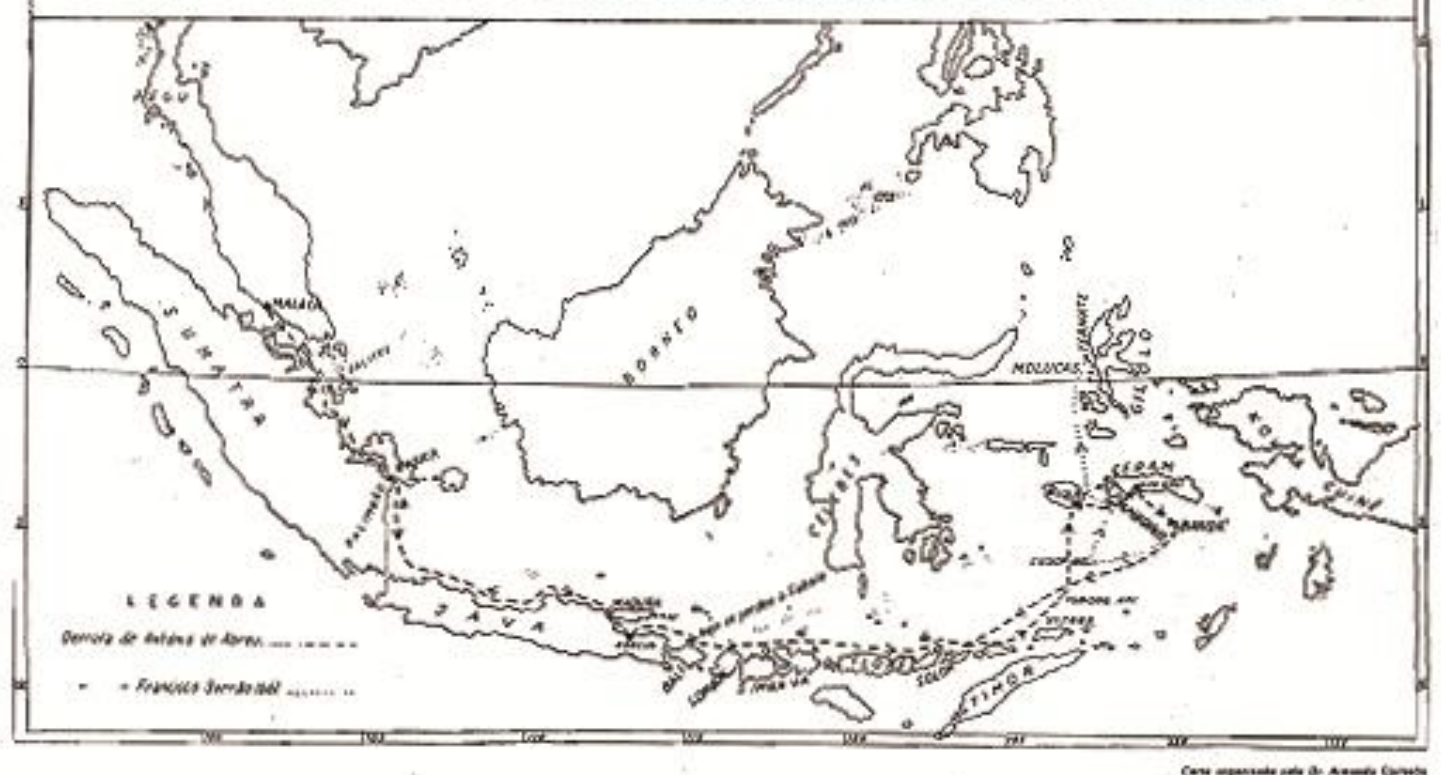

